\title{
LAS PLANTAS AROMÁTICAS COMO ALTERNATIVA DE SOSTENIBILIDAD AMBIENTAL Y DESARROLLO RURAL
}

Dra. Graciela Chalela A. 


\section{UNIVERSIDAD AUTÓNOMA DE BUCARAMANGA}

LAS PLANTAS AROMÁTICAS

Como alternativa de sostenibilidad ambiental y desarrollo rural

Dra. Graciela Chalela A.

ISBN 978-958-8166-78-0

\section{ALBERTO MONTOYA PUYANA}

Rector

GILBERTO RAMÍREZ VALBUENA

Vicerrector administrativo y financiero

\section{EULALIA GARCÍA BELTRÁN}

Vicerrectora Académica

MIGUEL ÁNGEL HERNÁNDEZ

Director de Investigaciones

LA BASTILLA

Diagramación e impresión

Publicaciones UNAB

Producción

Universidad Autónoma de Bucaramanga

Avenida 42 № 48 -11

Bucaramanga, Colombia

www.unab.edu.co

Las opiniones contenidas en esta obra, no vinculan la institución, sino que son exclusiva

responsabilidad de los autores, dentro de los principios democráticos de la cátedra libre y la libertad de expresión consagrados en el artículo 3 del Estatuto General de la Corporación

Universidad Autónoma de Bucaramanga. El material esta publicación no puede ser

reproducido sin autorización previa

\section{AGRADECIMIENTOS A:}

- Audy Mogotocoro Capacho, Tecnóloga en Agrobiotecnología para el Desarrollo Sostenible

\section{- Grupo UNAB Ambiental - Cinbbya}

por su valiosa colaboración y participación 


\section{PRÓLOGO}

S egún la organización de estados iberoamericanos para la educación, la ciencia y la cultura (OEI), el desarrollo rural persigue dar respuesta a tres necesidades básicas para hacer posible un futuro sostenible:

- Mejorar la formación y el bienestar de aquellas personas que viven en medios rurales (cerca de la mitad de la población mundial), erradicando la pobreza extrema y evitando su migración hacia la marginación de la periferia de las ciudades.

- Lograr una producción agrícola sostenible para asegurar que todos los seres humanos tengan acceso a los alimentos que necesitan y

- Proteger y conservar la capacidad de la base de recursos naturales para seguir proporcionando servicios de producción, ambientales y culturales.

Todos los grandes retos a los que se enfrenta hoy la humanidad para avanzar hacia el logro de un futuro sostenible -ya sea erradicar la pobreza extrema y el hambre, conseguir la educación universal, la igualdad entre los géneros, reducir la pérdida de biodiversidad y otros recursos medioambientales, etc., exigen una atención prioritaria al desarrollo rural. De hecho la necesidad del desarrollo rural se asocia, habitualmente, a la existencia de graves problemas que afectan a quienes viven en este medio, particularmente en los países en desarrollo, pero también en los países llamados desarrollados.
Es bien conocido que las zonas rurales son el hogar de la mayoría de los pobres del planeta, de quienes viven con menos de un dólar diario, de quienes carecen de sistemas sanitarios e incluso de agua potable; de quienes son más vulnerables a los fenómenos atmosféricos extremos como inundaciones o sequías que llegan a provocar grandes hambrunas; cuatro de cada cinco de los más de 172 millones de niños y niñas sin escolarizar en el mundo, viven en áreas rurales, con fuertes discriminaciones hacia las niñas; y la gran mayoría de los cerca de 800 millones de analfabetos, jóvenes o adultos, pertenecen al mundo rural (UNESCO, 2010). $Y$ es en este medio donde son más fuertes las discriminaciones hacia las mujeres, que muchas veces deben asumir el papel de cabeza de hogar y además el de ser desplazadas por diversas causas.

Dicho de otro modo, en el medio rural de los países del llamado Tercer Mundo son conculcados los derechos socioeconómicos más básicos (a la educación, a la atención médica, a viviendas dignas provistas de sistemas sanitarios, a un trabajo regulado y debidamente remunerado, al descanso...), además de los derechos democráticos, impidiendo la participación ciudadana en la toma de decisiones. Las condiciones de vida son tan duras que impulsan migraciones masivas hacia las ciudades o, mejor dicho, hacia sus periferias de chabolismo y marginación, generando nuevos y graves problemas.

Por otra parte, es obvio que la situación en el campo se ve afectada por hechos que tienen un origen en buena parte externo, como ocurre con la necesidad de nuevos recursos energéticos para el 
transporte, que impulsa la producción de biocombustibles. Particular incidencia tiene el modelo alimentario que se ha generalizado en los países "desarrollados", que pone en peligro al conjunto de la población mundial (Bovet et al., 2008). Un modelo que está sobreexplotando y agotando recursos tan esenciales como el agua o el suelo cultivable, pues está caracterizado, entre otros, por:

- Una agricultura intensiva que contribuye a la tala de árboles para aumentar la superficie cultivable, extiende los monocultivos marginando miles de variedades vegetales y utiliza grandes cantidades de abonos y pesticidas contaminantes que producen profundos cambios antropogénicos en la cubierta del suelo, degradándolo y poniendo en peligro la biodiversidad y a la propia especie humana. Una agricultura intensiva que recurre además al transporte por avión de productos fuera de estación, contribuyendo notablemente al crecimiento de las emisiones de $\mathrm{CO} 2$.

- La inversión de la relación vegetal/animal en las fuentes de proteínas, con fuerte caída del consumo de cereales y leguminosas y correspondiente aumento del consumo de carnes, productos lácteos, grasas y azúcares. Se trata de una opción de muy baja eficiencia porque, como muestran los análisis, para obtener 1 kilo de carne se necesitan 900 kilos de alimentos vegetales, 16000 litros de agua y un consumo de energía tan elevado que la industria de la carne es responsable de más emisiones de $\mathrm{CO} 2$ que la totalidad del transporte.

- La refinación de numerosos productos (azúcares, aceites...), con la consiguiente pérdida de componentes esenciales como vitaminas, fibras, minerales, con graves consecuencias para la salud.
A ello habría que añadir la reciente transformación de extensas zonas de cultivo para la producción de agrocombustibles, utilizando maíz, soja, etc., que eran destinados al consumo humano y provocando deforestaciones para contar con nuevas superficies de cultivo, contribuyendo además al incremento del precio de los alimentos. Y no podemos olvidar el creciente desarrollo de la agricultura industrial, con sus semillas patentadas (que los campesinos se ven obligados a comprar cada vez) y el uso de transgénicos sin atender debidamente al principio de precaución, con graves repercusiones: pérdida de biodiversidad, degradación de los ecosistemas y hundimiento de la agricultura artesanal. En definitiva, a medida que la agricultura se ha ido transformando, bajo la presión de las sociedades consumistas, se ha convertido en un problema para el medio ambiente, al emitir carbono en vez de almacenarlo, al facilitar las inundaciones más que ayudar a impedirlas, y al destruir más que proteger la biodiversidad (Halweil, 2002). La agricultura industrializada se ha convertido así en un serio obstáculo para la soberanía alimentaria de los pueblos, es decir, para su derecho a definir sus propias políticas sustentables de producción, distribución y consumo de alimentos, garantizando el derecho a la alimentación para toda la población (Fernández Such, 2006).

A todo ello hay que añadir que, según informes de la FAO de 2013 "Pérdidas y desperdicio de alimentos en el mundo" y "La huella del desperdicio de alimentos: impactos en los recursos naturales", alrededor de un tercio de la producción de los alimentos destinados al consumo humano se pierde o desperdicia en todo el mundo, lo que equivale a aproximadamente 1300 millones de toneladas al año. Esta cifra de alimentos que se desperdician anualmente no solo provoca grandes pérdidas económicas, sino también un grave daño a los recursos naturales de los que la humanidad depende para alimentarse. "La huella del desperdicio de alimentos: impactos en los recursos naturales" es el primer estudio que analiza los efectos del despilfarro alimentario a nivel mundial desde una perspectiva 
medioambiental, centrándose de forma específica en sus consecuencias para el clima, el uso del agua y el suelo y la biodiversidad. Entre sus principales conclusiones destacan que cada año los alimentos que producimos pero luego no comemos consumen un volumen de agua equivalente al caudal anual del río Magdalena y son responsables de añadir 3300 millones de toneladas de gases de efecto invernadero a la atmósfera del planeta.

Con este manual resultado de la capacitación impartida por UNAB Ambiental de la Universidad Autónoma de Bucaramanga a mujeres rurales de Lebrija (Santander) dentro de su proyecto de investigación denominado "Implementar una biohuerta piloto de plantas medicinales para la creación de una asociación de mujeres campesinas cabeza de hogar como alternativa de sostenibilidad ambiental y desarrollo rural" se pretende cambiar la visión de la pobreza, hacer que las personas objeto de la capacitación crean que son capaces de sobrevivir dignamente, que pueden ayudar a otras, que pueden sacar de la tierra sus mejores frutos y que al asociarse por medio de cooperativas puedan mirar un futuro mejor para sus familias y que las plantas medicinales y aromáticas por ejemplo, pueden servir de sustento si se manejan de manera adecuada y sin intermediarios.

El fundamento de la Nueva Cultura Rural según la OEI, puede resumirse en los siguientes 10 puntos:

1. Hacer posible el protagonismo del mundo rural y valorar su papel en la conservación de la Naturaleza.

2. Fomentar una economía multifuncional como medio para fijar población.

3. Conservar y transmitir lo que tiene de valioso su tradición oral y empírica.
4. Adecuarse a los nuevos modelos de gobernanza y gestión patrimonial y económica.

5. Crear una cultura de consumo local.

6. Abrir el debate sobre la definición de una Nueva Cultura ante los cambios y transformaciones del mundo rural y los desafíos del cambio climático.

7. Estudiar estrategias para asimilar a los nuevos pobladores dentro de un contexto de identidad y coherente.

8. Propiciar recursos formativos y de gestión para una economía sostenible.

9. Trasladar los valores y la importancia del mundo rural a la sociedad urbana.

10. El futuro está en el campo.

Dra. Graciela Chalela A. Directora Unab Ambiental-CINBBYA Directora proyecto 2016

oraly empirica. 


\section{CONTENIDO}

\section{CAPÍTULO 1}

1. Las Plantas. .7

2. Clasificación de las Plantas.

.8

3. Plantas aromáticas

4. Plantas medicinales.

5. Hortalizas

6. Verduras

\section{CAPÍTULO 2}

1. Preparación del suelo para la siembra.

\section{CAPÍTULO 3}

1. Huerta orgánica. .27

2. Huerta urbana. .29

3. Compostaje. 31

4. Preparados fitoterapéuticos

\section{CAPÍTULO 4}

1. Biotecnología y bioproceso ................................................41

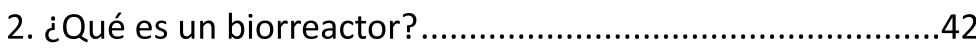

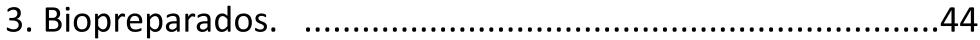

4. Elaboración de biopreparados ..........................................46

5. Biopreparados de uso doméstico ...................................47

\section{CAPÍTULO 5}

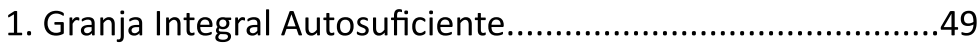

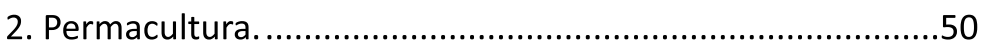

\section{CAPÍTULO 6}

1. Asociatividad.

GLOSARIO 


\section{CAPÍTULO 1.}

\section{LAS PLANTAS}

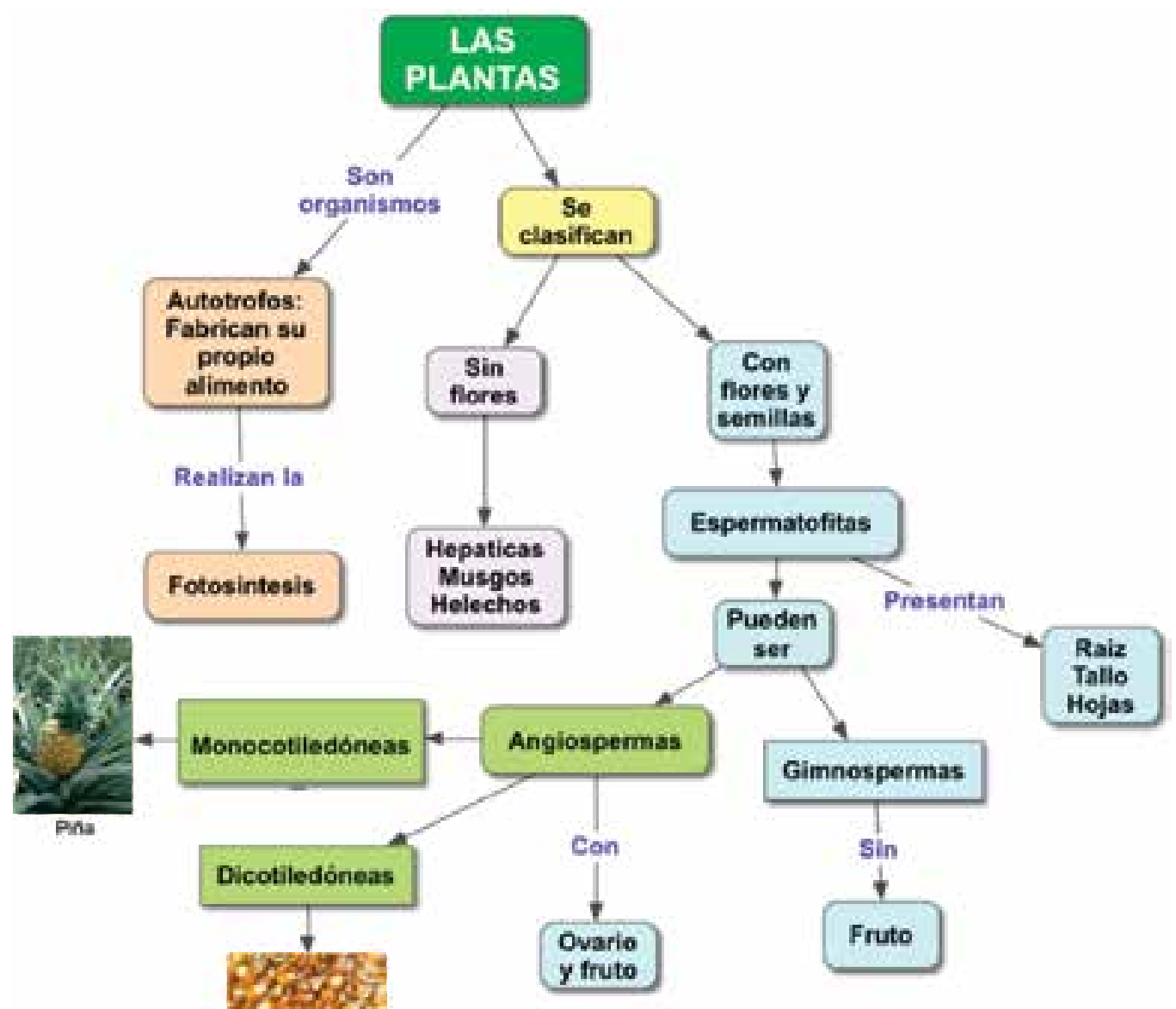

Figura 1. Clasificación de las plantas.

Fuente: Chalela A. G. Diagrama propio.- Unab Ambiental

Las plantas son seres vivientes que como los animales se alimentan, respiran y se reproducen. A diferencia de los animales, las plantas no pueden desplazarse, ni tampoco sentir. Pero sí pueden hacer algo que los animales no hacen: fabricar su propio alimento mediante la fotosíntesis. Proceso que ocurre en las plantas durante el día, mediada por la luz del sol y transformada por los cloroplastos. 


\section{Partes de una planta (Angiosperma)}

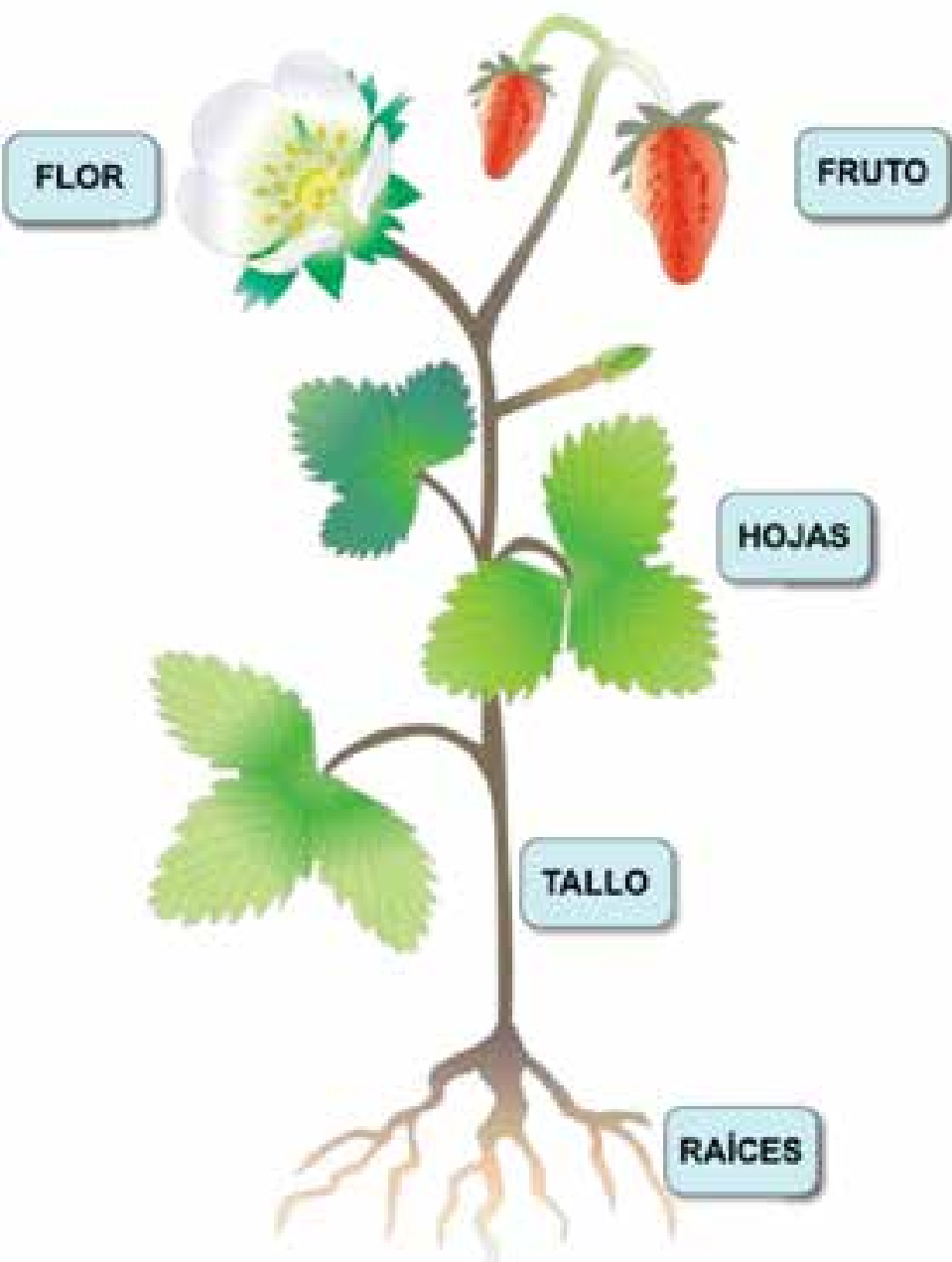

PARTES DE UNA PLANTA

Figura 2. Partes de una planta angiosperma.

Fuente. Chalela A. G. Diagrama propio-Unab Ambiental

\section{CLASIFICACIÓN DE LAS PLANTAS}

Las plantas brindan diferentes utilidades a los seres humanos y de acuerdo con éstas se las ha clasificado en:

Alimenticias: Como Cereales: Arroz, Trigo, Centeno. Hortalizas: Lechugas, Tomate, Acelga, Legumbres: Arveja, Fríjol, Habas, Frutas: Piña, Durazno, Banano.

Aromáticas: Son aquellas que tienen hojas o flores, que desprenden un aroma más o menos intenso. Puede ser un árbol (Naranjo amargo por sus flores), un arbusto (Rosal) o una planta herbácea (Lavanda).

Condimentarias o culinarias: Son aquellas que se usan en la cocina, para condimentar guisos, sopas, ensaladas, postres y salsas.

Las hierbas más habituales para esto son: Albahaca, Laurel (no es una Hierba, es un arbusto), Menta, Orégano, Perejil, Romero (es otro arbusto), Salvia, Tomillo, etc. La mayoría de Plantas Condimentarias son también Plantas Aromáticas.

Medicinales: Son aquellas que tienen propiedades curativas en alguna de sus partes (hojas, flores, semillas, raíces, etc.) y sirven para calmar, combatir o incluso, curar enfermedades. Hay miles de especies que se pueden considerar medicinales, tanto árboles, arbustos como herbáceas. Se dice, que todas las plantas pueden tener propiedades medicinales por alguna razón u otra. Se usan en forma de infusiones, cataplasmas, etc.

Brindan alivio o curan algún tipo de dolencia como: Toronjil. La hierba Luisa. El Cidrón y la manzanilla. 

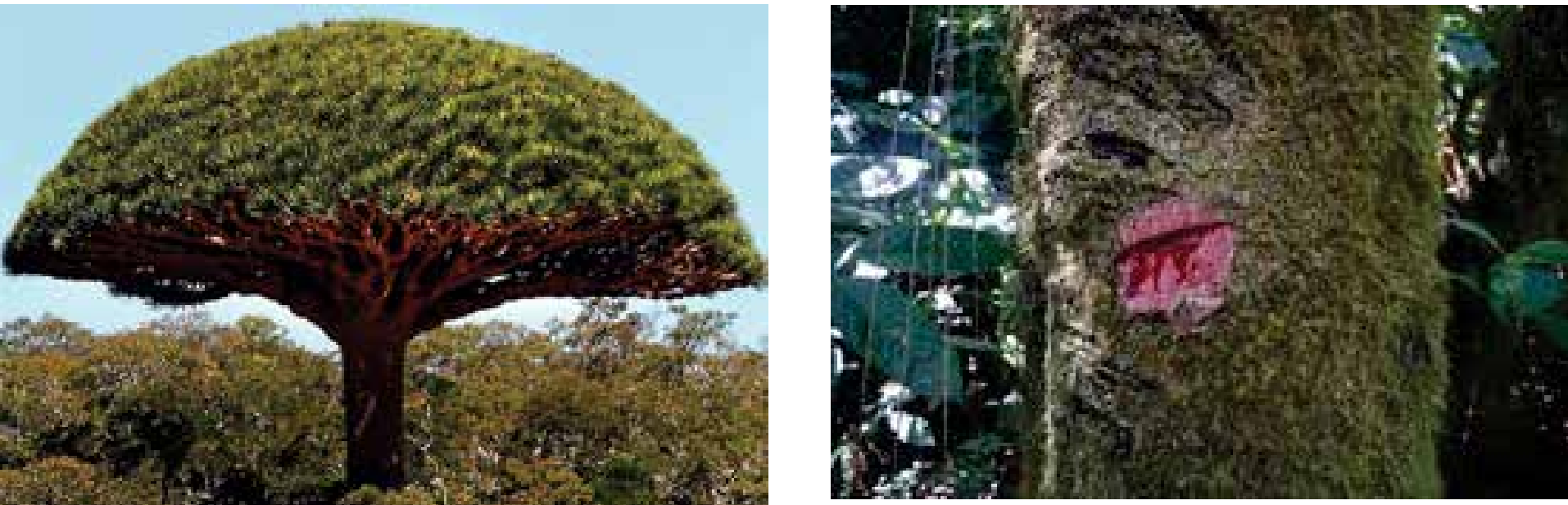

Figura 3. Árbol Croton spp. Productor de la sangre de drago.

Fuente: Internet. 2007

También sirven para extraer medicinas como la Sangre de Drago (Figura 3) poderoso cicatrizante, extraído del tallo de varias especies amazónicas como el Croton spp. o la Quina, alcaloide natural, que sirve para combatir el paludismo o malaria. Las partes que se usan con fines curativas son la corteza, ramas, tronco y raíz. La quina tiene propiedades medicinales como digestivo, antioxidante, antibiótico, astringente, anestésico, antiséptico y febrífugo. Este árbol es muy útil para tratar afecciones como diarrea, dolores menstruales, dolor de estómago, neuralgias y jaquecas, dolor de dientes, anemia, gota, gripe, raquitismo, falta de apetito, problemas capilares como caída del pelo, seborrea y caspa. Pero además la quinina es de gran ayuda para mejorar la salud de personas que sufren de enfermedades como el paludismo, malaria y fiebre amarilla, curar heridas y úlceras y fortalecer el sistema inmunológico.

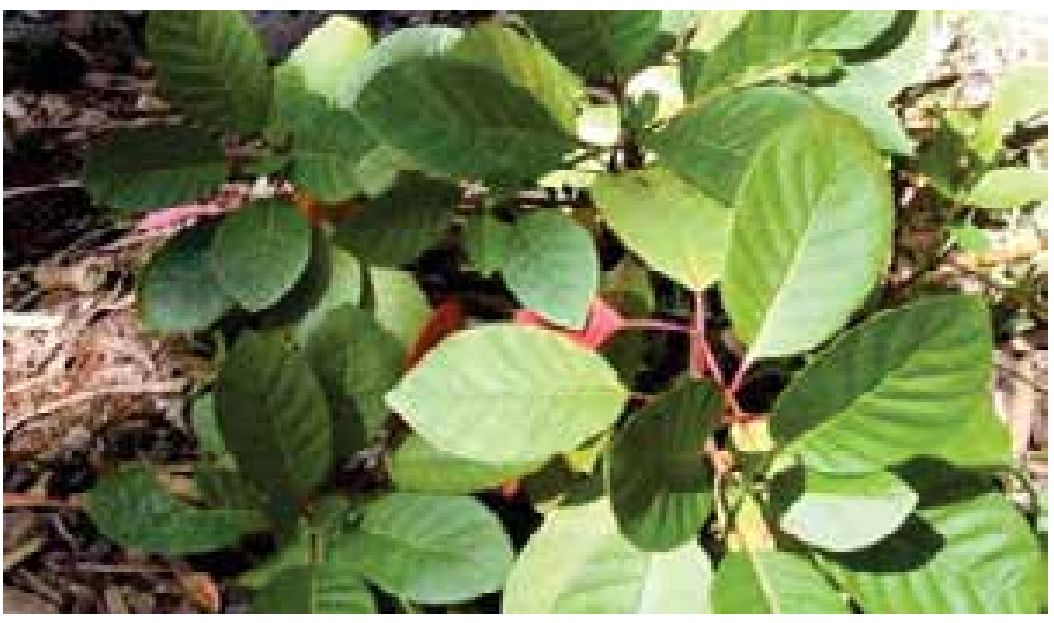

Figura 4. Árbol de Quina (Chinchona officinalis).

Fuente: Chalela, G. Foto Archivo personal. 2003 
Muchas de las sustancias producidas por las plantas han sido elaboradas por la propia evolución de las especies para adaptarse al medio y tener más posibilidades favorables de existencia. Así, algunas de estas moléculas sintetizadas por las plantas pueden reforzar la fortaleza de la planta frente a situaciones de estrés o repeler o suprimir a determinados patógenos que pretenden dañarla o comerla. Su eficacia depende de muchos factores, no todos ellos controlados totalmente; es por eso que los resultados pueden ser variables, en función del estado del cultivo, las condiciones de extracción, la calidad de la planta de la que se extrae la sustancia, entre otras. Un ejemplo lo constituye la planta de Borraja, Borrago officinalis su nombre científico, que es rica en ácido gamma linoléico utilizado contra la artritis.

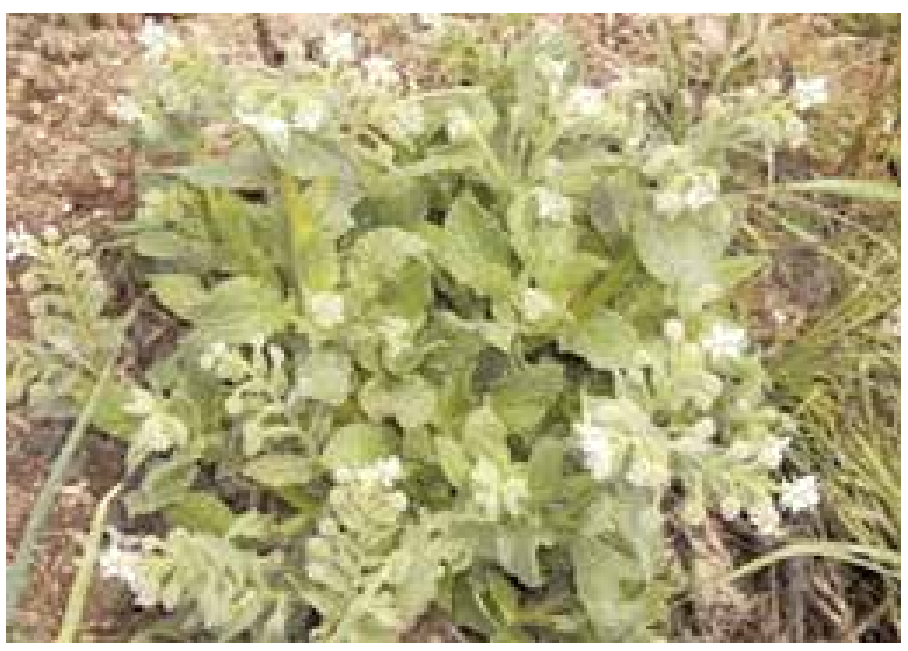

Figura 5. Planta de Borraja.

Fuente: Mogotocoro, A. Foto Berlin, Santander, 2016

Plantas ornamentales: Sirven para adornar parques, jardines e interiores de las viviendas. Como: Rosas, girasoles, orquídeas, guayacanes. Para el disfrute personal o para fines paisajísticos.

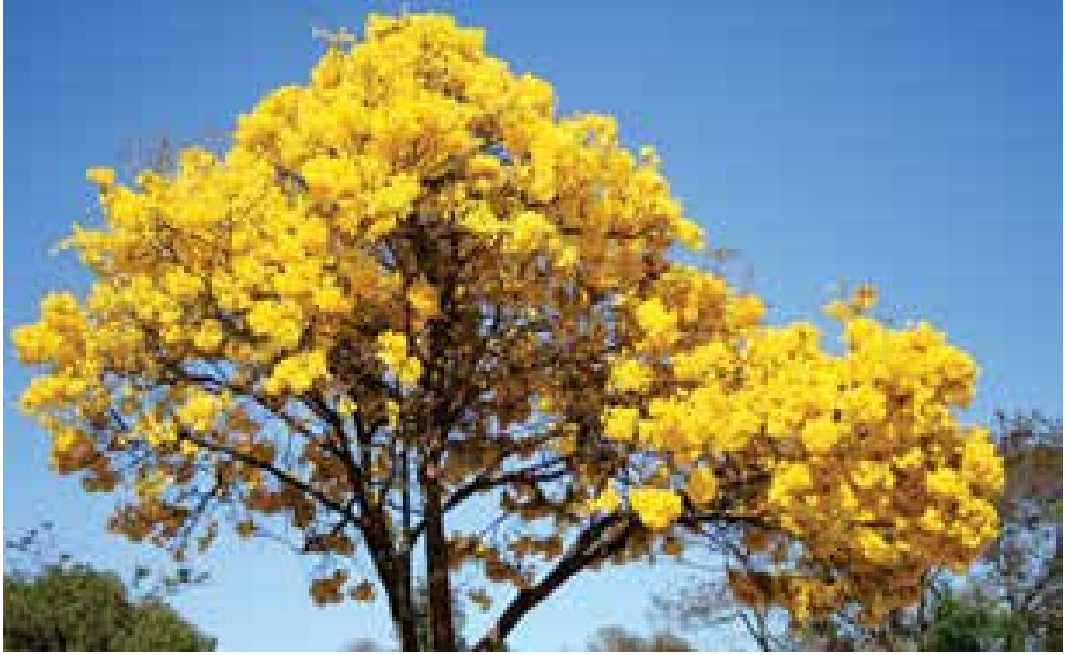

Figura 6. Guayacán amarillo, Tabebuia chrysantha. Fuente: Chalela, G. Archivo personal. 2003

Plantas industriales: De ellas se obtiene materia prima para la elaboración de telas como: Fibras de Algodón, Lino, Cabuya, Fique.

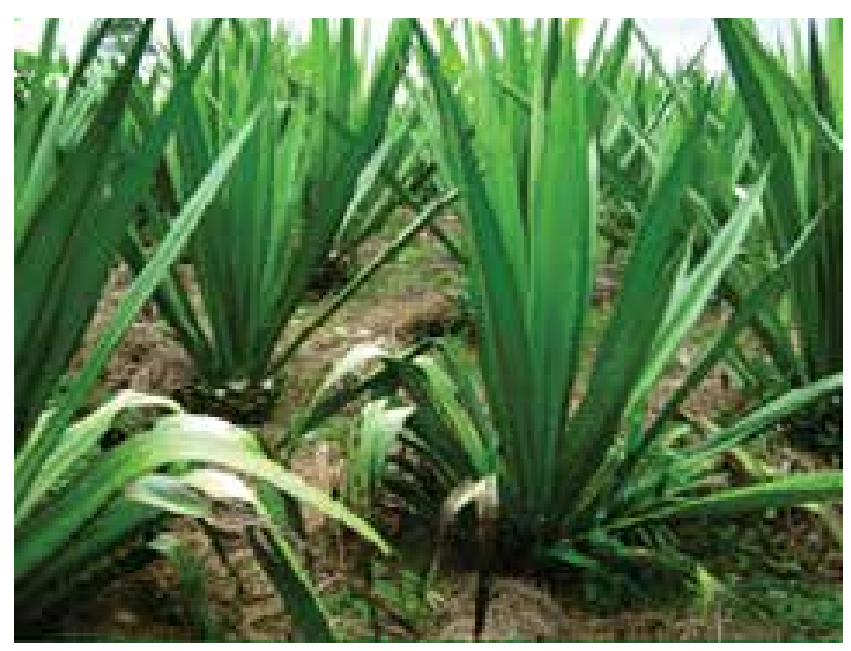

Figura 7. Planta de Fique, Furcraea bedinghausii, municipio de Curití Fuente: Chalela, G. Foto Archivo personal. 2014 
De otras plantas industriales se obtiene esencias para fabricar perfumes, algunas además son maderables como el Pino, Laurel, Caoba; del árbol del caucho, Hevea brasiliensis, se obtiene látex para fabricar artículos de caucho para diferentes usos.

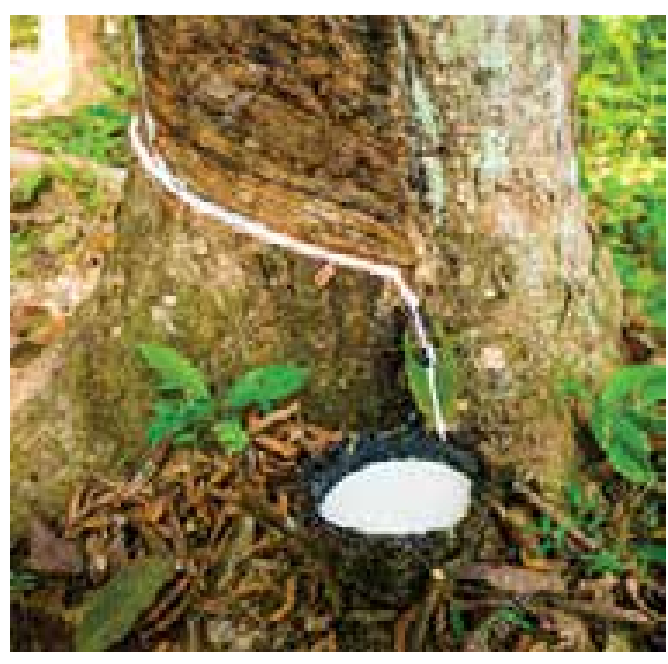

Figura 8. Extracción del latex de Hevea brasiliensis.

Fuente: Chalela, G. Foto Archivo personal. 2003

También existen las plantas anuales, las bianuales y las perennes, con las siguientes características:

Plantas anuales: son plantas herbáceas y de uso ornamental que completan su ciclo de vida en un único periodo de vegetación activa. En la fase de crecimiento, estas especies germinan, crecen, florecen, dan frutos, alcanzan su madurez y se secan. Este proceso se realiza en diez meses aproximadamente, según el clima. Se consideran plantas anuales también, a las plantas perennes de regiones más cálidas, que son incapaces de aguantar las bajas temperaturas del invierno. Estas plantas son cultivadas por lo vistoso de sus inflorescencias. Ejs. Caléndula, Alverja.

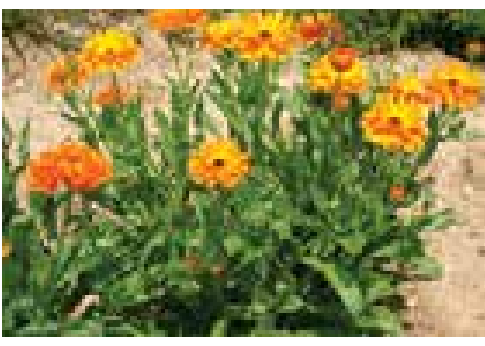

Calendula officinalis (Caléndula)

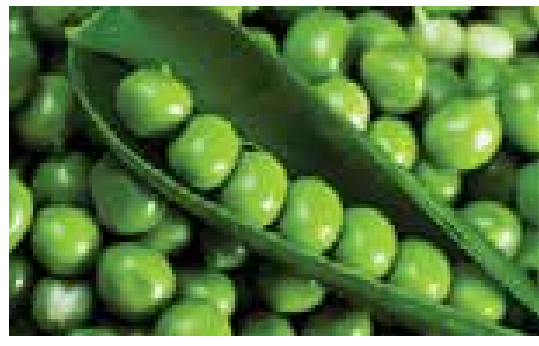

Pisum sativum (Alverja)
Plantas bianuales: La diferencia de este tipo de plantas con las anteriores, es que completan su ciclo vital en dos años. Como regla general, sus inflorescencias aparecen en la primavera del 20 año y después mueren. Su objeto de cultivo son también las flores. Ejs: Perejil, Cebolla, Zanahoria.

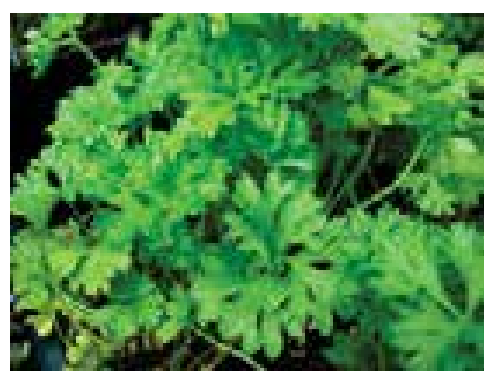

Petroselinum crispum (Perejil)

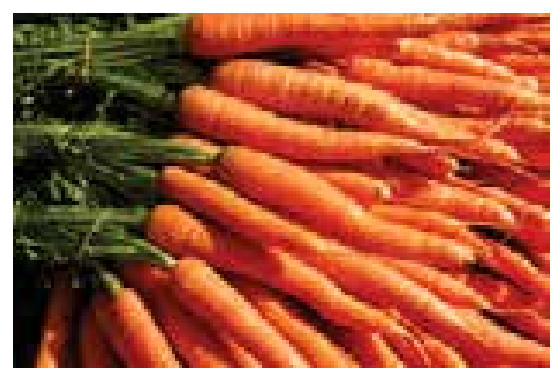

Daucus carota (Zanahoria)
Fuente: Chalela, G. Foto Archivo personal. 2009-2014

Plantas perennes o vivaces: A diferencia de las plantas anuales y bianuales, las perennes o vivaces florecen y dan semilla varias veces a lo largo de su vida. Estas plantas suelen perder la parte aérea en periodos de parada vegetativa (invierno), pero las raíces sobreviven. Al llegar la primavera vuelven a rebrotar y florecen, repitiéndose el ciclo vegetativo. Ejs. Tomillo, Fresa, Orégano, Kiwi, todos los cítricos. 


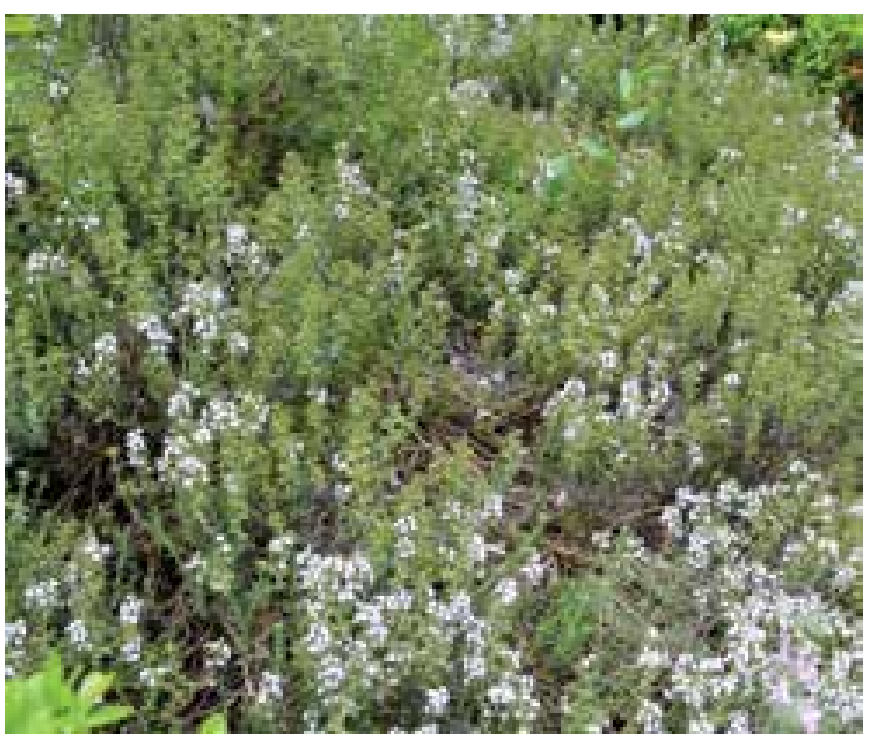

Thymus vulgaris (Tomillo)

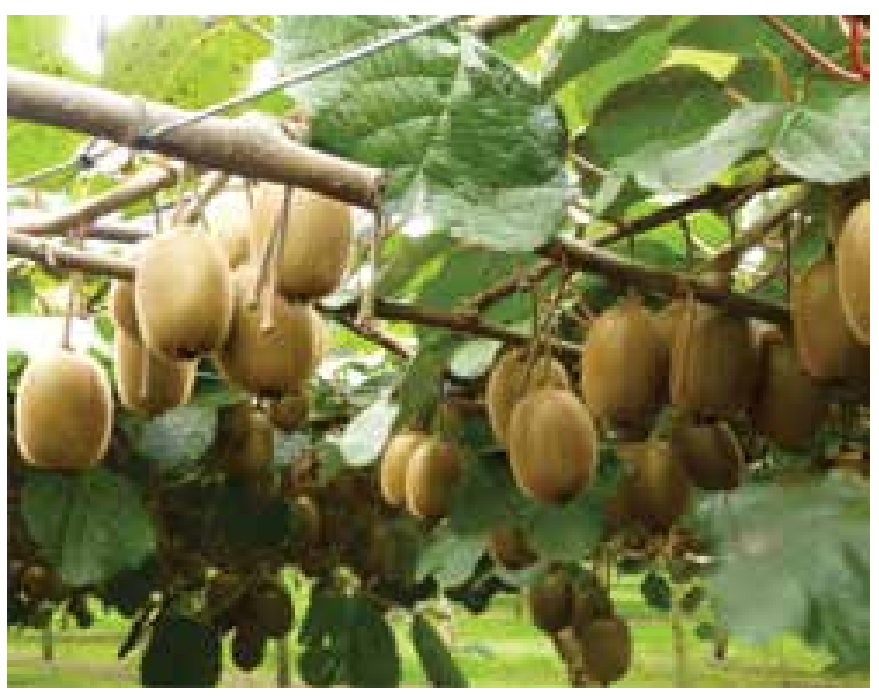

Actinidia deliciosa (Kiwi)

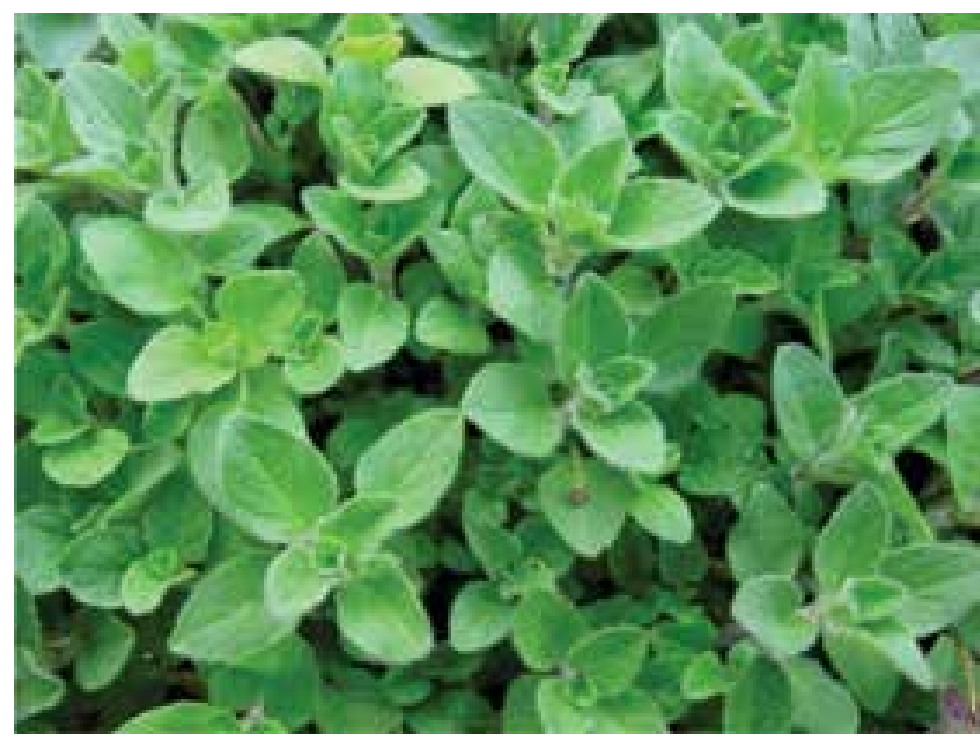

Origanum vulgare (Orégano)

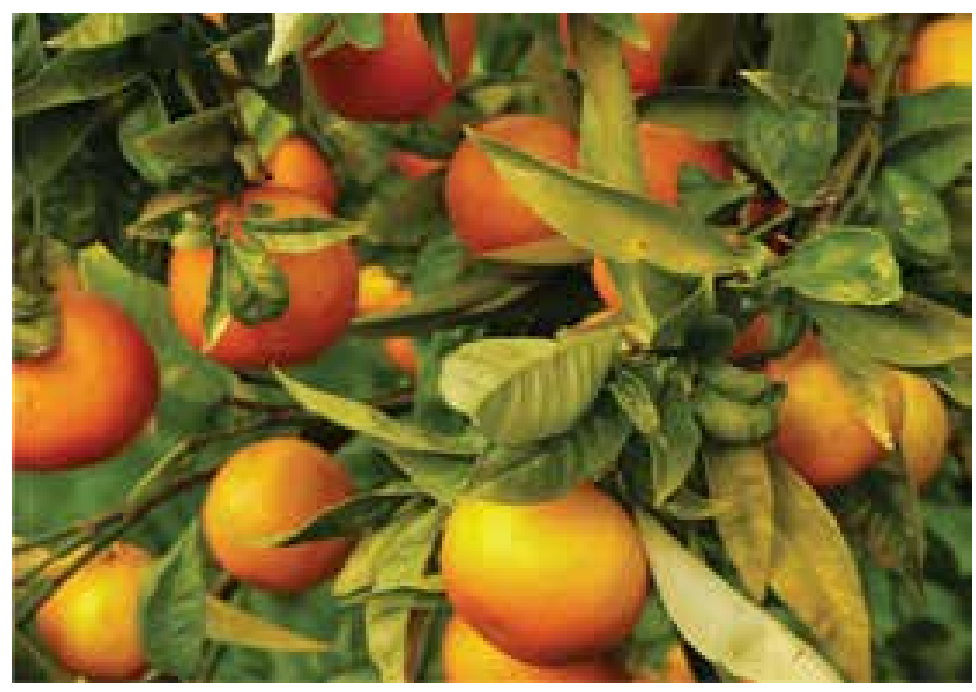

Citrus reticulata (Mandarina) 


\section{PLANTAS AROMÁTICAS}

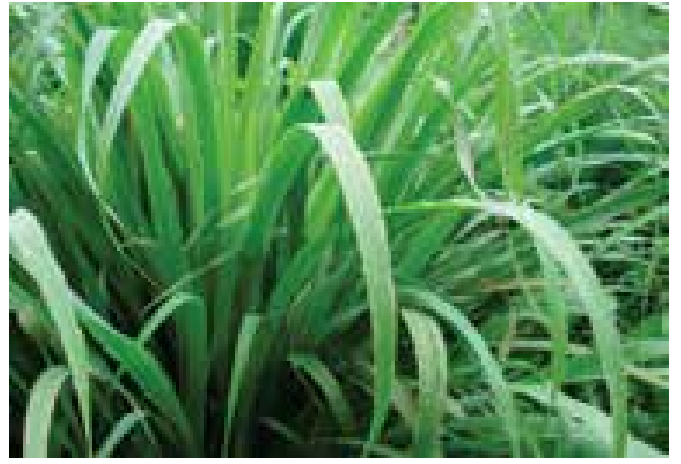

Limonaria

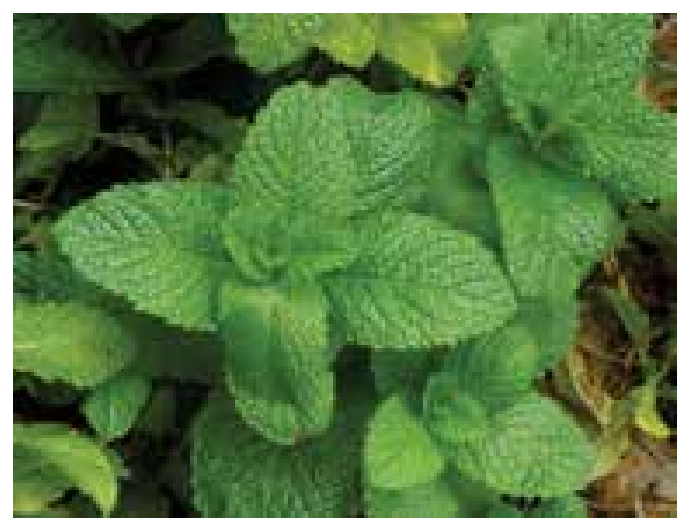

Yerbabuena

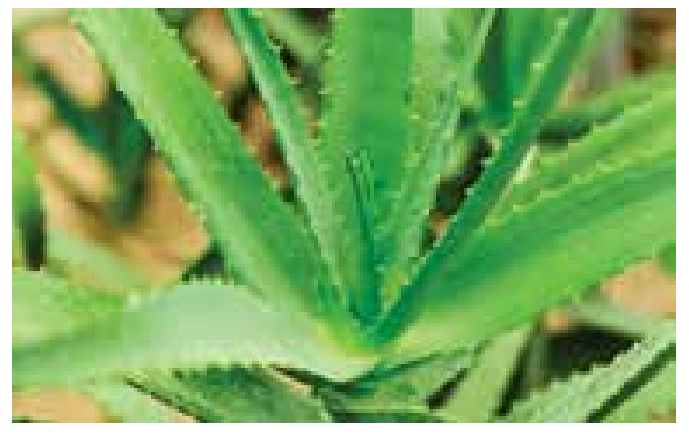

Sábila

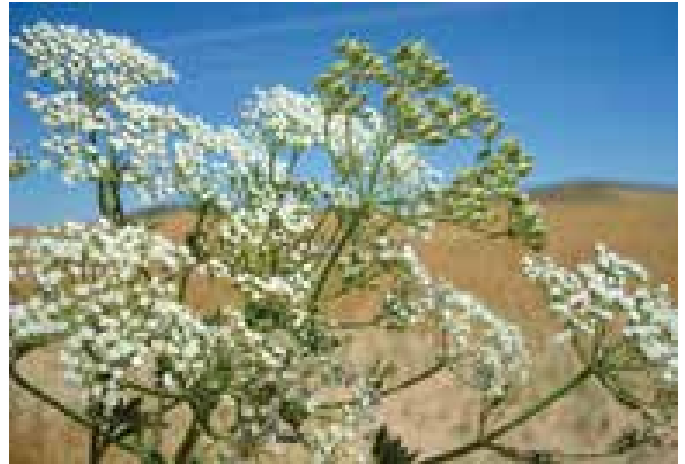

Anís

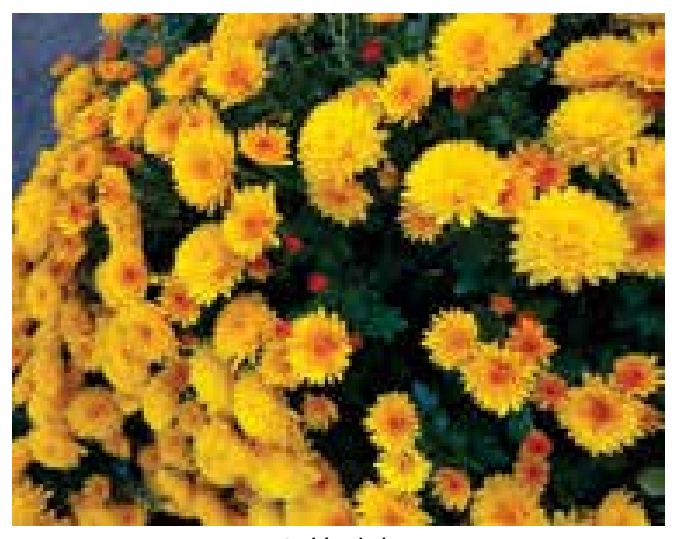

Caléndula

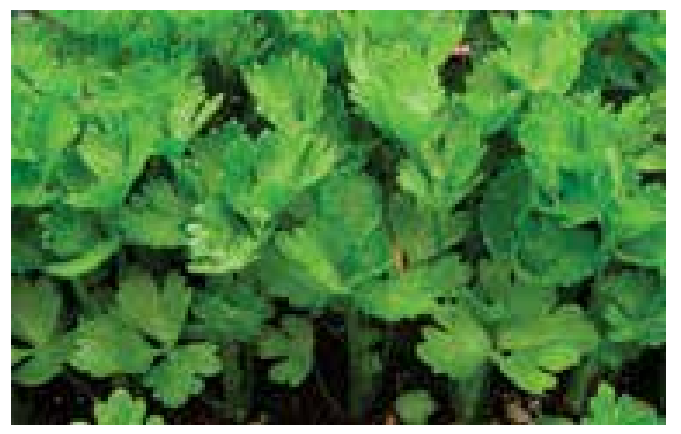

Apio

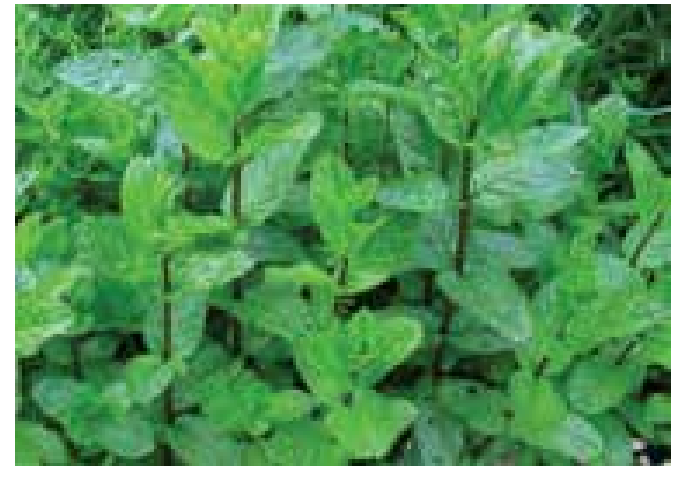

Menta

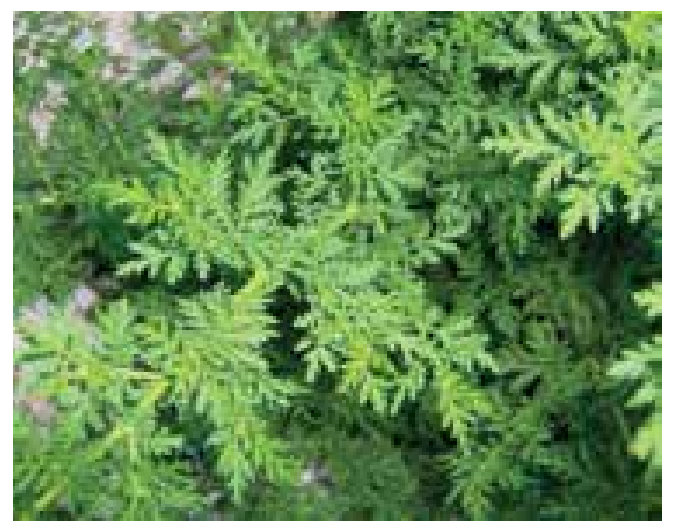

Citronela

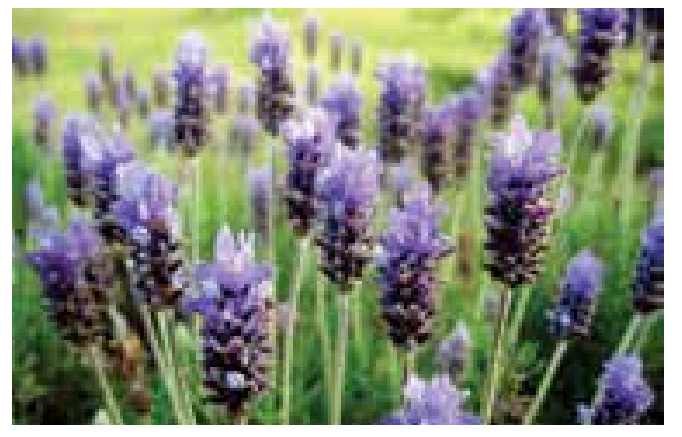

Lavanda 

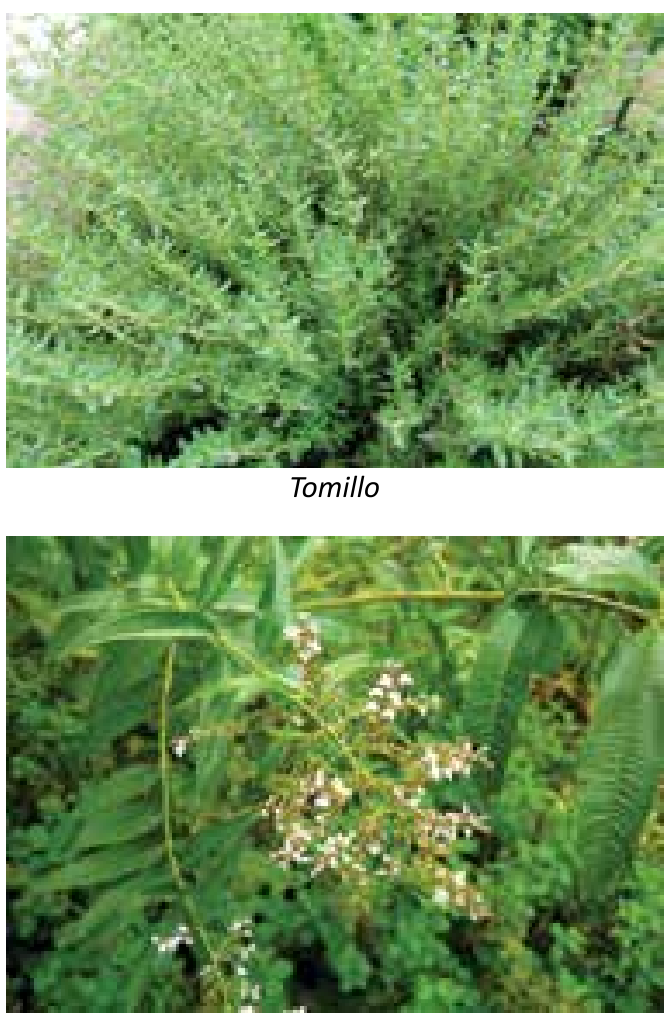

Cidrón

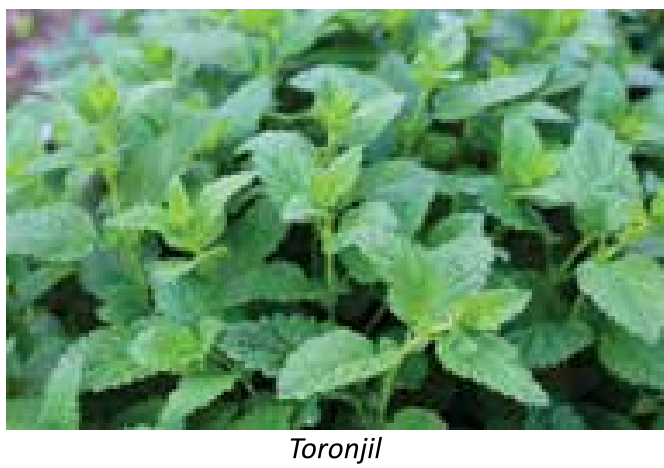

Figura 9. Algunas plantas aromáticas.

Fuente: Chalela, G. Foto Archivo personal. 2016

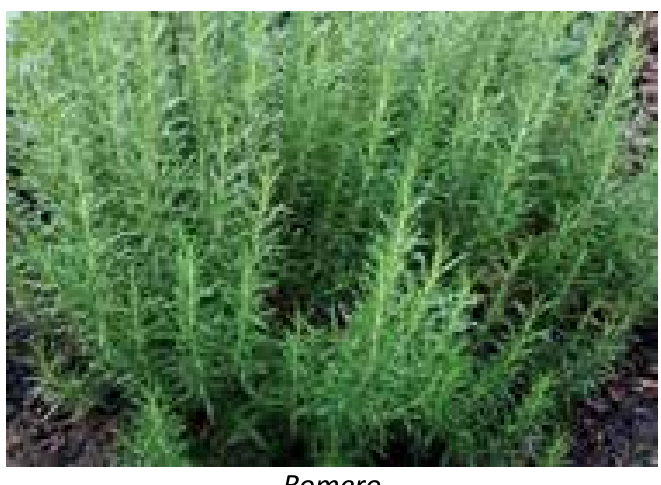

Romero

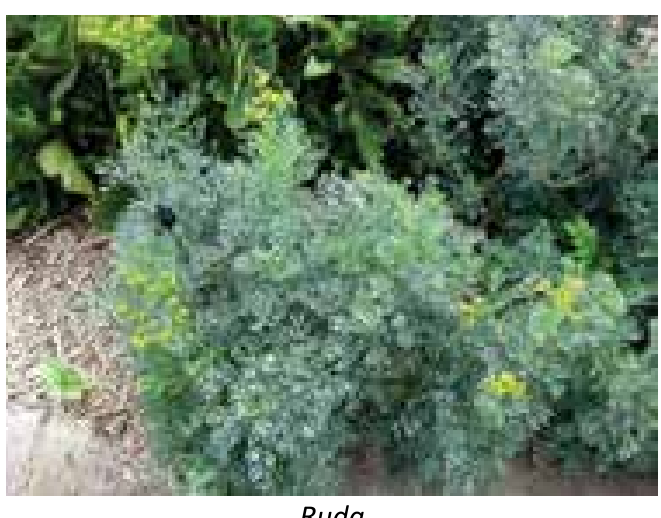

Ruda

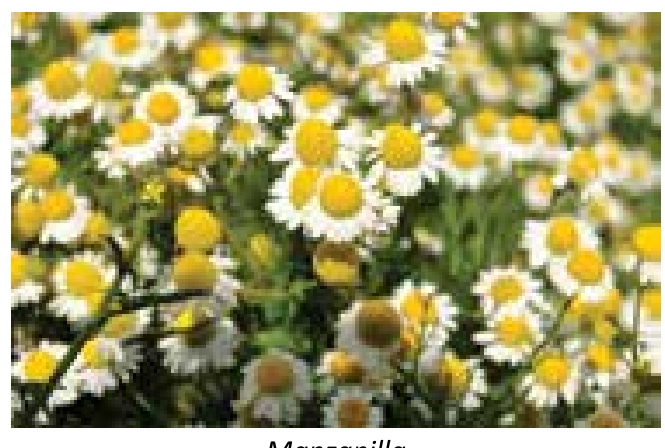

Manzanilla

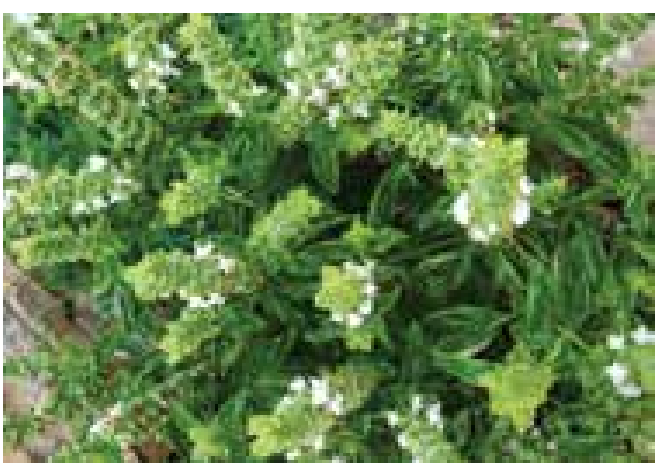

Albahaca

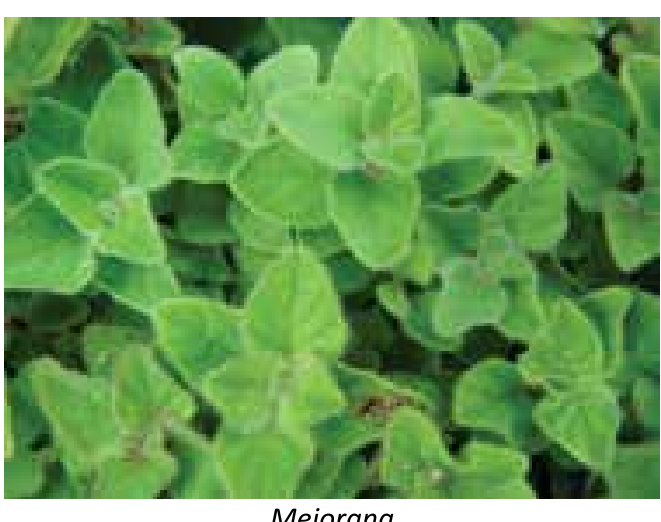

Mejorana

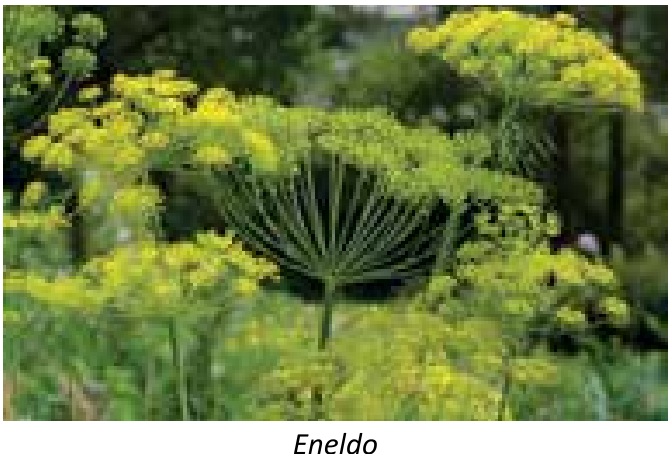

Eneldo 
Se denominan plantas aromáticas a todas las especies vegetales cuya importancia radica en poseer un aroma y/o sabor que la hace útil, esta propiedad está dada por componentes o fracciones volátiles que químicamente se denominan esencias o aceites esenciales. Los principios activos especificados anteriormente se pueden encontrar en: hojas, tallos, bulbos, rizomas, raíces, flores, semillas y frutos.

El uso de plantas medicinales se remonta a la época prehistórica en la mayoría de las culturas conocidas. A pesar del paso del tiempo y el avance de la tecnología médica, las plantas medicinales continúan siendo la panacea "de cabecera" de muchas familias. Esto es posible dado que algunas plantas liberan compuestos llamados metabolitos primarios, y metabolitos secundarios. Ambos compuestos concentran extractos que optimizan el funcionamiento de varias partes del cuerpo.

El cultivo de plantas aromáticas y medicinales ofrece muchas ventajas además de los beneficios para la salud, debido a las características de estas plantas. Agua, luz y una buena selección de especies vegetales con propiedades benéficas para distintas dolencias, pueden hacer de su huerta una verdadera "farmacia verde".

- Son una fuente viva de aromas y sabores y una farmacia natural.

- La mayoría son de talla pequeña y requieren poco espacio para su cultivo.

- Un gran número de ellas son perennes, bienales o se cultivan como plantas perennes.

- No se necesitan grandes recursos, especialmente si se cultivan de manera orgánica.

- Son ornamentales, ofrecen fragancias, colores, formas diferentes que alegran la huerta y tienen usos múltiples.

- Son plantas acompañantes de otros cultivos y algunas ejercen el control biológico de plagas y repelen insectos.
Es importante conocer bien las plantas para no entrar en confusiones ya que algunas son muy parecidas y tienen nombre diferente según el país. La menta se parece mucho a la hierbabuena y su principal diferencia radica en que la menta posee un tallo de color rojizo y la hierbabuena verde. Por sus propiedades estomacales se utiliza para favorecer los procesos digestivos, para combatir el mal aliento, contra la gingivitis, las náuseas y los espasmos intestinales, entre otros muchos usos.

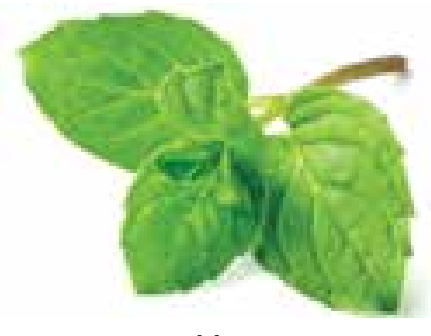

Menta

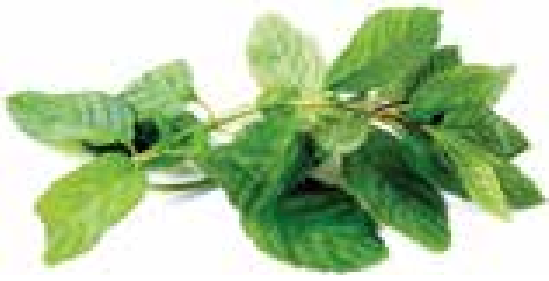

Yerbabuena
Fuente: Chalela, G. Foto Archivo personal. 2009

\section{PLANTAS CULINARIAS O CONDIMENTARIAS}

Son aquellas que se usan en la cocina, para condimentar guisos, sopas, ensaladas, postres, salsas, etc.

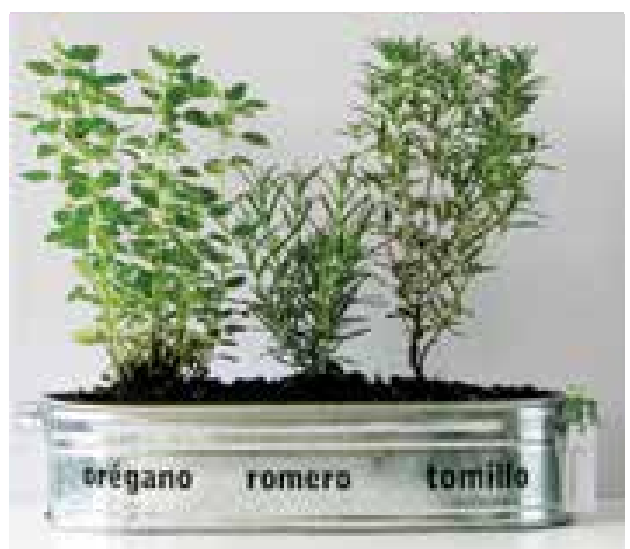

Las Hierbas más utilizadas para esto son, entre otras: Albahaca, Laurel, Menta, Orégano, Perejil, Romero, Salvia, Tomillo. La mayoría de plantas condimentarias son también plantas aromáticas y medicinales.

Figura 10. Algunas Plantas culinarias muy apreciadas para la sazón de alimentos.

Fuente: Internet, 2016 


\section{PLANTAS MEDICINALES}

Son aquellas que tienen propiedades curativas en alguna de sus partes (hojas, flores, semillas, raíces, etc.) y sirven para calmar, combatir o incluso, curar enfermedades. Hay miles de especies que se pueden considerar medicinales, tanto árboles, arbustos como herbáceas. Hay quien dice, que todas las plantas tienen propiedades medicinales por alguna razón u otra. Se usan en forma de infusiones, cataplasmas, etc.

La fitomedicina, se puede definir brevemente como el uso de las plantas como medio terapéutico para tratamiento de enfermedades y mantenimiento de la salud.

Dentro de esta rápida definición se destacan dos características fundamentales que demuestran la importancia del uso de las plantas.

La primera es utilizar el término planta, ya que las mismas no actúan como meros principios activos tal cual hacen las sustancias de síntesis, sino que toda la planta en su conjunto con sus distintas partes; componentes macro, microscópicos y ortomoleculares hacen a la acción terapéutica, lo que da una ventaja inestimable en amplitud de recursos a utilizar.

La segunda característica se refiere al hablar de salud y su mantenimiento en primera instancia, ya que las plantas son utilizadas como alimento habitualmente, lo que da la posibilidad invaluable de su uso de una forma sencilla que permite su acción a lo largo del tiempo y al alcance de todos.

Desde épocas remotas el hombre tuvo que aprender a vestirse, comer y curarse. Para ello debió mimetizarse con su entorno y aprender del comportamiento de los animales, que basados en su instinto sabían seleccionar las especies que eran consideradas comestibles, de aquellas consideradas como medicinales y también tóxicas.

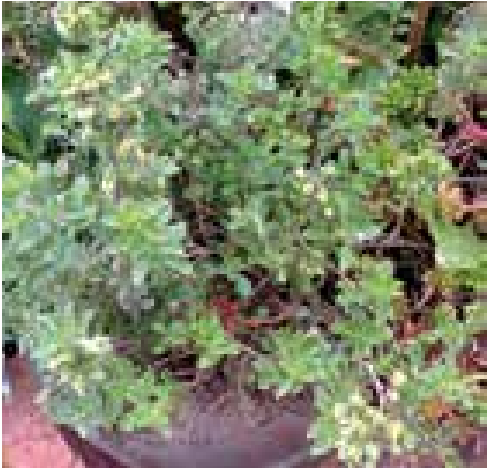

Origanum majorana (Mejorana) Planta de uso culinario y medicinal

Fuente: Mogotocoro, A. Foto Berlín, Santander

Este aprendizaje le demandó largo tiempo y no todos estaban preparados de igual manera para llevarlo a la práctica. Los continuos éxodos de muchos pueblos debidos a las constantes guerras conspiraron contra la adaptación del hombre a su medio o hábitat.

Sin embargo, en las primitivas aldeas hubo quienes desarrollaron un conocimiento más profundo y una adaptación al medio de forma muy superior al resto: ello motivó la aparición de los primeros chamanes quienes no solo tenían a su cargo el manejo de los problemas de salud de sus congéneres, sino que podían pronosticar cuáles eran las mejores épocas para el cultivo de sus semillas y la época de recolección.

Dentro de las llamadas civilizaciones avanzadas, los Egipcios dieron muestras de un profundo conocimiento médico, y a través del papiro de Ebers (primer documento médico de la antigüedad descubierto en 1872) demostraron las virtudes de muchas plantas medicinales en salud humana.

En Egipto, quienes profesaban el arte de curar era la casta sacerdotal perteneciente a los Brahamanes, ya que dentro de su concepción de vida "quienes tenían las facultades de reparar los problemas del espíritu, también podían reparar los trastornos del cuerpo...". 


\section{HORTALIZAS}

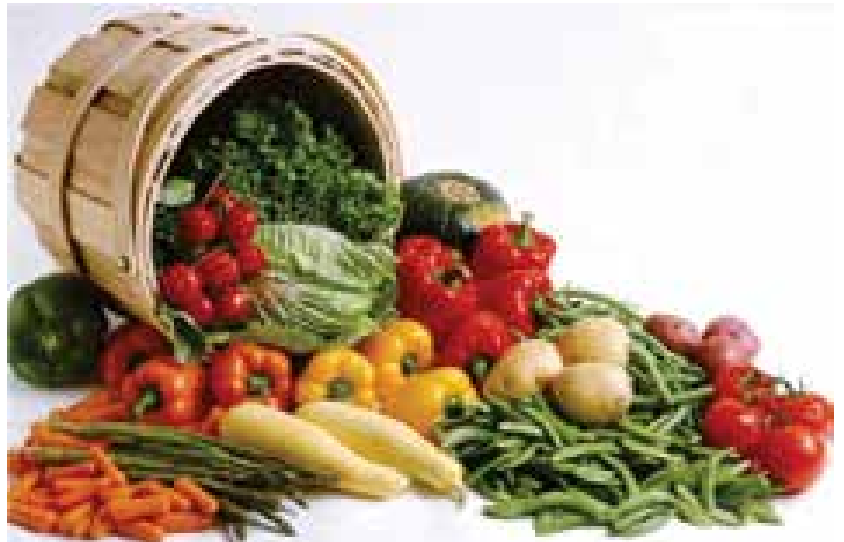

Figura 11. Hortalizas en general.

Fuente: Internet, mercado español.

Las hortalizas son un conjunto de plantas cultivadas generalmente en huertas o regadíos, que se consumen como alimento.

Las hortalizas son aquellas verduras y demás plantaciones comestibles que se cultivan generalmente en huertas y que mayormente se las consume como alimentos, ya sea de forma cruda o cocida.

Dentro del conjunto de las hortalizas, que por supuesto es amplio, se incluyen las legumbres verdes, tales como habas, los guisantes y las verduras.

Vale la pena destacar que las hortalizas de hoja verde son las verduras y aportan pocas calorías y tienen un gran valor alimenticio por su riqueza en vitaminas $A, C$, complejo $B, E$ y $K$, minerales como el calcio, el hierro y además fibra. El color verde se debe a la presencia de la clorofila. Son ejemplo de verduras: lechuga, escarola, repollo, achicoria, berro, acelga y espinaca.

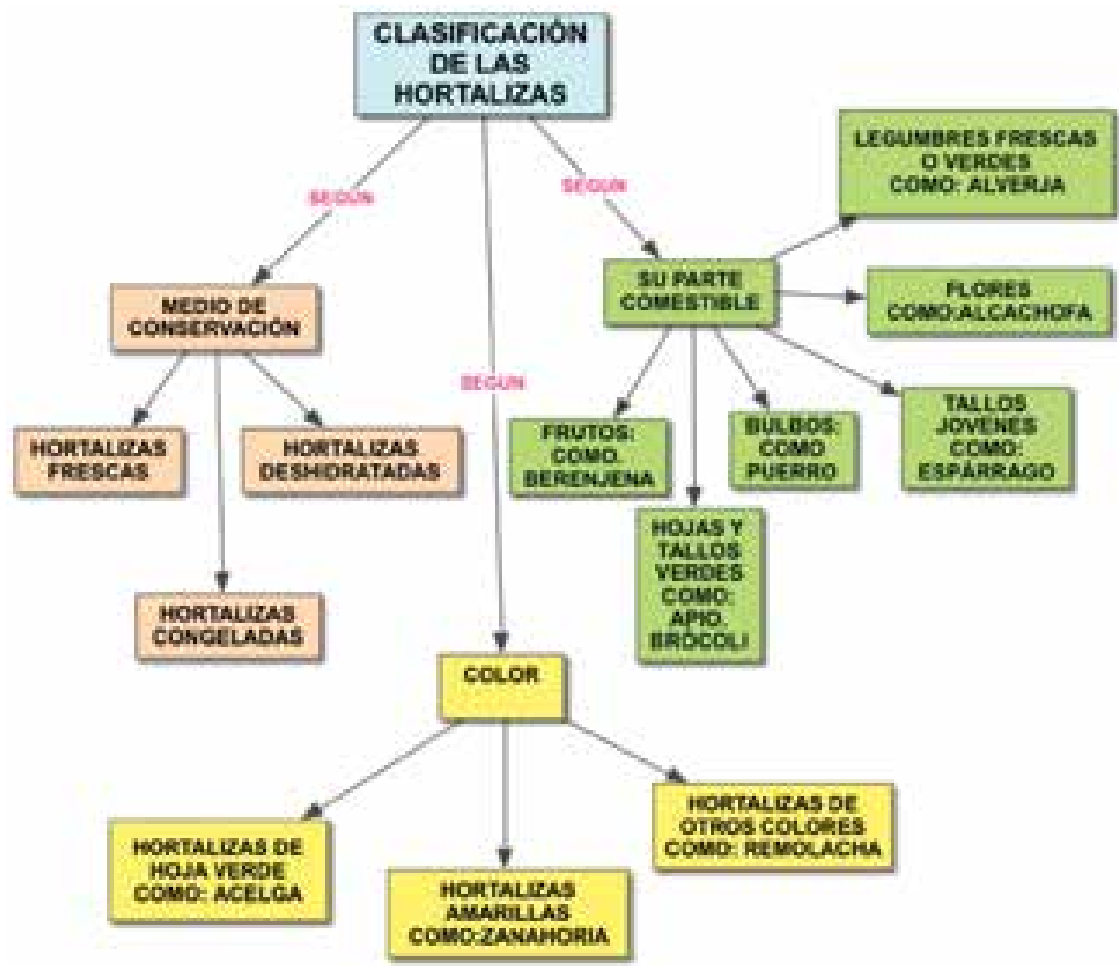

Figura 12. Clasificación de las hortalizas

Fuente: Chalela, G. Diseño diagrama importancia de las hortalizas. 2016

En cuanto a las amarillas son hortalizas ricas en caroteno, sustancia que favorece la formación de vitamina A. El caroteno se aisló por primera vez a partir de la zanahoria.

Existen hortalizas de otros colores que contienen poco caroteno pero son ricas en vitamina $\mathrm{C}$ y vitaminas del complejo $\mathrm{B}$ como la remolacha. 


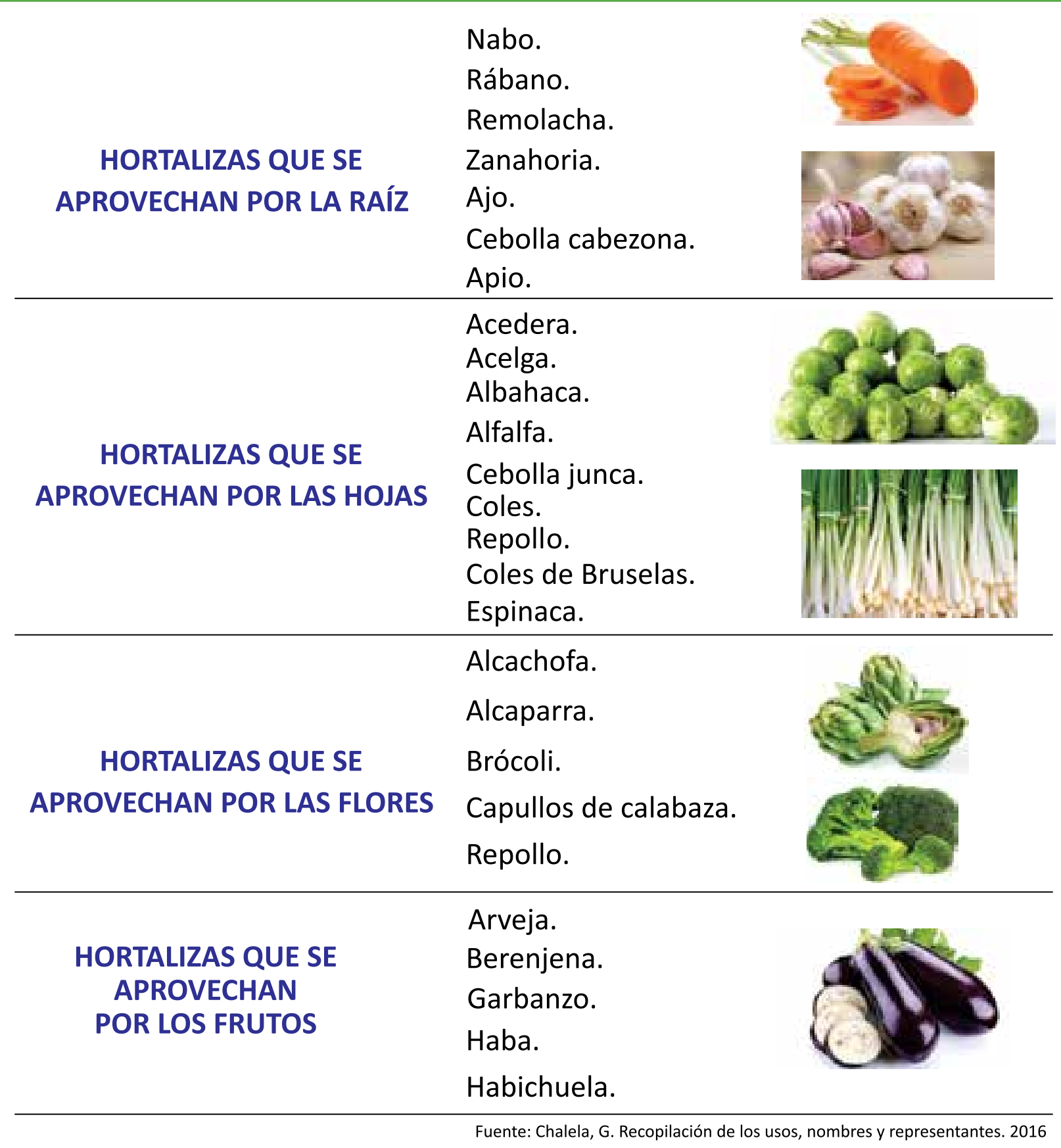


Vale la pena destacar el término leguminosas como un orden de plantas cuyo fruto es una vaina, como el frijol, el garbanzo, las habas y las lentejas. A medida que la planta madura, las vainas se secan y nacen las semillas; éstas últimas al madurar, almacenan alimento para que germine otra planta, por lo que tienen más nutrientes que cuando aún están frescas y verdes.

La Asamblea General de la ONU en Nueva York el 21 de Diciembre 2015, declaró el 2016 como el Año Internacional de las Leguminosas, proporcionando un excelente apoyo a la promoción de estos granos considerados por los expertos como los más saludables del mundo.

En los últimos 2 años, CICILS (Confederación Internacional de Comercio e Industria de Leguminosas Secas) se ha esforzado por garantizar que las leguminosas reciban la atención y el reconocimiento que se merecen. Los frijoles, las lentejas, las arvejas y los garbanzos han sido la piedra angular de la nutrición mundial desde hace siglos y a partir de la proclamación oficial de la ONU declarando el 2016 como Año Internacional de las Leguminosas, "se elevará la conciencia acerca del importante papel que pueden desempeñar estos alimentos en la promoción de la salud y la nutrición, así como la seguridad alimentaria y la sostenibilidad ambiental", comentó Hakan Bahçeci.

\section{VERDURAS}

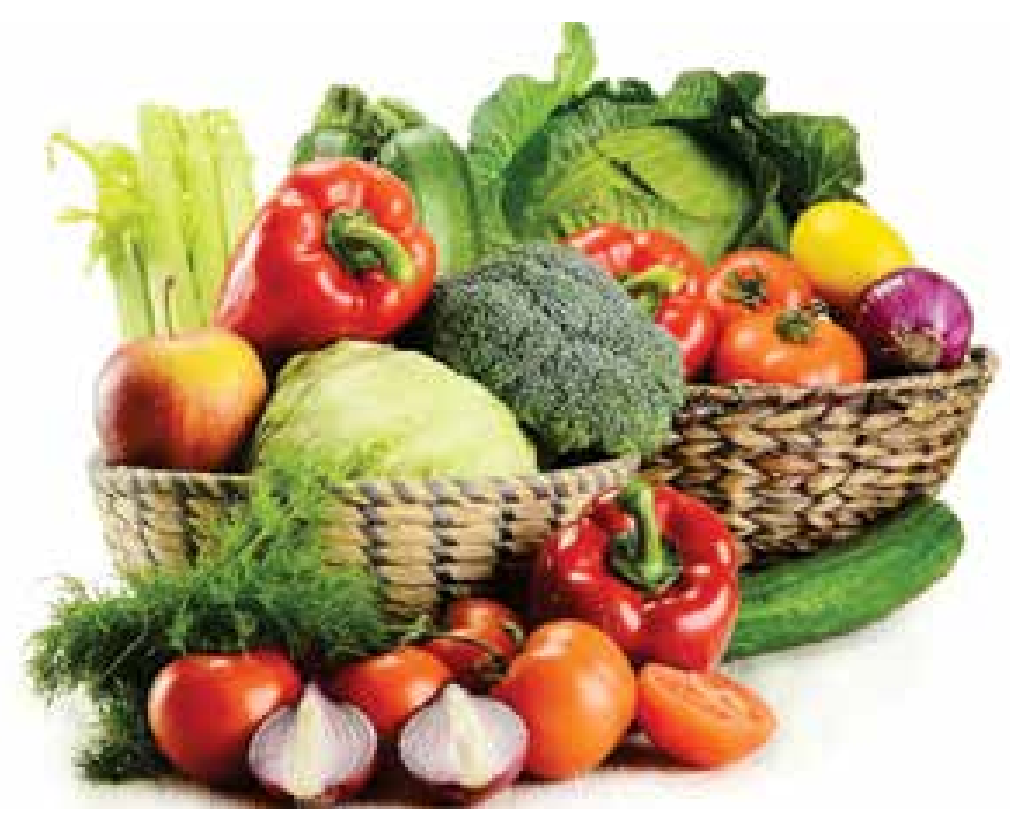

Figura 13. Las verduras

Fuente: Supermercado Carulla, Bogotá, 2003

El término verdura pertenece más al mundo de la alimentación que al de la botánica. Esta palabra tiene un significado muy amplio, pues abarca diferentes órganos de plantas muy diversas.

Desde la cocina o desde la horticultura, se entiende como verdura a cualquier parte verde de las hortalizas. Las verduras forman parte de hortalizas, entendiendo por hortaliza, cualquier producto que se produzca en la huerta y que no sea fruta. 


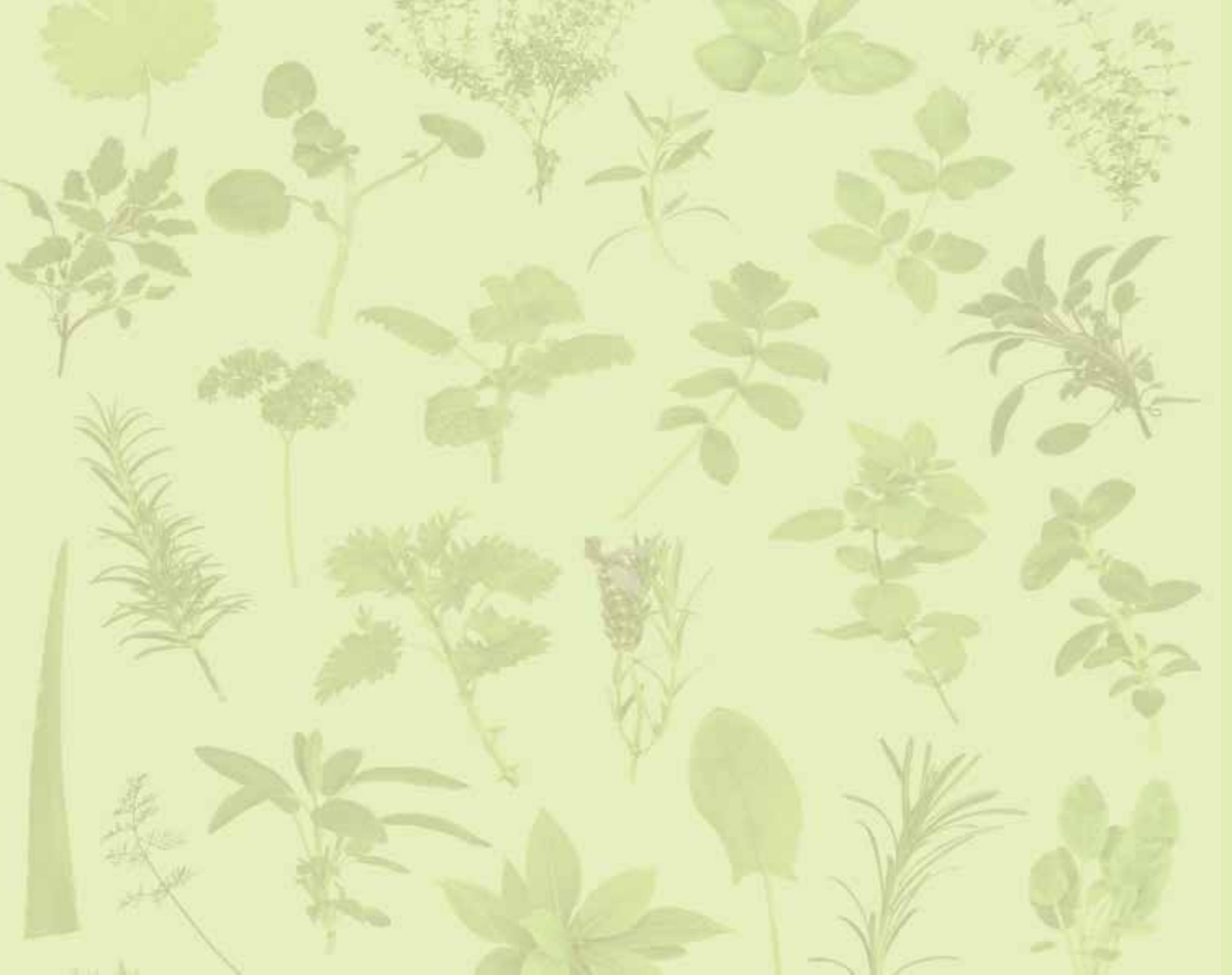




\section{CAPÍTULO 2.}

\section{PREPARACIÓN DEL SUELO PARA LA SIEMBRA}

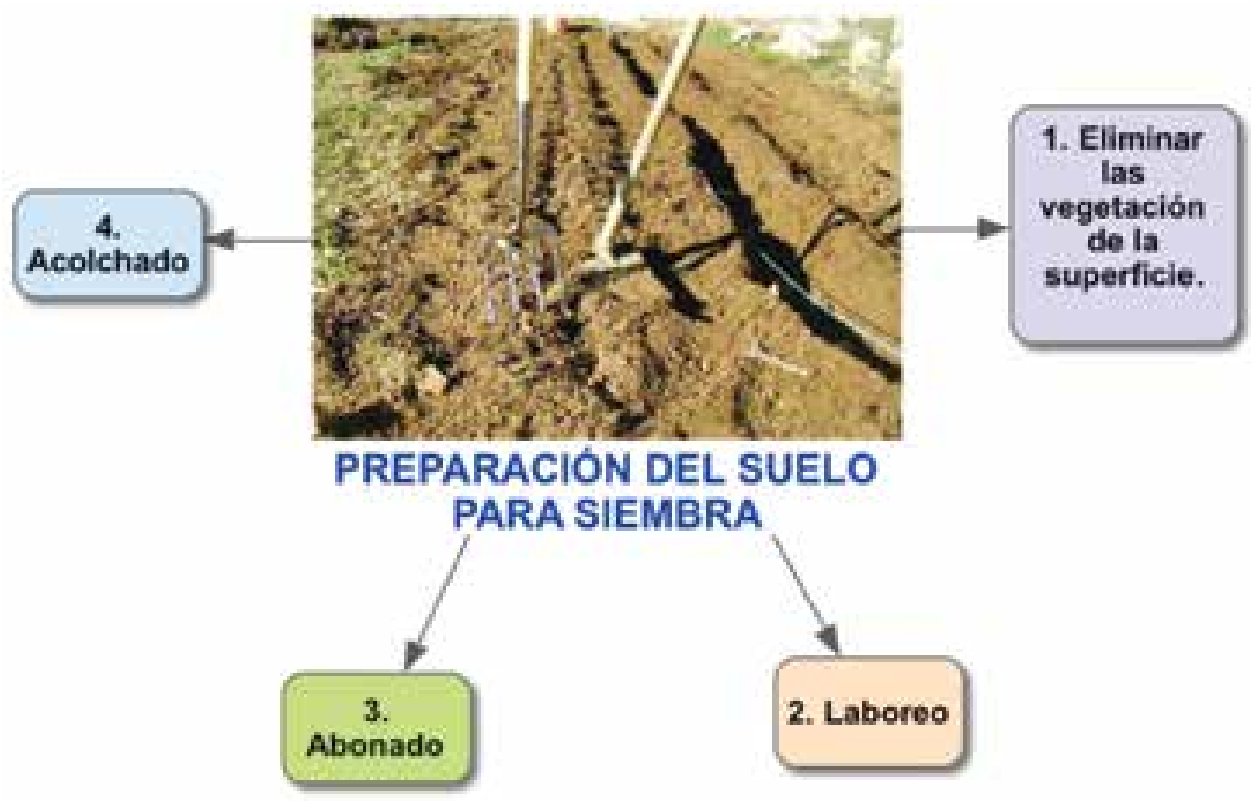

Figura 14. Preparación del suelo para la siembra.

Fuente: Chalela, G. Diagrama propio. 2016

Preparar la tierra para la siembra es una tarea importante para obtener buenas cosechas, ya sea en un huerto o en la casa o en la agricultura tradicional. El suelo debe ser muy bien preparado, de manera que las raíces de las plantas puedan ser sembradas o reasentadas de forma rápida y sencilla. Igualmente es necesario eliminar todas los componentes nocivos y lo insectos que puedan perjudicar al huerto.

Al preparar la tierra para la siembra, de forma mecánica o manual, podemos aprovechar para añadir nutrientes, como materia orgánica o compostaje, con el fin de mejorar las características del suelo. Recordemos que hay varias clases de suelo. Algunos son ricos en arcilla, otros en arena, y otros muy ricos en nutrientes.

La preparación del terreno es un conjunto de actividades que tiene como objetivo preparar una buena cama de siembra, que asegure la germinación y emergencia de la semilla. Sin embargo, ello no depende sólo de la forma en que se realice la preparación de la cama, sino de las características físicas y genéticas de la semilla, así como de la manera en que se deposite en la cama de siembra.

La siembra es una actividad agrícola que consiste en colocar la semilla en el suelo. O sea al hecho de poner o esparcir semillas en la tierra o en recipientes preparados para ello, con el fin de que germinen y emerjan nuevas plantas. Los cultivos se pueden sembrar durante los doce meses del año en los diversos tipos de clima y suelos, acompañada de otros recursos como agua disponible, fertilizante, prácticas culturales.

Para tener una buena siembra es importante tomar en cuenta el tamaño de la semilla y así saber la profundidad de la siembra, las necesidades de espacio, 
agua y aire de la planta, para establecer correctamente la distancia entre las plantas.

Los pasos son los siguientes:

1. Eliminar la vegetación de la superficie.

2. Laboreo: con la azada, se remueve el suelo, el trabajo dependerá de la compactación del suelo se debe trabajar hasta conseguir una profundidad de unos $50 \mathrm{cms}$ aproximadamente.

3. Abonado: añadir compost y/o tierra vegetal. Se recomienda 4 a 5 kilos de abono por metro (aproximadamente unos $5 \mathrm{~cm}$ de grosor encima del bancal) si la tierra tiene demasiada arcilla, es recomendable añadir arena para mejorar la porosidad y estructura del suelo.

4. Acolchado: es aconsejable para que el suelo quede esponjoso agregar una última capa con paja o restos de compost más duros, que sirvan además para retener la humedad y evitar costras y erosión en el cultivo.

Para que el huerto se mantenga sin problemas a lo largo del tiempo, se tiene que empezar creando unas buenas condiciones; esto significa crear un buen suelo.

Debe tenerse en cuenta que será el lugar donde germinará y crecerá toda la comunidad de hortalizas año tras año. Si no se da importancia a este aspecto se verá en el futuro, por muy bien que sea el primer y segundo años, la producción y aspecto del huerto empeorará con el tiempo, si no se hace lo necesario para crear y mantener un buen suelo.

Lo ideal es obtener un suelo mullido, que prácticamente el dedo índice se pueda hundir fácilmente en la tierra. $Y$ si falta materia orgánica, (tierra de color oscuro y olor a bosque) añadirla a través de estiércol y compost todos los años, para finalmente obtener un suelo esponjoso, con el suficiente alimento para las plantas.

\section{Herramientas}

Las herramientas que se necesitan para la preparación del terreno son las siguientes:

Azadas: para la preparación no es suficiente con una azada para laboreo. Existen multitud de tipos de azadas, con una función específica, de distinto tamaño o forma en función de la tarea: binadera (para romper la tierra), darra (para binar y escardar entre líneas de hortalizas), almacofre (para hacer surcos)

Rastrillo: para quitar terrones duros del suelo, malas hierbas y nivelar la parcela de tierra. Es decir, para dejar la parcela limpia y preparada para la siembra o trasplante.

Horca: utilizada para quitar algunas hierbas de raíz de la parcela de cultivo y mover el material en descomposición del compostador.

Criba: herramienta a modo de colador, que sirve para tamizar el compost y evitar material aún no compostado o demasiado grueso.

Carretilla: para transporte de tierra, herramientas. Además de semilleros, plántulas

Pala: para grandes movimientos de tierra: compost, abono, tierra vegetal. La pala cuadrada se utiliza también para el laboreo de la tierra. Consiste en pisar la herramienta para que entre en el suelo y posteriormente inclinar el mango de madera para levantar la tierra. Con ello se consigue realizar un buen laboreo y "agacharse menos" que con la azada. 
En la figura 15 se observan las herramientas utilizadas para el laboreo.

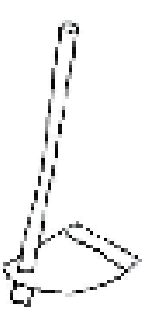

Arads

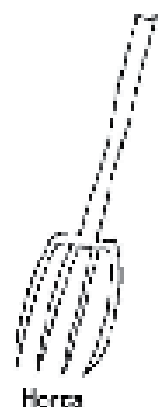

Heres

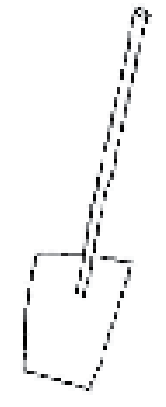

Fala cuastods

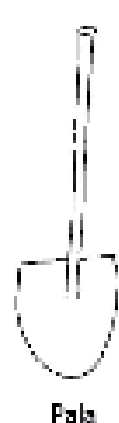

Pala
Figura 15. Herramientas Utilizadas en la Preparación del Suelo. Fuente. Internet

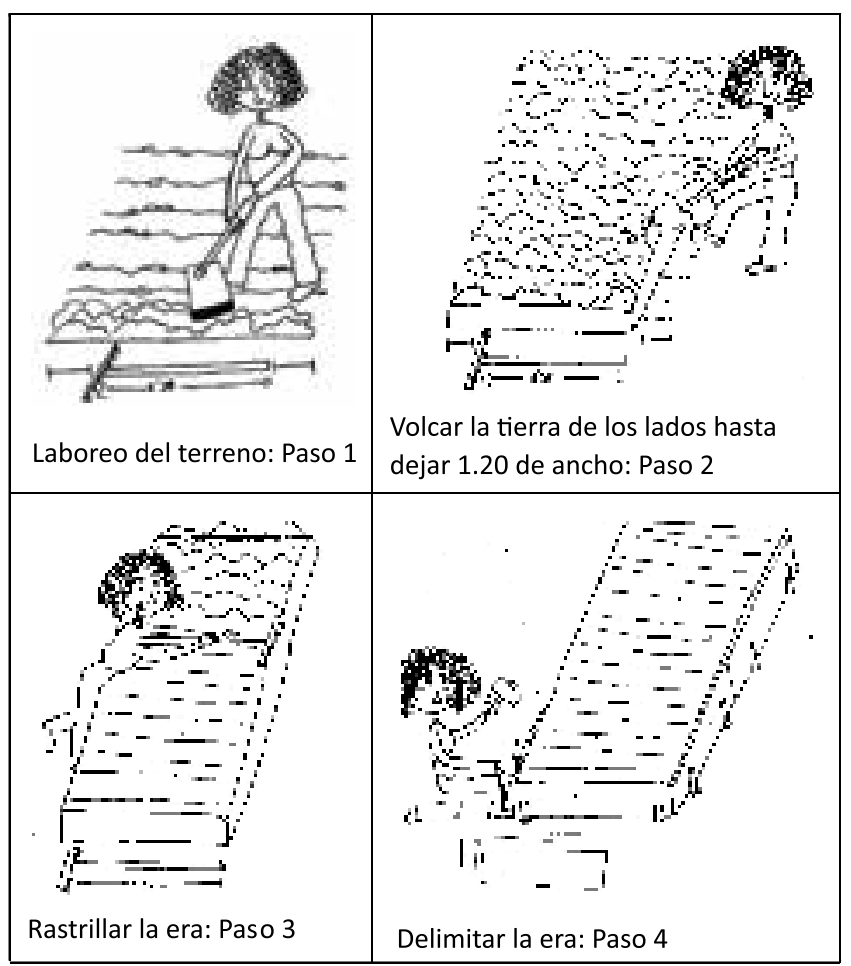

Figura 16. Ilustración de los pasos para la preparación del suelo y posterior siembra.

Fuente: Ecoagricultor
Además de una buena preparación del suelo, si observamos detalladamente los cultivos podemos hacernos una pequeña idea de las cantidades de macronutrientes o micronutrientes de nuestro suelo. Veamos algunas de estas pistas:

Macronutrientes: se suelen encontrar en grandes cantidades en el suelo y son los nutrientes principales para nuestras plantas.

\section{Nitrógeno}

Su ausencia se debe a falta de materia orgánica, aunque también es muy común en plantas cultivadas en maceta.

Consecuencia: brotes cortos y finos, porte delgado y erguido. En las primeras etapas de crecimiento las hojas son pequeñas y pálidas, luego pueden presentar manchas brillantes de amarillo, naranja, rojo o púrpura.

Remedio: aplicar compost o abono verde en la parcela.

\section{Fósforo}

Su disminución suele ocurrir en zonas lluviosas o épocas de mucha lluvia. Y en zonas arcillosas.

Consecuencia: los síntomas son parecidos a los del nitrógeno, pero es más frecuente que las hojas sean más verdiazules o más bronceadas con puntos púrpura en vez de amarillos o rojos. Los frutos se convierten en una pulpa blanda, ácida, de piel verde o rojiza

Remedio: aplicar harina de huesos (aproximadamente $150 \mathrm{~g} / \mathrm{m}^{2}$ )

\section{Potasio}

En suelos arcillosos cuando son hortalizas demandantes de este minerales como son las papas, tomates (las semillas tienen gran cantidad de potasio), judía y frutales. Pero es más común en tierras de arena y turba. 
Consecuencias: retraso del desarrollo de la planta y hojas pálidas de color verde azulado, con manchas marrones en ápices o alrededor del margen, $y$ a veces incluso se doblan hacia abajo.

Remedio: aplicar materia orgánica o cenizas de madera (rica en este mineral)

\section{Magnesio}

Su ausencia es muy frecuente en todas las plantas, se lixivia fácilmente y se inutiliza por exceso de potasio.

Consecuencia: aparecen en las hojas más viejas clorosis (amarillamiento) que se extiende posteriormente hacia arriba. También aparecen tintes brillantes de color pardo anaranjado y rojo y las hojas caen prematuramente.

Remedio: probar con agua con jabón o diluir gotas de detergente líquido suave.

\section{Calcio}

No suele afectar a hortalizas ni jardines, pero puede ocurrir si hay exceso turba en el suelo.

Consecuencia: en los tomate podredumbre apical y amargas las manzanas.

Además de los anteriores las plantas necesitan: Azufre, Carbono, Hidrógeno y Oxígeno.

Micronutrientes: La disponibilidad de los micronutrientes es esencial para el adecuado crecimiento y desarrollo de las plantas y para obtener rendimientos elevados. Cuando existe deficiencia de uno o varios elementos menores, éstos se convierten en factores limitantes del crecimiento y de la producción aunque existan cantidades adecuadas de los otros nutrientes.
En los últimos años se ha incrementado el uso de los micronutrientes en los programas de fertilización debido principalmentea:

- La continua remoción de elementos menores por los cultivos que en algunos casos, ha disminuido la concentración de éstos en el suelo a niveles abajo de lo necesario para el crecimiento normal.

- El cultivo intensivo, con un mayor uso de fertilizantes para aumentar rendimientos, que ha incrementado la utilización de elementos menores los cuales no son devueltos al suelo al remover la cosecha.

- La excesiva acidez de los suelos que reduce la disponibilidad de algunos micronutrientes.

- El uso de fertilizantes de alta pureza que han eliminado el aporte de los elementos menores que en pequeñas cantidades estaban presentes en productos de más baja calidad usadas en el pasado.

- Un mejor conocimiento de la nutrición vegetal que ha ayudado a diagnosticar deficiencias de elementos menores que antes no eran atendidas.

\section{Hierro:}

Más frecuente en zonas de suelos alcalinos, con pH mayor de 7,5.

Consecuencia: síntomas en brotes jóvenes principalmente y en casos extremos en ápices y márgenes de las hojas síntomas de abrasamiento. Pero es difícil diferenciar de síntomas como el magnesio y manganeso, aunque si el suelo es ácido se descartaría la opción de falta de hierro.

Remedio: mezclar la tierra con materiales ácidos como turba, helechos triturados.

\section{Manganeso:}

Suele aparecer en suelos de arena, turba, aluvión o arcilla, o cuando el $\mathrm{pH}$ es muy básico, y entonces aparece unido a deficiencia de hierro. $\mathrm{O}$ 
en época de mucha lluvia, ya que en suelo húmedo suele inutilizarse.

Consecuencia: similares a la ausencia de magnesio: clorosis en las hojas, aunque también se producen en guisantes y remolachas:

-Remolacha: enrollamiento del borde de las hojas que hacen una forma triangular y manchas amarillas entre los nervios. En casos extremos toda la hoja se vuelve amarilla.

-Guisante: cavidad o mancha de color rojo en el centro de los guisantes. Las vainas normales pero hojas algún amarillamiento entre los nervios.

\section{Boro}

El exceso de cal lo inactiva del ciclo de nutrientes.

Consecuencia: síntomas específicos en remolacha, nabos y perales.

\section{Molibdeno}

Se encuentra y se biodispone en suelos ácidos.

Consecuencia: solo en las coles y suele verse al crecer las hojas con poco limbo en comparación con el nervio central. Son hojas delgadas y arrugadas. Además no se desarrollan las cabezas.

Remedio: encalar antes de sembrar o plantar.

\section{Tipo de riego}

Una vez preparado el terreno, se debe pensar en tipo de riego que mejor se ajuste.

Para los surcos, lo ideal es instalar un riego por goteo. Es aconsejable montarlos después de la preparación del terreno, antes que la siembra o trasplante de cultivos, ya que se conocerán de antemano las manchas de humedad y se pueden distribuir de forma más eficaz las plantas.

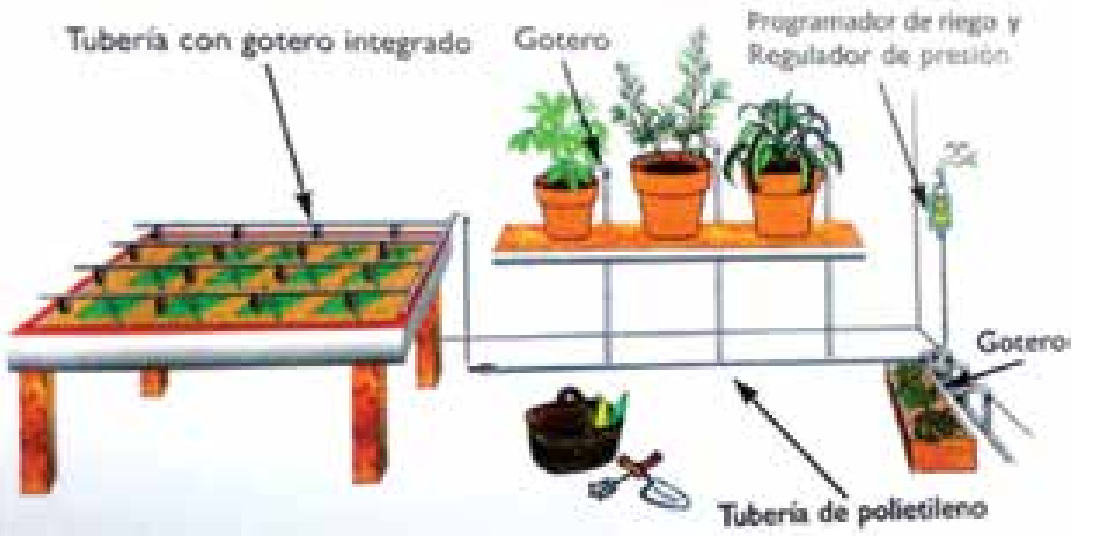

Figura 17. Sistema de riego por goteo. Fuente. Agrohuerto.2011

Por su comodidad y sus ventajas en cuanto al uso de agua, el más común de los sistemas de riego automático es el riego por goteo. Este sistema:

- Supone un importante ahorro de agua ya que sale gota a gota y pasa directamente al suelo, siendo casi nada el agua que se evapora.

- Realiza un aporte de agua más constante (poca cantidad pero riegos más juntos), lo que reduce el estrés hídrico que pueden sufrir las plantas por diferencias en la cantidad de agua disponible en la zona de las raíces.

- Se adapta a cualquier clase de cultivo, pues la cantidad de agua aportada se programa en función de las necesidades de cada grupo de plantas y, además, está a ras de suelo por lo que no interfiere con el espacio de las plantas.

- No necesita que se realicen movimientos de tierra, como es el caso de otros sistemas como el de tuberías enterradas.

- Es más cómodo y menos trabajoso que cualquier sistema manual, lo que implica un importante ahorro de tiempo.

- Minimiza el lavado de nutrientes en el sustrato que se produce cuando el agua de riego los arrastra hacia abajo. Con el riego por goteo, tanto la velocidad del agua como la cantidad son demasiado bajas como para favorecer la pérdida de nutrientes. 


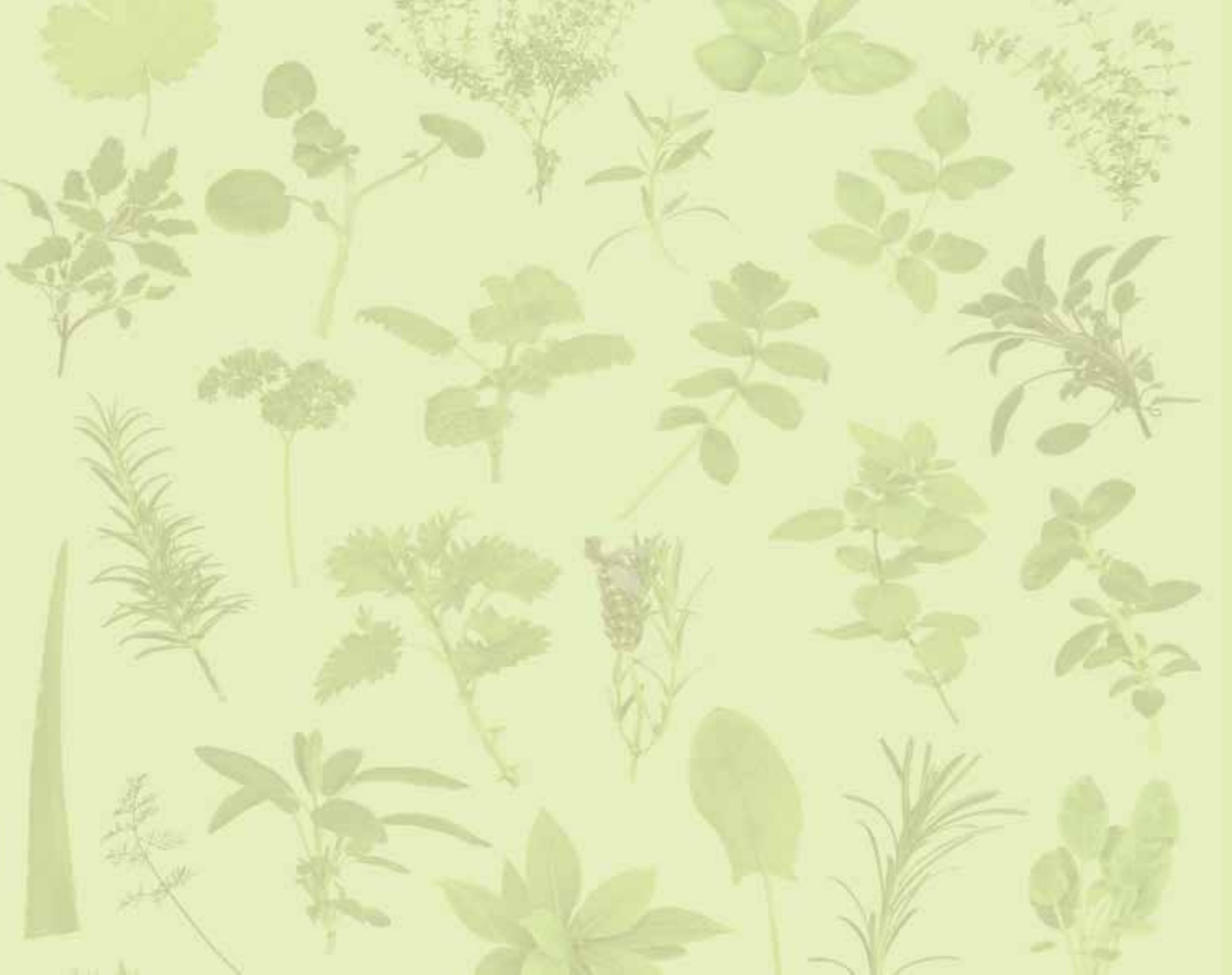




\section{CAPÍTULO 3.}

\section{LA HUERTA ORGÁNICA}

Es un sistema de cultivo de una explotación agrícola autónoma, basada en la utilización óptima de los recursos naturales dándole énfasis a la fertilidad del suelo y la actividad biológica y al mismo tiempo, al no uso de fertilizantes y plaguicidas sintéticos para proteger el ambiente y la salud humana.

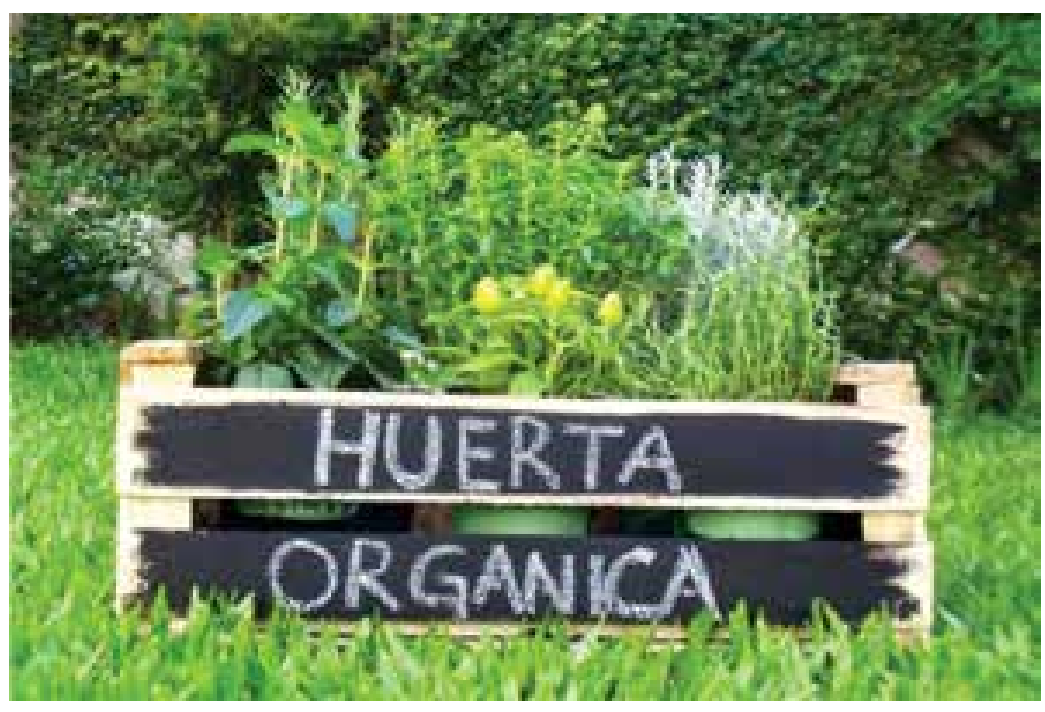

Figura 17. La huerta orgánica.

Fuente. Programa de capacitación. San Isidro. Argentina. 2007

La agricultura ecológica, orgánica o biológica, es un sistema de agricultura basada en la utilización de recursos naturales. Esta agricultura no permite el uso de productos químicos u organismos genéticamente modificados (ni para abono, ni para plagas, ni para semillas) para así conservar la fertilidad de la tierra y respetar el medio ambiente de una forma sostenible y equilibrada. Según Sofía Villa, miembro del colectivo Línea Negra, un colectivo de jóvenes agricultores orgánicos de Bogotá, el principal objetivo de la agricultura orgánica es "mejorar la sustentabilidad integral de la tierra y constituirse como un sistema ecológico y social para combatir la pobreza desde la auto sustentación".

El cultivo ecológico debe estar basado en métodos preventivos, potenciando el buen desarrollo de las plantas y por tanto su resistencia natural a plagas y enfermedades.

Según el INTA (Instituto Nacional de Tecnología Agrícola de la Argentina), la huerta orgánica es una forma natural y económica de producir hortalizas sanas durante todo el año.

Para que la huerta sea productiva durante todo el año se necesita un buen trabajo de la tierra y respetar estos tres principios fundamentales:

- Asociaciones de plantas: Plantar juntas aquellas plantas que por un motivo $u$ otro se toleren entre sí. Por ejemplo: Asociación benéfica: Albahaca, berenjena, escarola, fresas, lechuga, nabo, pepino, pimiento, remolacha, tomate, zanahoria. Asociación perjudicial: Col, leguminosas (guisante, haba, judía) y puerro. 


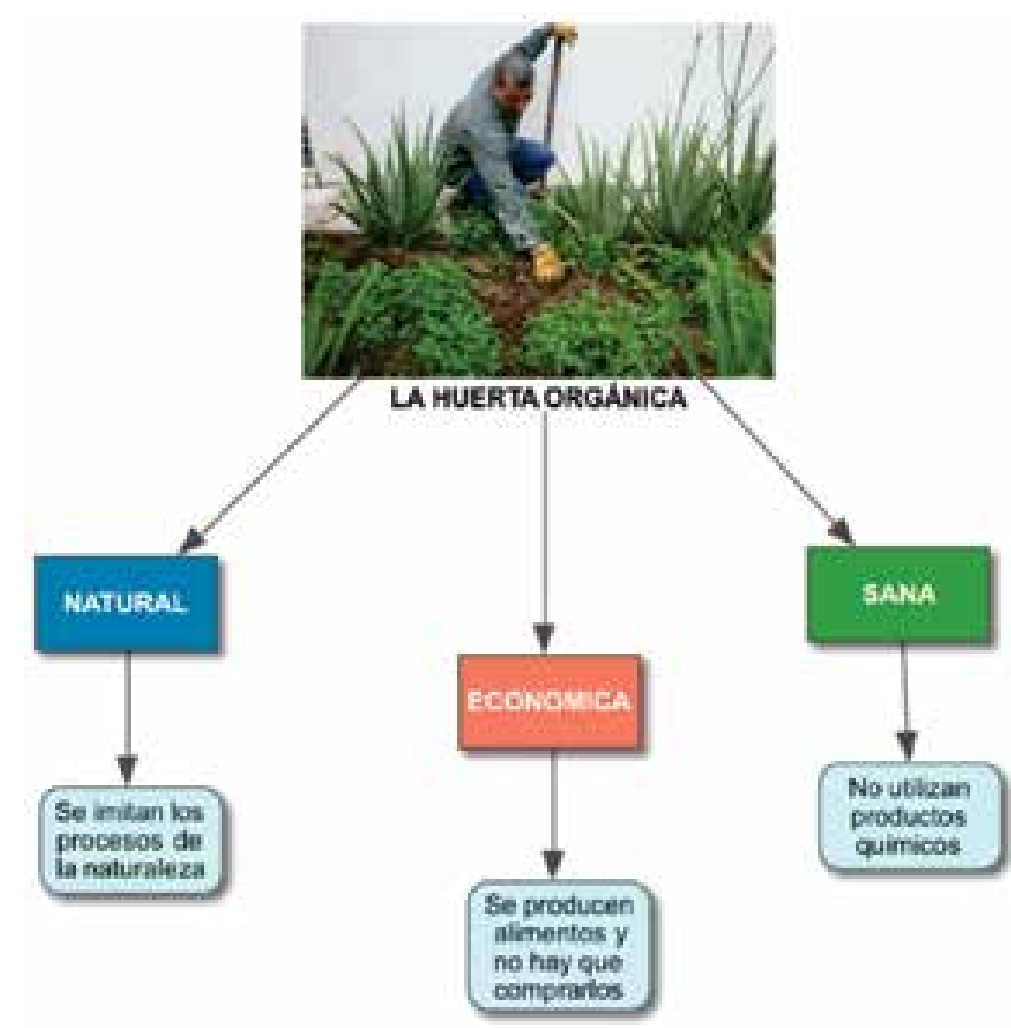

Figura 18. Ventajas de la huerta orgánica. Fuente: Chalela, G. Diagrama propio 2016

- Rotación adecuada: alternar adecuadamente distintos cultivos en el tiempo.

- Abonos orgánicos. Forma de mantener la fertilidad a la tierra gracias a los altos valores nutricionales que componen estos bioabonos.

Además una huerta requiere:

- Buena exposición al sol.
- Cerco perimetral.

- Fuente de agua cercana.

- Semillas certificadas.

En Colombia, según Plaza Capital, una buena parte de los alimentos orgánicos se vende a través de las cadenas tradicionales de venta al por menor, entre ellas el Éxito, Carulla y Pomona, las tres cadenas del grupo Casino (transnacional Francesa) que se ha convertido en líder del mercado y cuenta con cerca del $40 \%$ del negocio de venta en Colombia. Taeq es la marca comercial del Éxito para "productos innovadores y modernos", bajo Taeq Orgánico, el Éxito ofrece una pequeña gama de alimentos ecológicos, principalmente verduras. Es claro entonces que los cultivos orgánicos constituyen una opción de vida sana y autosostenible.

Y es cierto. Debido al cuidado en la producción y conservación para la venta del producto, los agricultores son muy exigentes con los precios de oferta. El tiempo dedicado y el oficio de la agricultura orgánica son mucho más rigurosos que en la agricultura tradicional lo cual influye en los precios de venta.

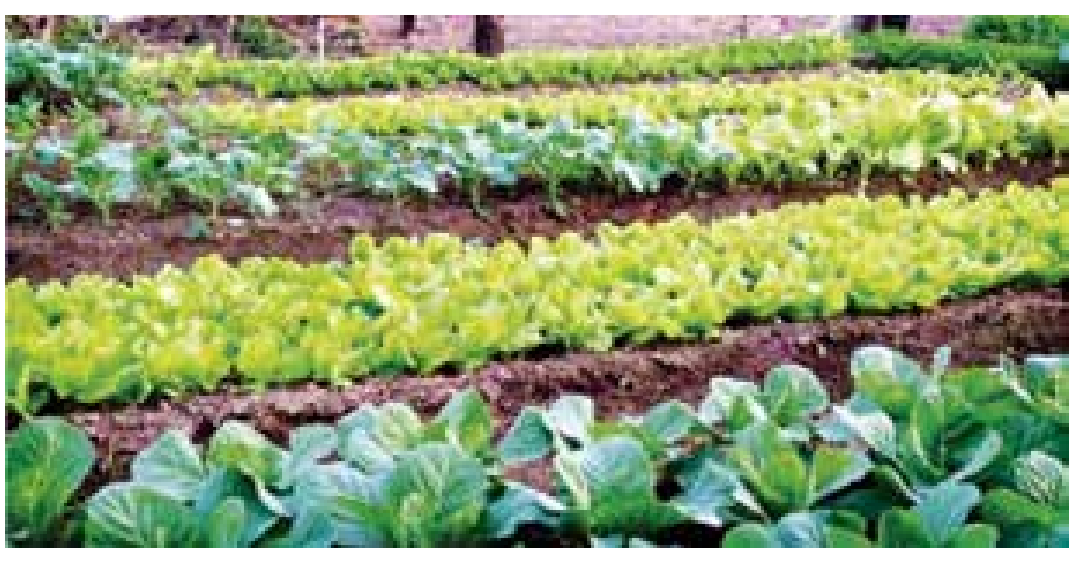

Figura 19. Huerta orgánica productiva. Fuente: Chalela, G. Foto Archivo personal. 2015 


\section{HUERTA URBANA}

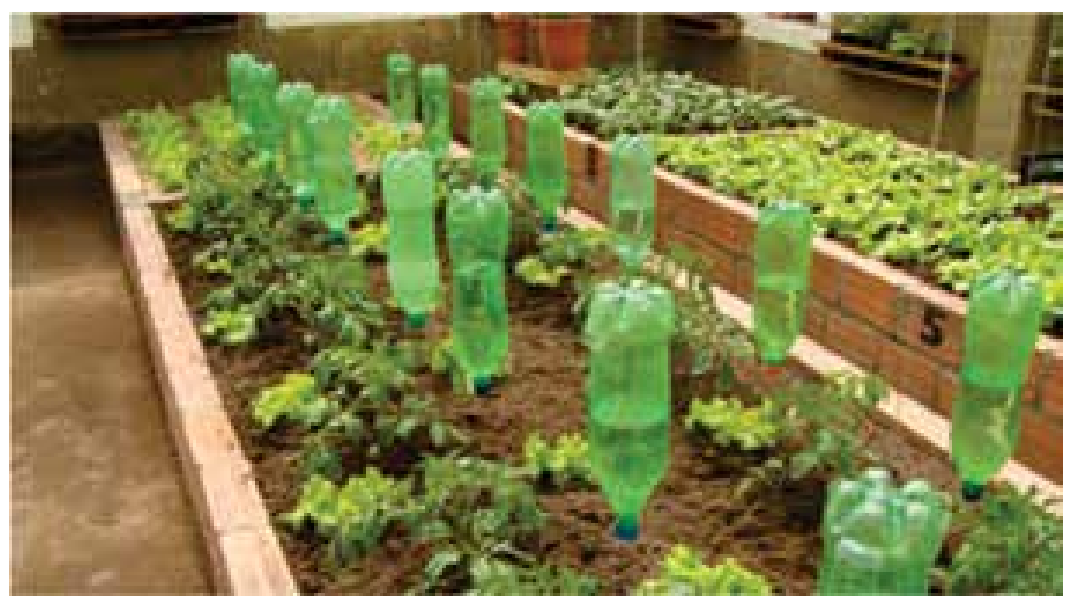

Figura 20. Huerta urbana en un balcón.

Fuente: Internet, 2016

Se trata de espacios cubiertos o no para el cultivo de flores, hortalizas, frutales, aromáticas etc. a escala domestica (reducida), sin que por ello se menosprecie la calidad de los productos obtenidos en la producción.

La Huerta Urbana se puede tener en zonas habitadas para tal fin, ya sea en zonas residenciales de la ciudad, en la propia casa dentro del jardín, en la terraza, en el balcón o en el ático (espacio habitable ubicado directamente debajo de la azotea de un edificio)

Lo habitual es que la agricultura urbana esté destinada a la obtención de alimentos frescos. Al tener acceso inmediato a cultivos, quienes viven en las ciudades incrementan su seguridad alimentaria, ya que no dependen solo de las materias primas que llegan desde la zona rural.
La agricultura natural urbana pone en contacto a los alimentos de manera directa y acerca las raíces culturales, abriéndo a un abanico de alimentos saludables.

Todo lo anterior, repercute positivamente en la estética de la ciudad, los microclimas de las calles y viviendas, la salud y estado de ánimo de los ciudadanos, reduciendo el desperdicio energético y ayudando a reducir los contaminantes en el aire

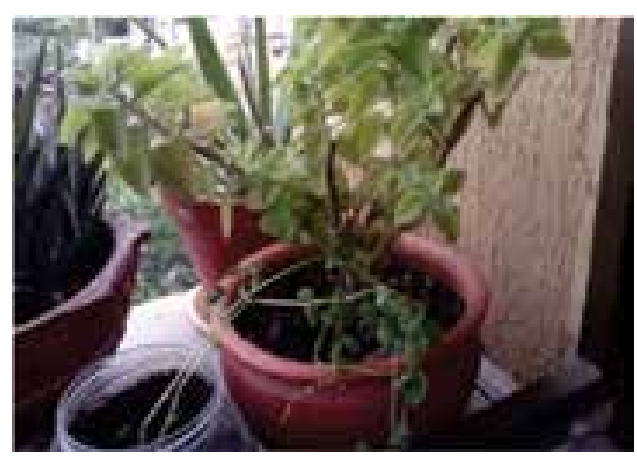

Figura 21. Producción de orégano en materas sobre las ventanas de la casa. Fuente: Mogotocoro, A. Foto Berlín. Santander

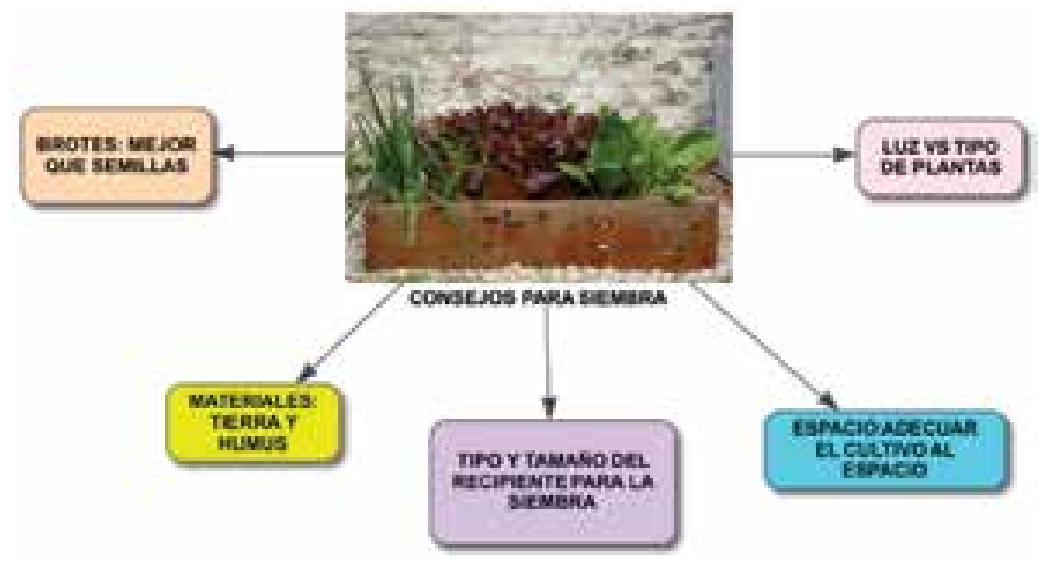

Figura 22. Consejos para la siembra en la huerta urbana. Fuente: Chalela, G. Diagrama propio, 2016 
La agricultura urbana se ha implementado como una estrategia para combatir los problemas de inseguridad alimentaria y nutricional que afectan a países en todo el mundo. Colombia ha sido uno de los países que propone la agricultura urbana como un complemento a la agricultura rural convencional con el objetivo prioritario de ayudar a disminuir la desnutrición y mejorar la salud de las personas.

Con la creación de las huertas urbanas para el autoabastecimiento alimenticio, se pretende que las poblaciones vulnerables con bajos ingresos económicos puedan cultivar alimentos frescos y de buena calidad en su hogar.

Según la Organización Mundial de la Salud (OMS), la alimentación deficiente en frutas, verduras y hortalizas ricas en vitaminas y minerales esenciales es una de las principales causas de las enfermedades no transmisibles más importantes como las cardiovasculares, los trastornos digestivos, la diabetes de tipo 2, determinados tipos de cáncer, y enfermedades neurodegenerativas. Estas enfermedades contribuyen sustancialmente a la carga mundial de morbilidad, mortalidad y discapacidad; la mayoría relacionados con problemas de inseguridad alimentaria que afectan en mayor proporción a países de África, Asia y América latina. Entre estos países se encuentra Colombia, donde solo el $20,5 \%$ de los colombianos consumen frutas tres o más veces al día y únicamente tres de cada diez personas consumen todos los días verduras y hortalizas, entre ellas, solo el 6,4\% lo hacen dos o más veces.

La agricultura urbana se justifica y entiende mejor si se tiene claro el concepto de seguridad alimentaria, la cual se ha definido de muchas maneras pero todas tienen un concepto en común, que el diccionario de la acción humanitaria define de esta manera: "Acceso físico, económico y social a los alimentos necesarios en cantidad, calidad nutricional, seguridad y preferencia cultural, para una vida activa y saludable, por todos los miembros de la familia, en todo momento y sin riesgo previsible de perderlo". (Diccionario de la acción humanitaria y la cooperación al desarrollo 2005-2006).
Para que exista la seguridad alimentaria se deben cumplir cuatro conceptos:

1. Disponibilidad de alimentos en cantidades suficientes y de calidad adecuada, suministrados a través de la producción o importación del país.

2. Acceso a los alimentos y recursos adecuados a los que se tienen derecho para adquirir alimentos apropiados y una alimentación nutritiva.

3. Utilización de los insumos no alimentarios como: agua potable, sanidad y atención médica, para lograr un estado de bienestar nutricional.

4. Estabilidad en el suministro de alimentos en cuanto a la disponibilidad y acceso de una población, un hogar o una persona.

Finalmente, aclaremos algunos conceptos:

La agricultura es el conjunto de técnicas y conocimientos para cultivar la tierra, siendo el sector económico más amplio del mundo y la actividad que requiere mayores porciones de tierra y crecientes recursos para su producción (agua, fertilizantes, etc.), por estas razones la agricultura juega un papel importante en la trasformación del medio ambiente. La agricultura respondiendo a estas transformaciones se divide en diferentes tipos de agricultura dependiendo de sus impactos económicos, sociales y medioambientales, además de su técnica.

La agricultura intensiva: es la forma de cultivo propio de gran presión demográfica, en donde se obtienen varias cosechas al año, a base de grandes cantidades de abono, plaguicidas y fertilizantes, en poca extensión de tierra.

La agricultura orgánica: es el proceso que utiliza técnicas y métodos que respetan el medioambiente desde las etapas de producción hasta la manipulación y procesamiento, ocupándose no solo del producto sino de todo el sistema de producción. 
La agricultura industrial: es el cultivo de un solo producto (monocultivo), en donde hay un alto nivel de tecnificación, y se requiere una gran inversión de capital, energía y recursos tales como terrenos, mano de obra y maquinaría especializada.

La agricultura urbana $(A U)$ según la $F A O$ se refiere a pequeñas superficies que se encuentran dentro de la ciudad y están especialmente destinadas a la producción menor de cultivos agrícolas o ganado para la venta o el consumo propio. La agricultura periurbana (AUP), es una categoría de la agricultura urbana y también hacer referencia la producción de hortalizas y productos hortícolas pero que se encuentran cercanas a la ciudad. (FAO, 1999) La diferencia entre las zonas urbanas y periurbanas depende de la densidad de la población, los límites de tierra que se hayan establecido en la ciudad y el comportamiento de los habitantes

La diferencia entre la agricultura convencional (rural) y la agricultura urbana no solo radica en la zona en la que se realiza ni en la extensión de tierra que utiliza, también incluye condiciones variables como:

- Acceso a los mercados de consumo, en un menor tiempo.

- Menor necesidad de envasar, almacenar y transportar los alimentos;

- Acceso de los consumidores pobres a los alimentos por medios distintos del mercado;

- Disponibilidad de alimentos frescos y perecederos;

- Proximidad a los servicios, incluidas las instalaciones de tratamiento de desechos;

- Posibilidades de recuperación y reutilización de desechos.

- La Agricultura Urbana no representa competencia directa de la agricultura rural, pues es más bien una práctica complementaria.
La Agricultura Urbana posee una ventaja comparativa gracias a que satisface las necesidades del mercado urbano que deben abastecerse de aquellos lugares en donde los sistemas de transporte y aprovisionamiento de la explotación agrícola hacia el mercado son deficientes o exigen costos elevados que dificultan que las comunidades con bajos ingresos no puedan adquirirlos, provisionando alimentos frescos y perecederos a estos mercados y en adición, las zonas descentralizadas de producción rural son también esenciales para alimentar a las ciudades.

\section{EL COMPOSTAJE}

El compostaje es un proceso de reciclaje y trasformación de la materia orgánica para obtener un abono natural, compost.

El compostaje se obtiene de manera natural por descomposición oxigénica, es decir, en presencia de oxigeno utilizando como materia prima residuos. El compost o mantillo se puede definir como el resultado de un proceso de humificación de la materia orgánica, bajo condiciones controladas y en ausencia de suelo. El compost es un nutriente para el suelo que mejora la estructura y ayuda a reducir la erosión y permite a la absorción de agua y nutrientes por parte de las plantas.

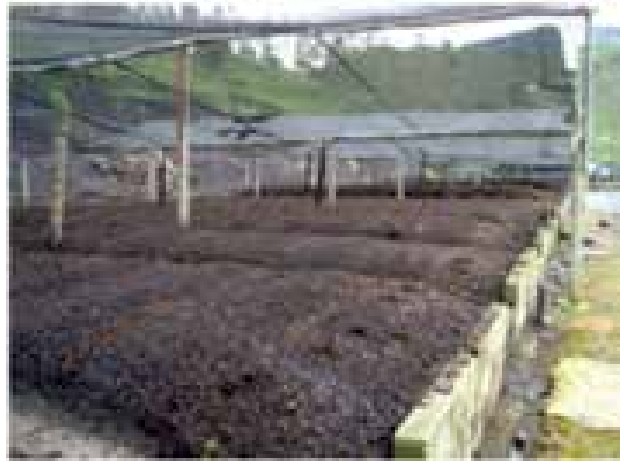

Figura 24. Compost a partir de residuos sólidos orgánicos vegetales.

Fuente: Chalela, G. Foto archivo, 2014 
El compostaje ha sido practicado desde la Antigüedad. Desde hace miles de años, los chinos han recogido y compostado todas las materias de sus jardines, de sus campos y de sus casas, incluyendo materias fecales. En las puertas de Jerusalén. Por ejemplo, había lugares dispuestos para recoger las basuras urbanas: unos residuos se quemaban y con los otros se hacía compost. El descubrimiento, después de la Primera Guerra Mundial, de los abonos de síntesis populariza su utilización en la agricultura. De forma tradicional, durante años, los agricultores han reunido los desperdicios orgánicos para transformarlos en abono para sus tierras. Compostar dichos restos no es más que imitar el proceso de fermentación que ocurre normalmente en un suelo de un bosque, pero acelerado y dirigido. El abono resultante proporciona a las tierras a las que se aplica, prácticamente los mismos efectos beneficiosos que el humus para una tierra natural.

El desarrollo de la técnica de compostaje a gran escala tiene su origen en la India con las experiencias llevadas a cabo por el inglés Albert Howard entre 1905 a 1947. Su éxito consistió en combinar sus conocimientos científicos con los tradicionales de los campesinos. Su método, llamado método Indore, se basaba en fermentar una mezcla de desechos vegetales $y$ excrementos animales, y humedecerla periódicamente.

La palabra compost viene del latín "componere", juntar; por lo tanto es la reunión de un conjunto de restos orgánicos que sufre un proceso de fermentación y da un producto de color marrón oscuro; en este momento se puede decir que el proceso de fermentación está esencialmente finalizado. El abono resultante contiene materia orgánica así como nutrientes del tipo del nitrógeno, fósforo, potasio, magnesio, calcio y hierro, necesarios para la vida de las plantas.

\section{Propiedades del compost}

- Mejora las propiedades físicas del suelo. La materia orgánica favorece la estabilidad de la estructura de los agregados del suelo agrícola, reduce la densidad aparente, aumenta la porosidad y permeabilidad, y aumenta su capacidad de retención de agua en el suelo. Se obtienen suelos más esponjosos y con mayor retención de agua.

- Mejora las propiedades químicas. Aumenta el contenido en macronutrientes $\mathrm{N}, \mathrm{P}, \mathrm{K}, \mathrm{y}$ micronutrientes, la capacidad de intercambio catiónico (C.I.C.) y es fuente y almacén de nutrientes para los cultivos.

- Mejora la actividad biológica del suelo. Actúa como soportey alimento de los microorganismos ya que viven a expensas del humus y contribuyen a su mineralización.

- La población microbiana es un importante indicador de la fertilidad del suelo.

\section{Las materias primas del compost.}

Para la elaboración del compost se puede emplear cualquier materia orgánica, con la condición de que no se encuentre contaminada. Generalmente estas materias primas proceden de:

$\checkmark$ Restos de cosechas. Pueden emplearse para hacer compost o como acolchado. Los restos vegetales jóvenes como hojas, frutos, tubérculos, etc son ricos en nitrógeno y pobres en carbono. Los restos vegetales más adultos como troncos, ramas, tallos, etc son menos ricos en nitrógeno.

$\checkmark$ Abonos verdes, siegas de césped, malas hierbas, etc. 
$\checkmark \quad$ Las ramas de poda de los frutales. Es preciso triturarlas antes de su incorporación al compost, ya que con trozos grandes el tiempo de descomposición se alarga.

$\checkmark$ Hojas. Pueden tardar de 6 meses a dos años en descomponerse, por lo que se recomienda mezclarlas en pequeñas cantidades con otros materiales.

$\checkmark$ Restos urbanos. Se refiere a todos aquellos restos orgánicos procedentes de las cocinas como pueden ser restos de fruta y hortalizas, restos de animales de mataderos, etc.

$\checkmark$ Estiércol animal. En especial el estiércol de vaca; existiendo otros de gran interés como la gallinaza, conejina, estiércol de caballo, de oveja y los purines que son los estiércoles líquidos del sector porcino, compuestos por deyecciones, aguas de lavado y restos de alimentos.

$\checkmark$ Complementos minerales. Son necesarios para corregir las carencias de ciertas tierras. Destacan las enmiendas calizas y magnésicas, los fosfatos naturales, las rocas ricas en potasio y oligoelementos y las rocas silíceas trituradas en polvo.

$\checkmark \quad$ Plantas marinas. Anualmente se recogen en las playas grandes cantidades de fanerógamas marinas como Posidonia oceánica, que pueden emplearse como materia prima para la fabricación de compost ya que son compuestos ricos en $\mathrm{N}, \mathrm{P}, \mathrm{C}$, oligoelementos y biocompuestos cuyo aprovechamiento en agricultura como fertilizante verde puede ser de gran interés.

$\checkmark \quad$ Algas. También pueden emplearse numerosas especies de algas, ricas en agentes antibacterianos y antifúngicos y fertilizantes para la fabricación de compost.

\section{Factores que condicionan el proceso de compostaje}

Como se ha comentado, el proceso de compostaje se basa en la actividad de microorganismos que viven en el entorno, ya que son los responsables de la descomposición de la materia orgánica. Para que estos microorganismos puedan vivir $y$ desarrollar la actividad descomponedora se necesitan unas condiciones óptimas de temperatura, humedad y oxigenación.

Son muchos y muy complejos los factores que intervienen en el proceso biológico del compostaje, estando a su vez influenciados por las condiciones ambientales, tipo de residuo a tratar y el tipo de técnica de compostaje empleada. Los factores más importantes son:

Temperatura. Se consideran óptimas las temperaturas del intervalo 35-55 ㅇ p para conseguir la eliminación de patógenos, parásitos y semillas de malas hierbas. A temperaturas muy altas, muchos microorganismos interesantes para el proceso mueren y otros no actúan al estar endosporados.

Humedad. En el proceso de compostaje es importante que la humedad alcance unos niveles óptimos del 40-60\%. Si el contenido en humedad es mayor, el agua ocupará todos los poros y por lo tanto el proceso se volvería anoxigénico, es decir se produciría una putrefacción de la materia orgánica. Si la humedad es excesivamente baja se disminuye la actividad de los microorganismos y el proceso es más lento. El contenido de humedad dependerá de las materias primas empleadas. Para materiales fibrosos o residuos forestales gruesos la humedad máxima permisible es del 75-85\% mientras que para material vegetal fresco, ésta oscila entre $50-60 \%$.

pH. Influye en el proceso debido a su acción sobre microorganismos. En general los hongos toleran un margen de 
$\mathrm{pH}$ entre 5-8, mientras que las bacterias tienen menor capacidad de tolerancia ( $\mathrm{pH} 6-7,5)$

Oxígeno. El compostaje es un proceso oxigénico, por lo que la presencia de oxígeno es esencial. La concentración de oxígeno dependerá del tipo de material, textura, humedad, frecuencia de volteo y de la presencia o ausencia de aireación forzada.

Relación equilibrada de $\mathbf{C} / \mathbf{N}$. El carbono y el nitrógeno son los dos constituyentes básicos de la materia orgánica. Por ello para obtener un compost de buena calidad es importante que exista una relación equilibrada entre ambos elementos. Teóricamente una relación $\mathrm{C} / \mathrm{N}$ de 25-35 es la adecuada, pero esta variará en función de las materias primas que conforman el compost. Si la relación $\mathrm{C} / \mathrm{N}$ es muy elevada, disminuye la actividad biológica.

Una relación $\mathrm{C} / \mathrm{N}$ muy baja no afecta al proceso de compostaje, perdiendo el exceso de nitrógeno en forma de amoniaco. Es importante realizar una mezcla adecuada de los distintos residuos con diferentes relaciones $\mathrm{C} / \mathrm{N}$ para obtener un compost equilibrado. Los materiales orgánicos ricos en carbono y pobres en nitrógeno son la paja, el heno seco, las hojas, las ramas, la turba y el serrín. Los pobres en carbono y ricos en nitrógeno son los vegetales jóvenes, las deyecciones animales y los residuos de matadero.

Población microbiana. El compostaje es un proceso aeróbico de descomposición de la materia orgánica, llevado a cabo por una amplia gama de poblaciones de bacterias, hongos pertenecientes a diferentes grupos..

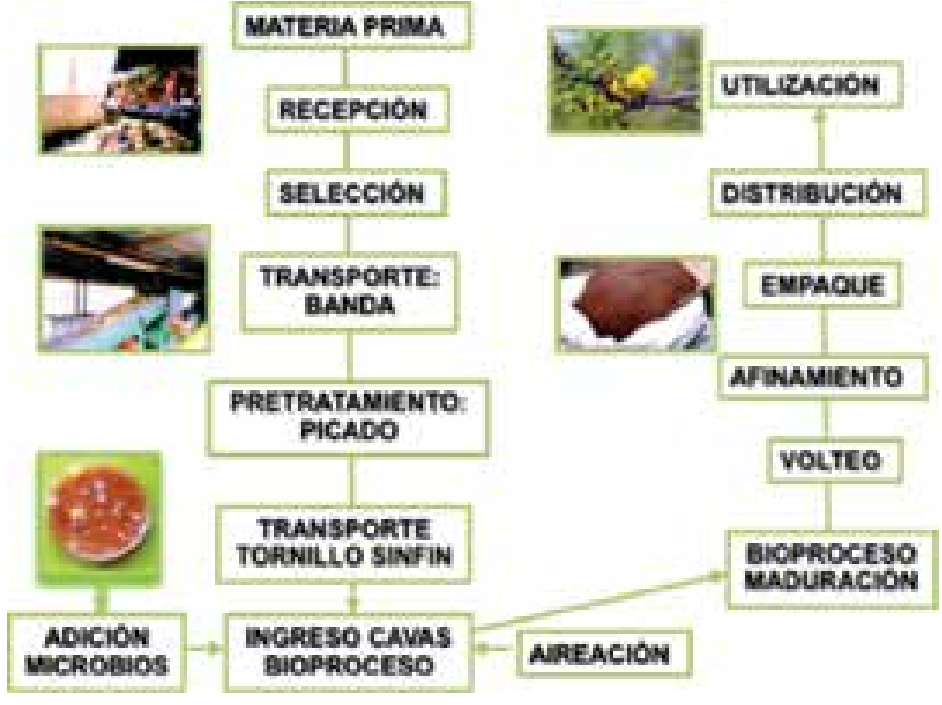

Figura 25. Producción de biocompost. Fuente: Chalela, G. Diagrama propio, 2012

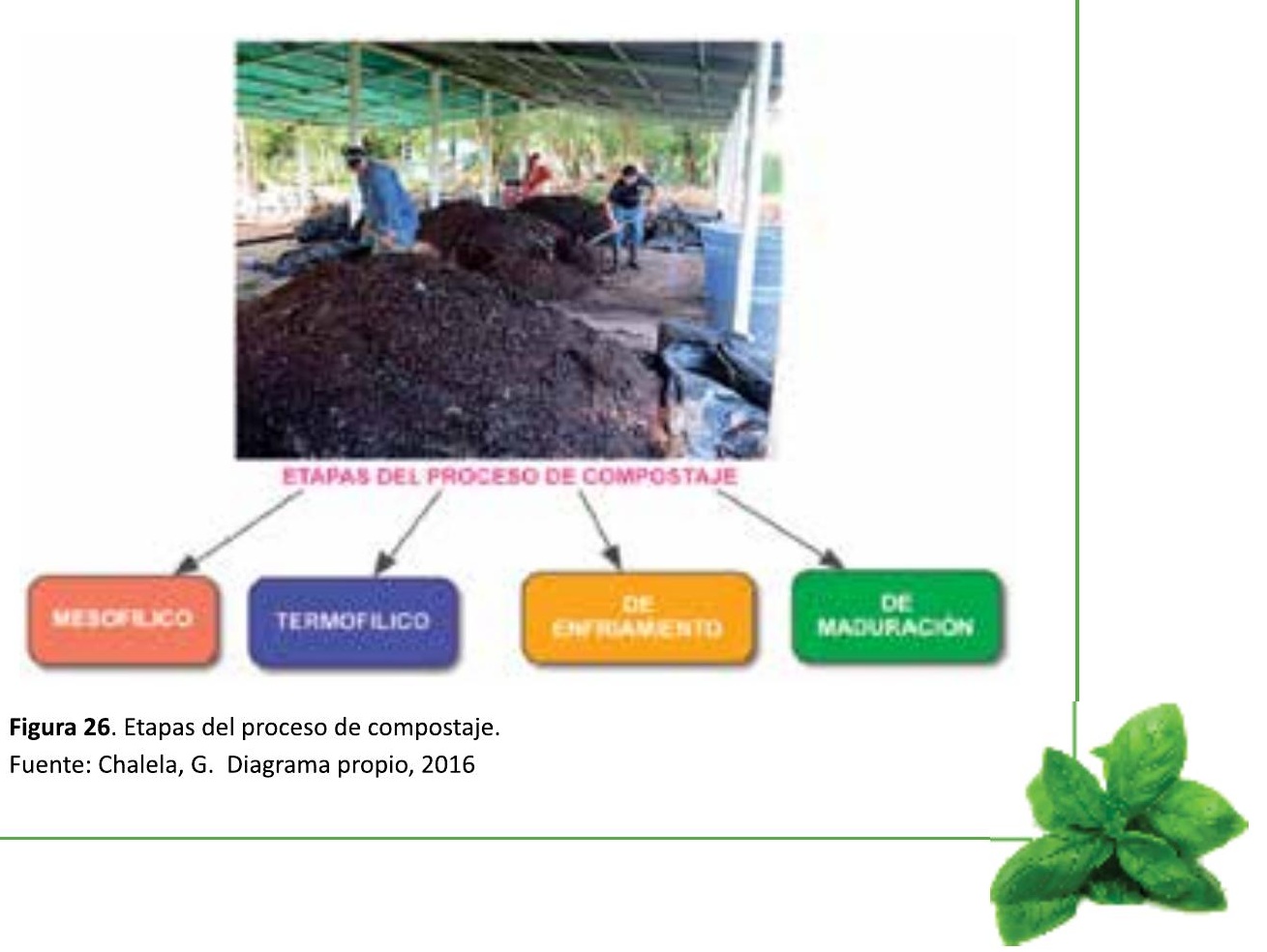




\section{PREPARADOS FITOTERAPÉUTICOS}

Según el artículo 2 del Decreto 2266 de 2004 de Colombia, un preparado fitoterapéutico "Es el producto medicinal empacado y etiquetado, cuyas sustancias activas provienen de material de la planta medicinal o asociaciones de éstas, presentado en estado bruto o en forma farmacéutica que se utiliza con fines terapéuticos. También puede provenir de extractos, tinturas o aceites. No podrá contener en su formulación principios activos aislados y químicamente definidos. Los productos obtenidos de material de la planta medicinal que haya sido procesado y obtenido en forma pura no será clasificado como producto fitoterapéutico".

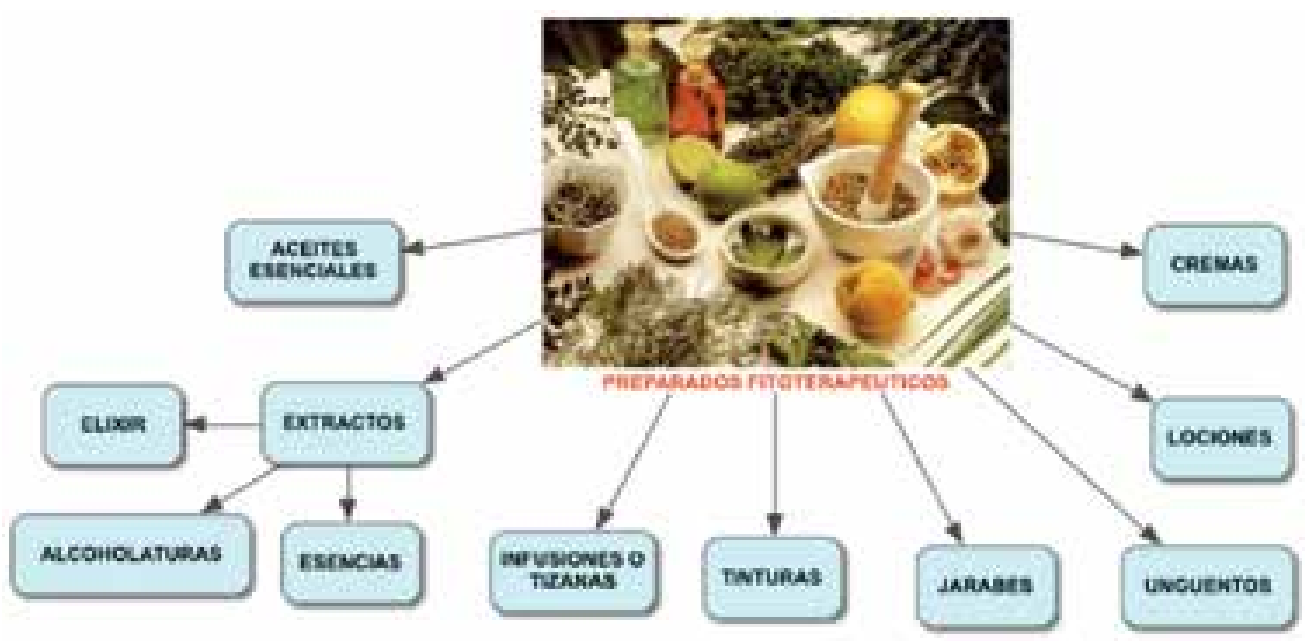

Figura 27: Clasificación de los preparados fitoterapéuticos

Fuente: Chalela, G. Diagrama propio, 2016

\section{EXTRACTOS}

Son sustancias que se extraen de la planta seca y que en forma concentrada, poseen su virtud característica. Son básicamente preparados farmacéuticos por lo que su fabricación y envasado se realiza en laboratorios especializados. De manera informativa equivale a preparar un jugo, en el que se adiciona agua destilada $u$ otro medio y las plantas medicinales. Según Thomson, se consideran tres tipos de extractos:

- Los extractos fluidos que son aquellos en los que el volumen del líquido del extracto es igual al volumen de la planta seca que se haya usado.

- Los extractos blandos son a los que se les ha retirado el agua parcialmente hasta tener una consistencia de ungüento

- Los extractos secos que son a los que se les ha retirado en su totalidad el agua y su, apariencia es la de un polvo muy fino.

En fitoterapia se mezclan distintos extractos para obtener la terapia medicinal deseada y se suelen presentar en forma de elixires, esencias y alcoholaturas.

- Elixir: Licor compuesto de varias sustancias medicinales disueltas generalmente en alcohol. 
- Esencia: Sustancia volátil, olorosa, poco soluble en el agua, extraída de algunos vegetales. Las esencias se llaman también aceites etéreos, esenciales o volátiles.

- Alcoholaturas: Líquido que se obtiene macerando plantas frescas en alcohol.

Algunos de ejemplos de preparados:

Extracto de vainilla: utiliza al menos 2 vainas de vainilla por cada $1 / 2$ taza de vodka. Corta las vainas por la mitad, a lo largo para abrirlas con cuidado de que no se caigan las semillas. Meterlas en un frasco con tapa que cierre bien (o hermético) con 1/2 taza de vodka y guardarlo en un lugar fresco y seco resguardado de la luz, durante 8 semanas. Agitar el frasco una vez a la semana.

Extracto de avellanas: se utiliza 1 taza de avellanas tostadas o 1 taza de avellanas crudas y se tuestan al horno o en la sartén. Por cada taza de avellanas se pone 1 taza de vodka. Dejarlo guardado durante 3-4 semanas antes de usarlo. Agitarlo 1 vez a la semana.

Extracto de almendras: utiliza 1 taza de almendras naturales o tostadas por cada taza de vodka. Al igual que el extracto de avellanas se puede empezar a usar después de 3-4 semanas.

Extracto de café: mezclar 2 cucharadas de granos de café rotos o machacados con $1 / 2$ taza de agua y $1 / 2$ de vodka durante 6-8 semanas, agitándolo 1 vez a la semana.

Extracto de canela: utiliza 2 ramitas de canela por cada $1 / 2$ taza de vodka. Tras 1 semana puede empezar a usarse.

Extracto de naranja: colocar en un frasco hermético la cáscara de 2 naranjas (lavadas, pelalas con un pelador de verduras procurando que lleve poca parte blanca) con $1 / 4$ de taza de agua y $1 / 4$ de taza de vodka. Guardarlo cerrado 1 semana antes de usarlo. Agitarlo antes de usar.
Extracto de menta: frotar entre las manos $1 / 2$ taza de menta fresca (lavada), para que expulse más aromas, y guardarla con $1 / 2$ taza de vodka y $1 / 4$ de agua. Dejar reposar por 6 semanas, agitándolo una vez a la semana, antes de usarlo.

Extracto de estevia (Estevia rebaudiana: utilizar al menos $1 / 2$ taza de hojas de estevia y $1 / 2$ de vodka o ron blanco (lo justo para cubrirlas por completo). Dejar reposar 3-4 días. Colar el líquido por un colador, añadir 1/4 de taza de agua y cocinarlo a fuego lento 15-25 minutos (depende de la cantidad, si es con $1 / 2$ taza de estevia, entre 15 y 20 minutos), sin que llegue nunca a hervir (si hierve no quedará dulce). Dejar enfriar y guardar bien cerrado para usar cuando se requiera.

Si se utiliza planta seca, el extracto vegetal puede durar hasta 5 años, si se utiliza planta fresca, el extracto vegetal, cuanto más agua tenga la materia vegetal y menor sea la graduación del alcohol, se conservará menos tiempo lo que puede ser semanas, meses o años. Los extractos herbales que contienen glicerina vegetal pueden durar de uno a tres años y los de extractos herbales de vinagre de manzana duran no más de 6 meses. Si se desea una conservación mayor, pruebe guardarlo en la nevera.

Todos los órganos vegetales contienen cantidades variables de sustancias potencialmente alelopáticas que son liberadas de diferentes formar al medio ambiente mediante volatilización, exudación radicular, lixiviación y descomposición de residuos vegetales.

\section{TINTURAS}

Consiste en la extracción de los principios activos por medio de alcohol etílico, éter, mezcla de ambas, licores o vinos, vodka, ginebra entre otros. Pueden disolverse en agua, jugo de frutas (sin leche) o endulzarlas con miel. Las tinturas se obtienen por: 
- Remojo: Durante varias semanas, agitación constante: 125 g de material seco ó $300 \mathrm{~g}$ de material fresco por medio litro de una mezcla $25 \%$ agua-alcohol.

- Maceración: Con mortero o piedra y luego se mezcla con el alcohol o el licor.

Finalmente, decantar, filtrar y envasar.

Precauciones: En buenas condiciones de almacenamiento las tinturas pueden durar hasta 2 años.

Observar especial cuidado en niños, personas diabéticas, alcohólicas y embarazadas. Las afecciones hepáticas no deben ser tratadas con este método. Se pueden preparar en frío o en caliente, en proporción de $500 \mathrm{~mL}$ aceite por $250 \mathrm{~g}$ de material vegetal seco ó $750 \mathrm{~g}$ de material vegetal fresco en frío con un aceite de buena calidad como ajonjolí, uva, oliva, germen de trigo, otros. Se agita diariamente durante mínimo un mes y medio. Repetir utilizando nuevo material vegetal y el aceite de infusión ya preparado.

En caliente: Similar al anterior pero más adecuado para plantas carnosas. Se coloca aceite vegetal con hierbas secas en baño maría, durante un período de tres horas a fuego lento. Reposar y envasar.

\section{INFUSIÓN, TISANA O AGUA AROMÁTICA}

Infusión: se coloca la planta en un recipiente y se adiciona agua casi en el punto de ebullición (no hirviendo).Colar y consumir. Dosis: $2,5 \mathrm{~g}$ de planta seca en 1 taza de agua.

Tisana: Se hierve el agua previamente durante 5 minutos, se agrega la planta y se deja hervir durante 5 minutos más. Colar y consumir. Importante: Mantener el recipiente tapado durante todo el proceso.
Decocción: es una forma más fuerte de obtener los principios activos de la planta. Se colocan 2 cucharaditas de hierba seca por taza de agua, y se deja hervir hasta reducir a una tercera parte del volumen inicial. Colar y consumir. Los extractos, las decocciones y las infusiones, también se pueden utilizar para preparar compresas y emplastos.

\section{JARABES}

Son una forma de conservar las infusiones y las decocciones añadiéndole miel o azúcar, en lo posible sin refinar. Se calienta igual cantidad de infusión que miel, se agita, se disuelve hasta consistencia de almíbar, se deja enfriar y se almacena.

\section{LOCIONES}

Son una mezcla con base en agua que se aplica sobre la piel con el objeto de refrescar o calmar irritaciones. Una mezcla puede incluir: Agua de rosas, tintura de árnica y aceite esencial de lavanda.

\section{UNGÜENTOS}

La base de los ungüentos es la vaselina o la cera de abejas. Al contrario de las cremas no son absorbidos sino que forman una capa protectora. Sirven para tratar heridas, quemaduras, contusiones y derrames. Se calienta la vaselina a baño maría, se añaden las plantas medicinales, se mezcla y se mantiene a fuego lento durante unas tres horas. Se filtra y se envasa.

\section{CREMAS}

A diferencia de los ungüentos las cremas buscan la absorción rápida. Para prepararlas se funde cera mezclada en agua en baño maría, se 
añaden las hierbas y se calientan a fuego lento. Filtrar y remover constantemente hasta que se enfríe (emplear batidora si es necesario)

\section{ACEITES ESENCIALES}

Son formas altamente concentradas de la parte de la planta de la cual se extraen. Consisten en una mezcla de sustancias aromáticas que sólo la naturaleza puede producir. En general, los Aceites Esenciales se definen como mezclas de componentes volátiles, productos del metabolismo secundario de las plantas. Se encuentran muy difundidos en el reino vegetal, de las 295 familias de plantas, de 60 a 80 producen aceites esenciales.

La aromaterapia es la terapia que utiliza aromas que provienen de la naturaleza, plantas, flores, arbustos, con fines curativos. El proceso requiere de la destilación del vegetal para captar lo que se denominan Aceites Esenciales, estos aceites serán los encargados de transmitir las propiedades naturales por medio de aplicaciones y tratamientos.

La facilidad de absorción de la piel permite que los componentes activos penetren directamente en el organismo, mejorando el sistema humano o animal y actuando sobre la circulación sanguínea, los tejidos, los órganos, etc., mejorando las diferentes dolencias tanto físicas como psicológicas.

Además de hidratar y nutrir en superficie, lo más importante de estos Aceites Esenciales son sus virtudes relajantes, tonificantes o descongestivas, captadas al instante por el olfato y que constituyen toda una ciencia curativa: La Aromaterapia.

El potencial de los aceites esenciales tiene una correspondencia directa con la fitoterapia y las propiedades de las plantas medicinales: Contrarrestar el insomnio. Reducir el stress. Disminuir la ansiedad. Aliviar el dolor. Quitar la depresión. Aumentar las defensas inmunológicas. Corregir problemas estomacales crónicos Además se pueden utilizar para higienizar una habitación, ropa o artículos personales de la persona enferma. Evitar contagios. Despejar las vías respiratorias. Aumentar las defensas del organismo. Fluidificar las secreciones. Mejorar el sistema inmune. Calmar la tos y el dolor de garganta.

\section{Formas de aplicación}

Es importante recalcar que los aceites no deben ingerirse nunca, ni aplicarse tampoco directamente sobre la piel. Por eso, se usan siempre diluidos en agua, mezclados con los llamados "aceites base" (aceites neutros) o por difusión en el aire.

Masaje: Uno de los métodos de aromaterapia más eficaces, pues a la eficacia de los aceites esenciales se une el poder terapéutico del masaje. En un aceite base (de almendras dulces o de albaricoque, por ejemplo) se diluye de un $2,5 \%$ a un $5 \%$ de aceite esencial, dependiendo del extracto elegido.

Baño: Se puede agregar varias gotas de aceites esenciales sobre el agua tibia de una bañera y luego sumergirse durante 15 o 20 minutos. Por este medio se aspira tanto el vapor de los aceites esenciales como se permite que estos penetren a través de la piel. Si lo prefiere puede mezclar de 3 a 5 gotas de aceite esencial con tres cucharadas de miel de abeja antes de agregarlo en el agua.

Inhalación: Se agregan algunas gotas en un pañuelo y oler, o se pueden agregar de 6 a 12 gotas en una olla de agua hirviendo y luego se coloca una toalla o manta que cubra tanto la cabeza como la olla y se inhala el vapor durante varios minutos. Se debe tener la precaución de no acercarse demasiado. 
Difusión: Existe en el mercado una amplia variedad de productos para llenar el espacio de una habitación u oficina con el aroma de los aceites esenciales. Estos productos, llamados difusores o atomizadores, esparcen los aceites esenciales formando una nube de diminutas partículas. Estos difusores pueden ser de utilidad en casos de afecciones respiratorias o simplemente para llenar el aire con una fragancia ya sea calmante o estimulante.

Compresas: Estas pueden ser frías o calientes. Se utilizan para aliviar dolores de cabeza, y molestias musculares. Se pueden añadir de 5 a 10 gotas de aceites esenciales a 4 onzas de agua. Se empapa una toalla en esta solución y se aplica al área dolorida.

\section{PRINCIPALES ACEITES ESENCIALES}

Las especies vegetales son la materia prima de los aceites esenciales, que además de reducir el estrés y renovar nuestra energía ayudan a curar otros padecimientos. Entre la amplia gama de aceites -con los cuales se puede preparar baños, compresas, frotaciones, infusiones o simplemente absorber su olor, se nombran a continuación algunos:

\begin{tabular}{|l|l|}
\hline $\begin{array}{c}\text { NOMBRE } \\
\text { DEL } \\
\text { PRODUCTO }\end{array}$ & \multicolumn{1}{c|}{ USO } \\
\hline Algas & $\begin{array}{l}\text { Favorecen al aumento de concentración y generan } \\
\text { interés sobre las actividades de tipo intelectual (leer, } \\
\text { redactar, etc.). }\end{array}$ \\
\hline Anís & $\begin{array}{l}\text { Ayuda a descansar la vista, calma los calambres, gases, } \\
\text { dolores abdominales, dolores menstruales, náuseas y } \\
\text { dolores de garganta; así mismo, por su efecto diurético } \\
\text { evita la retención de líquidos. }\end{array}$ \\
\hline
\end{tabular}

\begin{tabular}{|l|l|}
\hline Albahaca & $\begin{array}{l}\text { Se utiliza para el dolor de cabeza y migrañas, también } \\
\text { para la fatiga mental. }\end{array}$ \\
\hline Angélica & $\begin{array}{l}\text { Carminativo, depurativo, antiespasmódico, } \\
\text { expectorante, digestivo, diurético, emenagogo, tónico, } \\
\text { estomacal y febrífugo. }\end{array}$ \\
\hline Bergamota & $\begin{array}{l}\text { Eleva el espíritu, refresca y relaja. Es muy útil para casos } \\
\text { de depresión, ansiedad y tensión. }\end{array}$ \\
\hline Camomila & $\begin{array}{l}\text { Tensión premenstrual, indigestión, moderadamente } \\
\text { antialérgico, rinitis o polinosis (fiebre del heno), acné, } \\
\text { eczema y otras alteraciones cutáneas. }\end{array}$ \\
\hline Canela & $\begin{array}{l}\text { Problemas circulatorios, diabetes, problemas } \\
\text { respiratorios y gripe, anticoagulantes. }\end{array}$ \\
\hline $\begin{array}{l}\text { Cidrón } \\
\text { (hierba } \\
\text { Luisa) }\end{array}$ & $\begin{array}{l}\text { Relajante y tonificante nervioso. Cardiotónico, } \\
\text { antiespasmódico, contra neuralgias, alergias. }\end{array}$ \\
\hline Ciprés & $\begin{array}{l}\text { Curar várices, actúa sobre el sistema circulatorio, cistitis, } \\
\text { problemas de la próstata, hemorroides, bronquitis, } \\
\text { sinusitis. }\end{array}$ \\
\hline $\begin{array}{l}\text { Eucalipto } \\
\text { olor }\end{array}$ & $\begin{array}{l}\text { Anticoagulante, anestésico, antiinflamatorio, } \\
\text { antibiótico. } \\
\text { Descongestivo, propiedades balsámicas y } \\
\text { la gota, contra la hidropesía. }\end{array}$ \\
\hline Enebro & $\begin{array}{l}\text { Antidepresivo, relajante y para restaurar y estabilizar } \\
\text { emociones. }\end{array}$ \\
\hline Geranio & destimulante emocional. \\
\hline
\end{tabular}




\begin{tabular}{|c|c|}
\hline Jazmín & $\begin{array}{l}\text { Depresión, especialmente la posparto, favorece la } \\
\text { contracción durante el parto, reducir el colesterol, anti } \\
\text { coágulos sanguíneos, antioxidante. }\end{array}$ \\
\hline Jengibre & $\begin{array}{l}\text { Dolores reumáticos y musculares, anti mareo, } \\
\text { congestión nasal, gripe. }\end{array}$ \\
\hline Lavanda & $\begin{array}{l}\text { Es un sedante muy efectivo, se utiliza en problemas de } \\
\text { insomnio. Ayuda a balancear estados emocionales como } \\
\text { depresiones, calma, relaja, contra el insomnio, combate } \\
\text { la caspa, previene la caída del cabello. }\end{array}$ \\
\hline Limón & $\begin{array}{l}\text { Contra la hipertensión, antiséptico, astringente, } \\
\text { cicatrizante, ayuda a bajar de peso. }\end{array}$ \\
\hline Mandarina & $\begin{array}{l}\text { Antioxidante, reduce el colesterol, antigripal, previene la } \\
\text { anemia, sedante. }\end{array}$ \\
\hline Mejorana & $\begin{array}{l}\text { Tónico estomacal, sistema nervioso, antiespasmódico, } \\
\text { amenorrea. }\end{array}$ \\
\hline Manzanilla & $\begin{array}{l}\text { Se utiliza contra los dolores estomacales, dolores } \\
\text { musculares, dolores a las articulaciones, fiebre y para } \\
\text { disminuir la irritación y/o proteger las pieles sensibles. }\end{array}$ \\
\hline Menta & $\begin{array}{l}\text { Antiséptica y anti pruriginosa, bronquitis, indigestión, } \\
\text { reduce los síntomas de la migraña. }\end{array}$ \\
\hline Mejorana & $\begin{array}{l}\text { Dolores menstruales, cefaleas, afecciones faríngeas, } \\
\text { moderadamente sedante, inductor del sueño, } \\
\text { calorífero, mejora la circulación, algunas infecciones } \\
\text { fúngicas (como las aftas), acné. }\end{array}$ \\
\hline Naranja & $\begin{array}{l}\text { Antioxidante, fuente de vitamina } \mathrm{C} \text {, antidepresiva y anti } \\
\text { estrés, microbicida, ayuda a la absorción de hierro. }\end{array}$ \\
\hline $\begin{array}{l}\text { Patchouli o } \\
\text { Pachuli }\end{array}$ & $\begin{array}{l}\text { Anti-depresivo que también se usa para contrarrestar } \\
\text { los problemas de hongos, la caspa y los signos del } \\
\text { envejecimiento. }\end{array}$ \\
\hline
\end{tabular}

\begin{tabular}{|l|l|}
\hline Romero & $\begin{array}{l}\text { Estimula la memoria, la claridad mental, procesos } \\
\text { creativos, es un protector psíquico y un estimulante } \\
\text { físico. Aliviar dolores de las articulaciones, mejora la } \\
\text { cistitis, }\end{array}$ \\
\hline Rosa & $\begin{array}{l}\text { Sinusitis y afecciones faríngeas, congestión, edema } \\
\text { palpebral, hinchazón facial, algunos problemas } \\
\text { circulatorios capilar), } \\
\text { moderadamente sedante, inductor del sueño, tensión o } \\
\text { dolor premenstrual, antidepresivo, síntomas } \\
\text { menopaúsicos, disminución de la libido, anorexia } \\
\text { nerviosa. }\end{array}$ \\
\hline Sábila & $\begin{array}{l}\text { Acción digestiva, efecto depurativo, favorece la } \\
\text { regeneración de tejidos internos, elimina hongos y virus, } \\
\text { protege el sistema inmunitario, efecto antiinflamatorio, } \\
\text { anticancerígeno. }\end{array}$ \\
\hline Salvia & $\begin{array}{l}\text { Antiinflamatoria, reduce la flatulencia, dolores } \\
\text { menstruales. }\end{array}$ \\
\hline Sándalo & $\begin{array}{l}\text { Suaviza la piel seca y agrietada, mejorando la textura de } \\
\text { todo tipo de pieles. Calma la depresión, la ansiedad y los } \\
\text { sentimientos de pánico. Es euforizante. El aroma de } \\
\text { sándalo mejora la respiración y favorece la meditación y } \\
\text { la creatividad. Mejora la calidad del sueño. }\end{array}$ \\
\hline Vetiver & $\begin{array}{l}\text { Antiséptico de vías respiratorias y antitusivo. Es tónico y } \\
\text { energizante en el nivel físico, mental y emocional, } \\
\text { mejora la memoria. Es carminativo, antiséptico aun en } \\
\text { heridas abiertas. }\end{array}$ \\
\hline Ylang-Ylang & $\begin{array}{l}\text { Tranquilizflamatorio, antiséptico, cicatrizante, calmante. } \\
\text { Tomillo relajante muscular, cuidado del cabello. }\end{array}$ \\
\hline
\end{tabular}




\section{CAPÍTULO 4.}

\section{BIOTECNOLOGÍA Y BIOPROCESO}

Biotecnología es la integración de ciencias naturales y de ingeniería aplicada a microorganismos, células o sus componentes con el propósito de generar productos o servicios. Se puede hacer una distinción entre dos tipos de biotecnologías: tradicional y moderna.

La biotecnología tradicional es la que se ha usado por siglos para mejorar cultivo de plantas y cría de animales, así como también elaborar pan, queso, vino y cerveza. En ésta se utilizan los organismos sin ningún tipo de manipulación genética. Durante la segunda guerra mundial la industria farmacéutica da comienzo, con la Penicilina, a la manufactura de antibióticos a partir de la fermentación microbiana.

Por otro lado, la biotecnología moderna se basa en la manipulación genética "in vitro" de células o microorganismos con un propósito determinado. Esto es conocido como Ingeniería Genética o Tecnología del ADN recombinante (ADN-r). El organismo modificado se conoce como Organismo Transgénico u Organismo Genéticamente Modificado.

Por su parte el bioproceso ue es todo aquel manejo industrial que involucra la manipulación de organismos vivos o sus componentes celulares para proveer bienes o servicios

$\checkmark$ Bienes: (antibióticos, hormonas, fermentos, vacunas, ácidos orgánicos, amino ácidos, biocombustibles, biomasa, etc.) $\checkmark$ Servicios (biorremediación, biolixiviación, tratamiento de efluentes)

Un bioproceso involucra la transformación de un sustrato determinado en productos mediante microorganismos, cultivos de células animales o vegetales o por materiales derivados de estos como las enzimas, estos productos se obtienen o modifican mediante procesos que involucran cambios físicos o químicos de la materia. $\mathrm{El}$ transporte de materia y energía es fundamental para muchos procesos biológicos y ambientales.

El bioprocesado es una parte esencial de muchas industrias como de alimentos, químicas, farmacéuticas. La utilización de microorganismos para transformar materiales biológicos en la producción de alimentos fermentados tiene su origen en la antigüedad. Desde entonces el bioprocesado ha experimentado un gran desarrollo para una amplia gama de productos comerciales que abarcan desde materiales relativamente baratos, como el alcohol industrial y los disolventes orgánicos, hasta compuestos químicos especiales muy caros como antibióticos, proteínas terapéuticas y vacunas. Las enzimas utilizadas en las industrias y células vivas, como levaduras de pan y de la cerveza, son también productos comerciales de bioprocesamiento. (Dorán, 1998).

Un bioproceso está compuesto de tres etapas principales: 


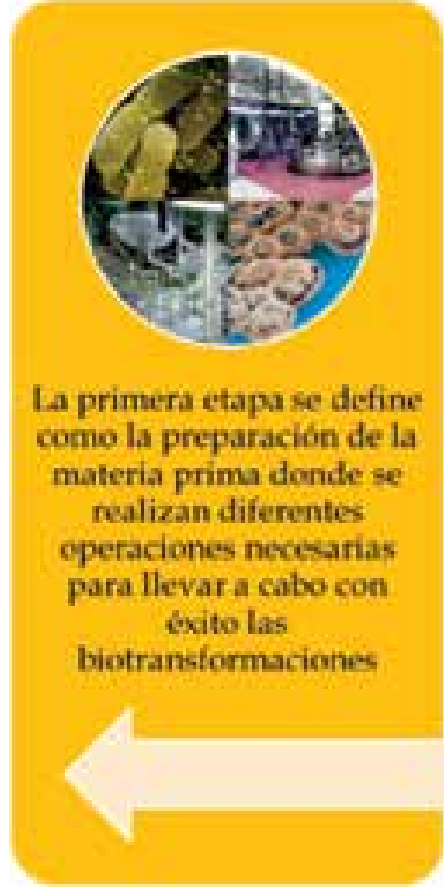

Figura 28: Etapas de un bioproceso

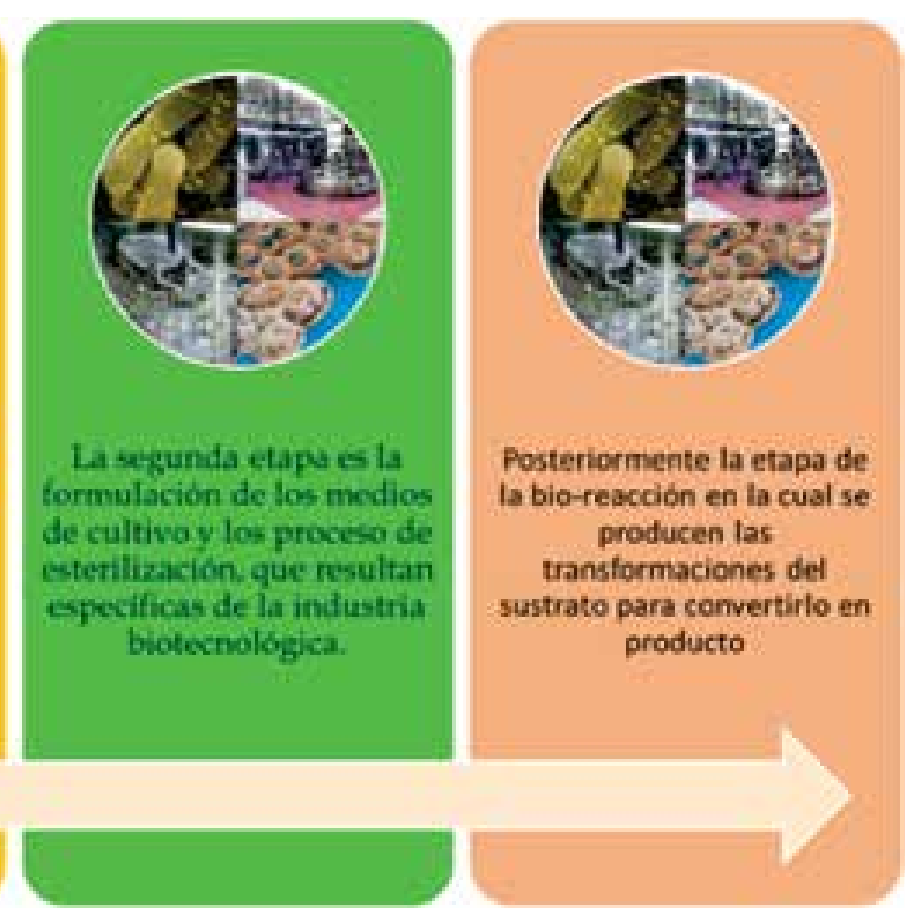

Fuente: Chalela, G. Diagrama propio, 2016

\section{2. ¿QUÉ ES UN BIORREACTOR?}

Comúnmente conocido como fermentador es un recipiente o sistema que mantiene un ambiente biológicamente activo. En algunos casos, un biorreactor es un recipiente en el que se lleva a cabo un proceso químico que involucra organismos o sustancias bioquímicamente activas derivadas de dichos organismos. Este proceso puede ser aeróbico (oxigénico) o anaeróbico (anoxigénico). Estos biorreactores son comúnmente cilíndricos, variando en tamaño desde algunos mililitros hasta metros cúbicos y son usualmente fabricados en acero inoxidable.
Un biorreactor puede ser también un dispositivo o sistema empleado para hacer crecer células o tejidos en operaciones de cultivo celular. Estos dispositivos se encuentran en desarrollo para su uso en ingeniería de tejidos. En términos generales, un biorreactor busca mantener ciertas condiciones ambientales propicias $(\mathrm{pH}$, temperatura, concentración de oxígeno, etcétera) al organismo o sustancia química que se cultiva.

En función de los flujos de entrada y salida, la operación de un biorreactor puede ser de tres modos distintos: 
$\checkmark$ Lote (batch)

$\checkmark$ Lote alimentado (fed-batch)

$\checkmark$ Continuo o quimiostato

Los biorreactores son los medios de cultivo optimizados empleados para la producción de sustancias a gran escala. Por ejemplo, las grandes cubas de vino o de cerveza, que pueden llegar a contener 30 mil litros de líquido se consideran biorreactores, puesto que otorgan a las levaduras fermentadoras su medio de crecimiento óptimo para la función deseada. Aunque en estos casos concretos, donde se pretende que un organismo realice una fermentación, los biorreactores se denominan también fermentadores. También es un biorreactor los recipientes artesanales de composteo, como tanques de pvc, cajas de madera, botellas, huecos en la tierra..etc

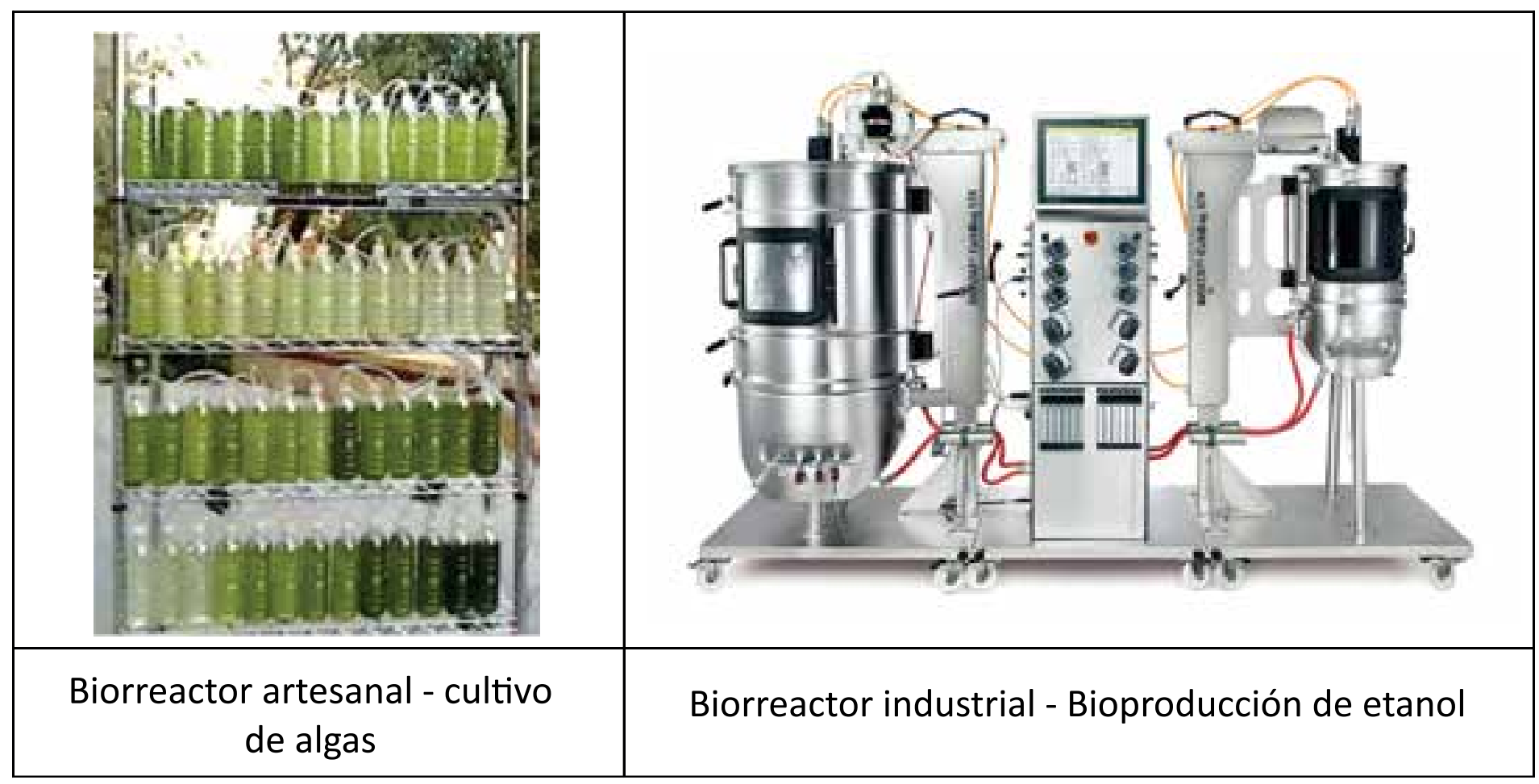

Figura 29. Tipos de reactores para proyectos artesanales e industriales

Fuente: Chalela, G. Cinbbya, Unab 


\section{BIOPREPARADOS}

Una de las principales limitaciones que deben superar, tanto los agricultores intra como periurbanos, es el manejo sostenible de plagas y enfermedades que causan pérdidas en los rendimientos y en la calidad de los productos, antes, durante y después de la cosecha. Por lo que un oportuno manejo de las plagas y enfermedades los beneficiará con una producción más eficiente, a menor costo, más segura para su salud y la de sus familias y respetuosa con el ambiente, los entornos urbanos y sus comunidades.
Los biopreparados son sustancias naturales que ayudan a repeler el ataque de plagas, hongos en los cultivos especialmente de hortalizas. Lo que se busca con estos biopreparados es minimizar el uso de productos químicos.

Consiste en preparaciones realizadas con productos naturales, para obtener compuestos químicos que son liberados por algunas plantas; se utilizan en control de plagas y enfermedades, para activar la vida del suelo, mejorar el crecimiento y desarrollo de las plantas.

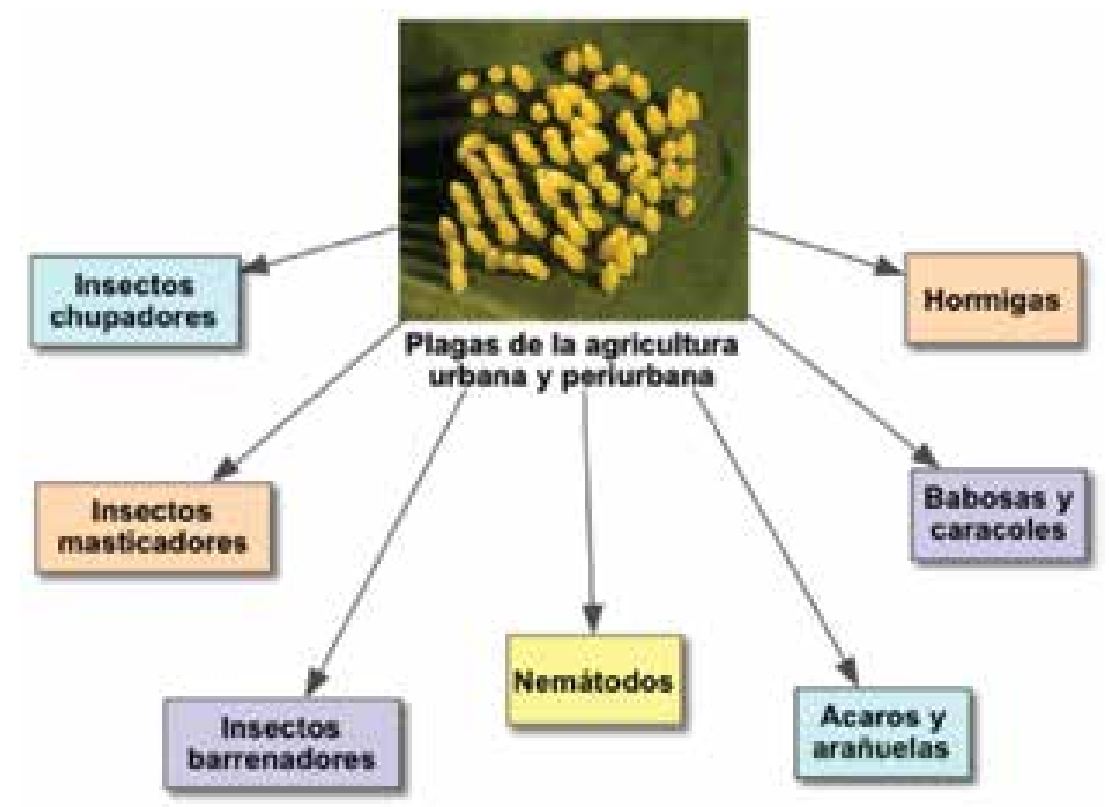

Figura 30. Principales plagas de la agricultura urbana y periurbana. 
Para corregir los desequilibrios que se manifiestan en ataques de plagas y enfermedades, la agricultura urbana sostenible utiliza productos elaborados a partir de materiales simples, sustancias o elementos presentes en la naturaleza (aunque en algunos casos pueden incorporar productos sintéticos) que protegen y/o mejoran los sistemas productivos en los que se aplican y que se denominan biopreparados.

Son sustancias y mezclas de origen vegetal, animal o mineral presentes en la naturaleza que tienen propiedades nutritivas para las plantas o repelentes y atrayentes de insectos para la prevención y control de plagas y/o enfermedades.

A lo largo de la historia, los biopreparados se han desarrollado a partir de la observación empírica de los procesos y efectos de control que realizan dichos productos. Por este motivo, la mayor parte de los biopreparados no tienen un autor definido y, en muchos casos, ni siquiera se conoce con precisión la ciudad o el país de origen. En los últimos años, estos proceso de observación que han realizado principalmente los agricultores, han comenzado a interesar a los investigadores, empresas e instituciones gubernamentales que han planteado su uso extensivo y comercial para la agricultura de pequeña y gran escala.

Pese a la facilidad en su preparación y su baja toxicidad, es importante mencionar que el manejo de los biopreparados requiere de cuidados para evitar la ingestión y el contacto con la piel (uso de guantes) de altas concentraciones de estos productos.

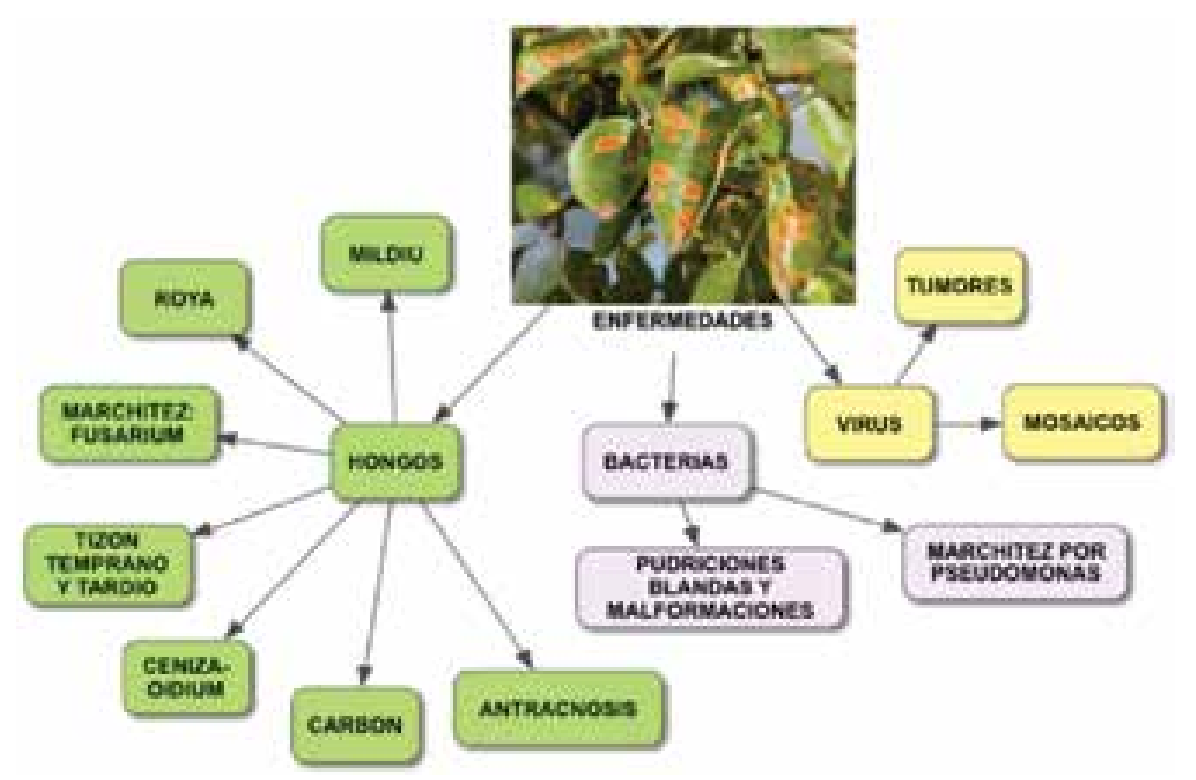

Figura 31. Principales causantes de enfermedades en las plantas.

Fuente: Chalela, G. Diagrama propio, 2016 


\section{ELABORACIÓN DE BIOPREPARADOS}

\section{- Caldo de ceniza: fertilizante, fungicida, bactericida}

Ingredientes: Dos kilos de ceniza. 4 litros de agua natural o de lluvia (nunca de acueducto). $1 / 2$ pasta de jabón azul o blanco.

Preparación: Se disuelve el jabón en el agua caliente, se espera unos minutos y se adicionan los dos kilos de ceniza a la solución jabonosa, se sigue revolviendo y se deja reposar, pudiéndose aplicar de inmediato

Uso: Se aplica por aspersión. Un litro de caldo por 10 litros de agua. Se utiliza en el control de la gota en tomate y papa. Regar foliarmente.

\section{- Extracto de ortiga: Fungicida}

Ingredientes: 1 kilo de ortiga verde, ojala antes de florecer. 2 litros de agua.

Preparación: Se macera la ortiga incluida la raíz, se procede a introducirla en un recipiente, de un galón se adiciona agua sin cloro; se tapa y se deja fermentar durante dos días. Al cabo de los cuales se filtran y se aplica por aspersión.

Uso: Se utiliza para controlar la gota en el tomate y en la papa. Se utiliza un litro de caldo para bomba de 20 litros. En el caso de que el problema sea agudo se disminuye la cantidad de agua a la mitad; es decir se utiliza un litro de caldo para bomba de 10 litros de agua.

Nota: se recomienda el uso de guantes para el manejo de la ortiga.

\section{- Caldo supermagro : Fertilizante}

Ingredientes: 100 litros de agua natural. 6 kilos de melaza. 30 kilos de estiércol vacuno fresco. 1 libra sulfato de hierro. 1 libra de sulfato de cobre. 1 libra de sulfato de magnesio. 1 libra de sulfato de zinc. 1 libra de sulfato de manganeso. 1 libra de bórax. 1 libra de sal mineralizada. 3.5 litros de leche o suero. 1 kilo de harina de pescado. (Opcional) 1 kilo de sal mineralizada. (Opcional)

Preparación: Disolver el estiércol con el agua, revolver bien hasta que se mezcle totalmente. En otro recipiente se disuelve muy bien 1 kilo de melaza en 3 litros de agua, se adiciona junto con un 1 kilo y medio de ceniza a la mezcla inicial. A partir del cuarto día se comienza a adicionar los micro elementos, uno por día, se puede iniciar con el sulfato de hierro, cada 5 días se va haciendo adición de cada micro elemento, acompañado de leche y melaza, lo que varía es el micro elemento. El proceso dura 45 días

Uso: se aplica un litro de caldo en 7 litros de agua.

\section{- Caldo bordelés: Fungicida}

Ingredientes: 10 litros de agua tibia, 100 gramos de cal viva,100 gramos de sulfato de cobre. Una mitad de una pasta de jabón azul o blanco.

Preparación: En un recipiente plástico se ponen 9 litros de agua tibia y se disuelven 100 gramos de cal viva; en otro recipiente plástico con un litro da agua tibia se disuelve los 100 gramos de sulfato de cobre, se revuelve y luego se vierte sobre la solución de cal, (nunca lo contrario) se agrega el jabón rayado. Se aplica de forma inmediata. Se aplica medio litro de caldo, por 3 litros y medio de agua.

Uso: sirve para controlar la gota de la papa y del tomate entre otros. 


\section{- Extracto ajo-aji: Insecticida}

Ingredientes: 1 libra de ajo criollo. 1 libra de ají picante y 4 litros de agua.

Preparación: Se maceran independientemente el ajo y el ají, seguidamente se llevan a recipientes plásticos o de vidrio separadamente; se dejan fermentar los contenidos durante 4 días, al fin del cual se filtran y se mezclan.

Uso: Sirve para el control de chupadores, pulgones, mosca blanca y ácaros. Se aplica foliarmente.

\section{BIOPREPARADOS DE USO DOMÉSTICO}

\section{Elaboración de champús naturales}

\section{- De Aloe Vera}

Ingredientes: Una taza de jabón neutro, 1/4 de taza de agua. 1 Cucharada de glicerina. 10 Gotas de esencia o aroma, según gusto. 1 Cucharada de aceite vegetal (opcional). $1 / 4$ de taza de Aloe Vera

Preparación: Se mezclan todos los ingredientes con ayuda de licuadora, cuando esté todo mezclado, se envasa y se refrigera.

Nota: Se debe tener en cuenta que como es un producto natural no se debe dejar a temperatura ambiente.

\section{Para Cabellos normales}

Ingredientes: 1 Puñado de salvia. 1 puñado de tomillo. 1 manojo de puntas de ortiga (frescas. 7 cucharadas de jabón neutro rallado. 1,5 litros de agua.
Preparación: En un recipiente se vierte el agua y se deja hervir, seguidamente se añaden las puntas de ortiga, el puñado de salvia y tomillo, se tapa y se deja hervir a fuego lento por 25 minutos. Seguidamente en otro recipiente se filtra y se agrega el jabón rallado, se revuelve con una cuchara de madera hasta que el jabón de diluya totalmente. Se retira del fuego y se deja enfriar.

\section{Elaboración de jabón casero en frío}

Ingredientes para 1 litro de aceite: Soda caustica 138 gr. Agua 380 ml. $482 \mathrm{~mL}$ de aceite de almendras o de oliva. Tintura de Benjuí. Oleato de limón o de otra planta

Preparación: En un lugar ventilado, con guantes, tapabocas y gafas, se inicia con la preparación de la soda la cual se recomienda trabajar con mucho cuidado debido a que es altamente toxica. La soda cáustica se agrega al agua muy lentamente ya que se produce calor y vapores; luego a esta mezcla se le agrega el aceite; de manera opcional se le agregan los aromas y colores deseados. Se realiza la mezcla de manera uniforme y en un solo sentido hasta que espese y llegue al punto adecuado para servir en los moldes.

\section{Crema de caléndula}

Ingredientes: 200 gr de extracto de oleoso de caléndula. $60-70$ gr de cera de abejas . $20 \mathrm{gr}$ de aceite esencial, de cualquier planta. Tarritos para envasar

Preparación: Se añade al recipiente la cera de abejas, luego se introduce en el microondas para que se derrita, se añaden los demás ingredientes, se mezclan y se envasa. Estas fórmulas se pueden utilizar con diferentes plantas, esencias y aromas, etc. 


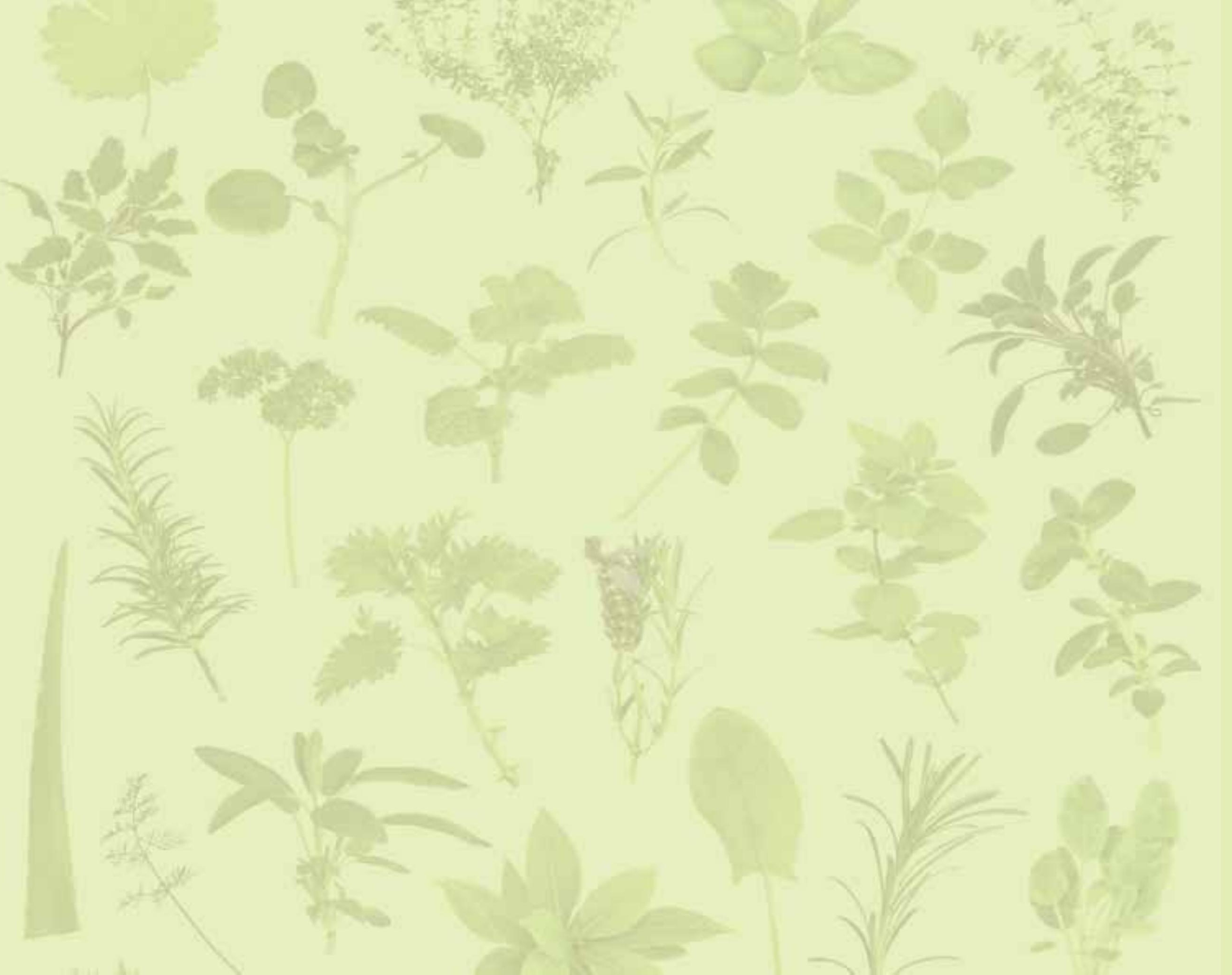




\section{CAPÍTULO 5.}

\section{GRANJA INTEGRAL AUTOSUFICIENTE}

Una granja integral autosostenible, es una extensión mínima de tierra, entre 3 a 5 hectáreas, en donde se integran la producción de abonos orgánicos (compost, humus), granos básicos (maíz, frijol, arveja), crianza de especies menores de animales (cabras, conejos, gallinas), mediante la tecnología buscar la mejor utilidad de todos los recursos existentes dentro y alrededor del centro agropecuario, para proveer no solo de alimento, sino que a través de la venta de sus excedentes obtener ingresos y bienestar para sus las personas que la habitan.

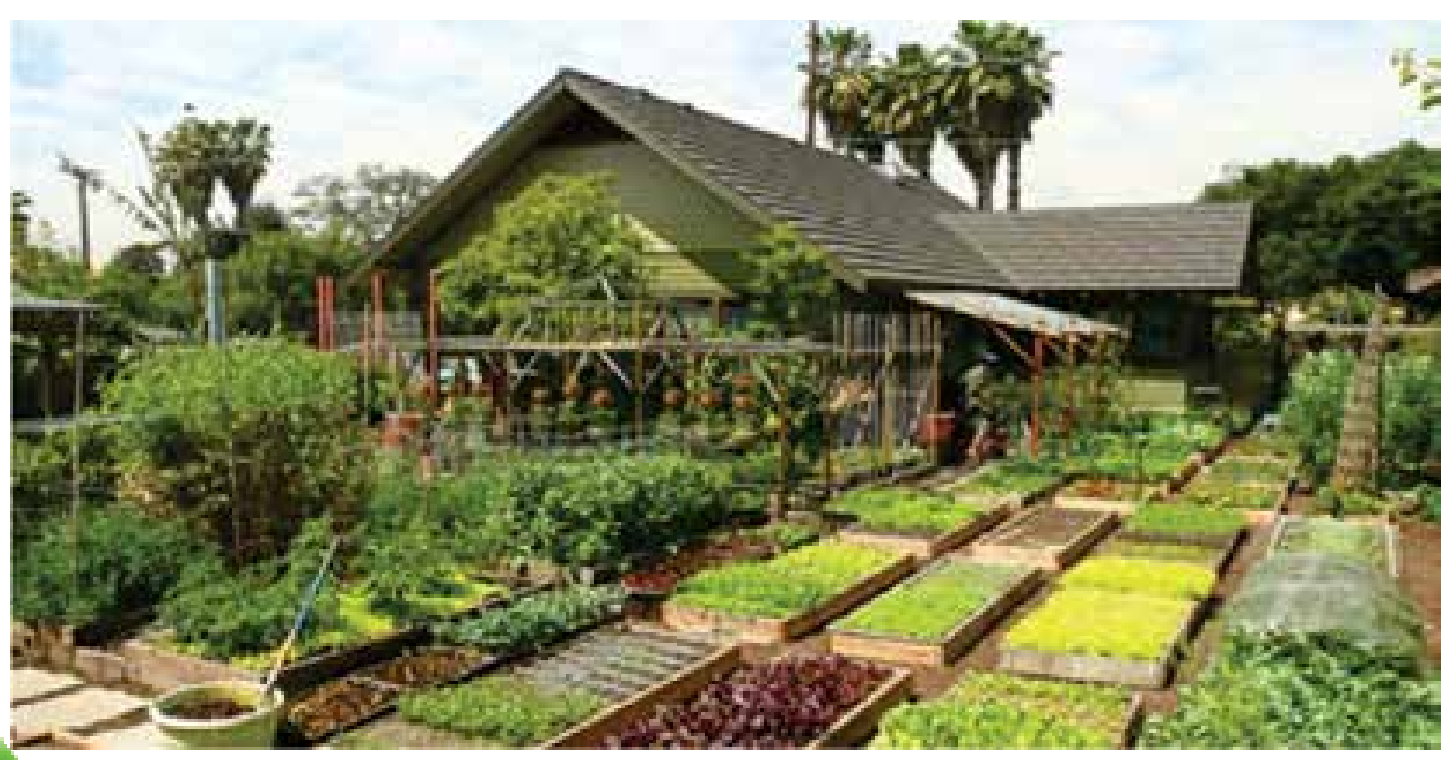

La granja integral autosuficiente nace por la necesidad de dejar la dependencia a los combustibles fósiles y fortalecer e impulsar a las familias campesinas para mantener la soberanía alimentaria. Básicamente se trata de educar a cada uno de sus integrantes para vivir en armonía con la naturaleza, preservando y disfrutando el medio que los rodea, evitando la tala de bosques, conservando los nacimientos de agua y propiciando el mejoramiento de las tierras y de los cultivos. Adicionalmente, estimula el uso de tecnologías apropiadas como energía solar y biodigestores (producción de gas metano) que contribuyen al bienestar de la familia campesina y facilita en corto plazo alcanzar los niveles de autosuficiencia y sostenibilidad deseados.

Las granjas autosuficientes se caracterizan por:

Figura 32. Granja integral autosuficiente. Subachoque. 


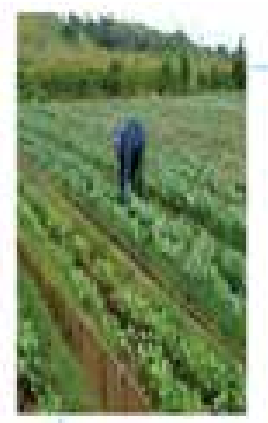

Promover una agricultura sana, sin uso de fertilizantes, plaguicidas, herbicidas y cualquier tipo de producto químico.

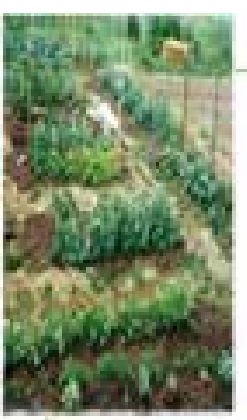

\section{No utilizar concentrados de alto costo para la alimentación animal.}

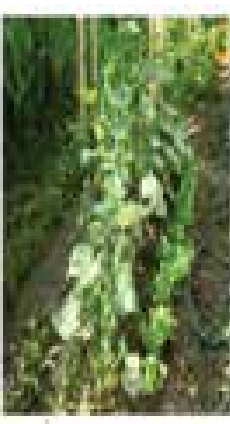

\section{Producir la mayor parte de los} alimentos requeridos por los animales que se tienen en la granja.

Figura 33. Características de una granja autosuficiente

Fuente: Chalela, G. Diagrama propio, 2016

\section{PERMACULTURA}

La permacultura es un sistema de diseño fundado en la ética y principios que se pueden usar para establecer, diseñar, coordinar y mejorar todos los esfuerzos hechos por individuos, hogares y comunidades que trabajan para un futuro sostenible.

Un hábitat diseñado según los principios de la permacultura se entiende como un sistema, en el cual se combinan la vida de los seres humanos de una manera respetuosa y beneficiosa con la de los animales y las plantas, para proveer las necesidades de todos de una forma adecuada.

En el diseño de estos sistemas se aplican ideas y conceptos integradores de la teoría de sistemas, biocibernetica (ciencia de la comunicación y el control en y entre los organismos vivos y su interacción con los sistemas mecánicos o electrónicos) ecología profunda. La atención no solo se dirige hacia los componentes individuales (=elementos), sino hacia las relaciones entre estos elementos y su uso óptimo para la creación de sistemas productivos.

Las ecoaldeas son aldeas ecológicas, pero la intuición no sirve para mucho más que para llegar hasta este punto, imaginar que son una especie de caseríos o pequeños pueblos en los que se lleva una vida armónica con el medio ambiente.

El concepto de ecoaldea implica tanto aspectos relacionados con las tecnologías renovables como una filosofía vital distinta a la imperante, que apuesta por un estilo de vida diferente, auténtico y respetuoso con el entorno.

Hablar de una ecoaldea es necesariamente hablar de permacultura. Si la ecoaldea es sinónimo de una forma de vida alternativa y sostenible, de una comunidad solidaria que busca la 
autosuficiencia energética y alimentaria, la permacultura tiene que ver con ecosistemas agrícolas y hábitats sostenibles, integrando desde la producción agrícola hasta el espacio de vida, el paisaje, el reciclaje, la reutilización, los métodos de obtención de energía...

En realidad, en ambos casos se busca trascender la sostenibilidad para alcancar un resultado positivo, de productividad y reducción de polución, buscando, por ejemplo, una huella de carbono negativa y un superávit en generación de energía o en agricultura.

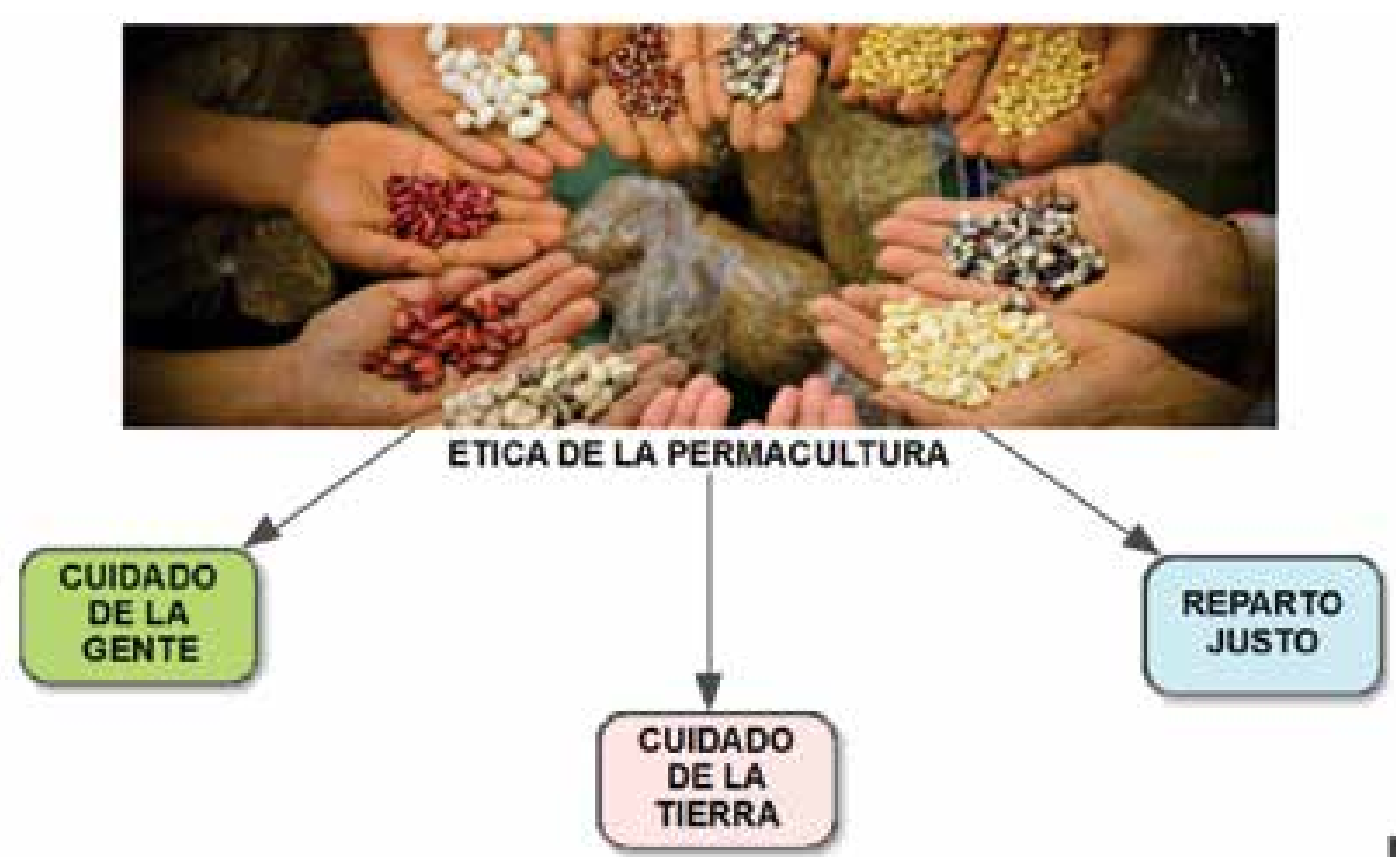

Figura 34.Etica de la permacultura

Fuente: Chalela, G. Diagrama propio, 2016

La Permacultura es entonces un término genérico para la aplicación de éticas y principios de diseño universales en planeación, desarrollo, mantenimiento, organización y la preservación de hábitat apto de sostenerse en el futuro.
La Permacultura también es una red y un movimiento internacional de practicantes, diseñadores y organizaciones, la gran mayoría de las cuales se han desarrollado y sostenido sin apoyo de corporaciones, instituciones o gobiernos.

Los ejes centrales de la permacultura son la producción de alimentos, abasto de energía, el diseño del paisaje y la organización de estructuras sociales. También integra energías renovables y la implementación de ciclos de materiales en el sentido de un uso sustentable de los recursos al nivel ecológico, económico y social. Desde sus inicios a finales de los años 70 , la permacultura se ha definido como una respuesta positiva a la crisis ambiental y social que estamos viviendo.

Posee un enfoque ecosistémico; un hábitat diseñado según los principios de la permacultura se entiende como un sistema, en el cual se combinan la vida de los seres humanos de una manera respetuosa y beneficiosa con la de los animales y las plantas, para proveer las necesidades de todos de una forma adecuada. En el diseño de estos sistemas se aplican ideas y conceptos integradores de la teoría de sistemas, biocibernetica y ecología profunda. La atención no solo se dirige hacia los componentes individuales, sino hacia las relaciones entre estos elementos y su uso óptimo para la creación de sistemas productivos.

La ecología profunda es un enfoque holistico hacia el mundo, que une pensamiento 
sentimiento, espiritualidad y acción - Trata sobre como trascender el individualismo de la cultura occidental para vernos a nosotros mismos como parte de la tierra, lo que nos lleva a una conexión más profunda con la vida, donde la ecología no es algo que pasa "alli afuera", sino algo de lo cual formamos parte.

La planeación, implementación y mantenimiento componen el proceso de diseño de la permacultura, el cual se enfoca tanto en una optimización sucesiva del sistema para las necesidades de ahora, como también en una futura productividad, abierta para ser desarrollada y refinada por las generaciones que vienen

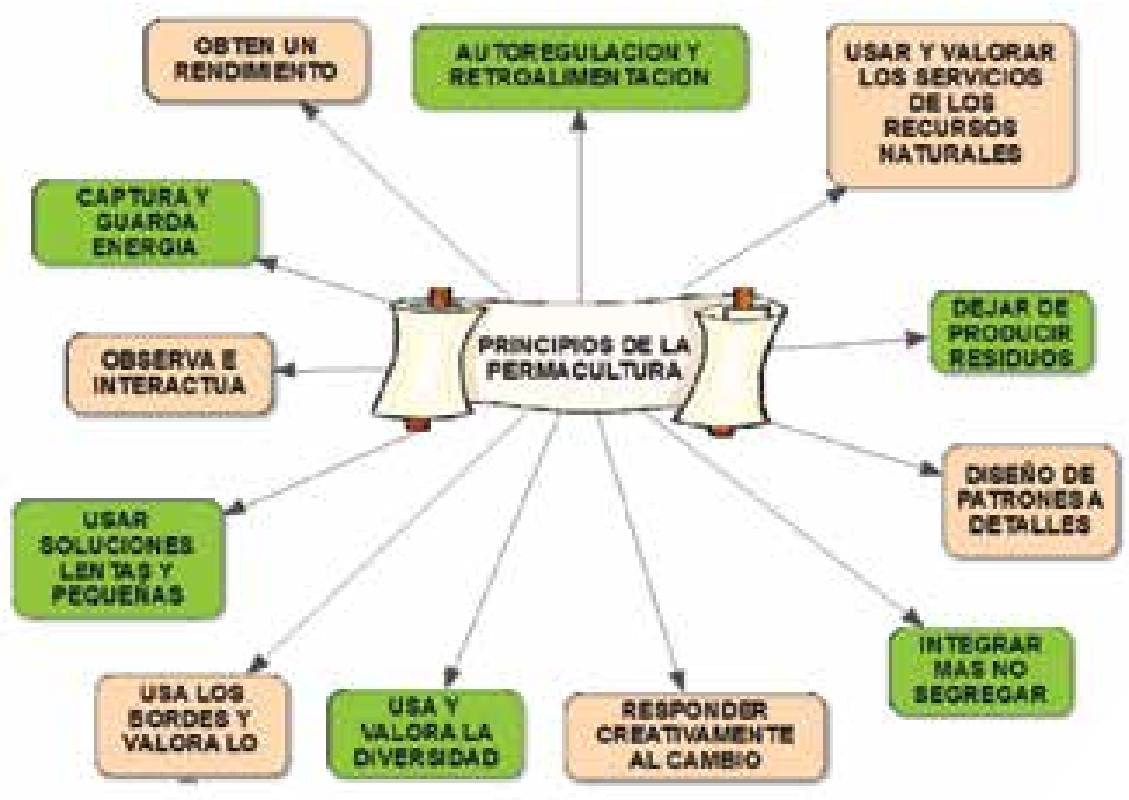

Figura 35. Principios de la permacultura.

Fuente: Chalela, G. Diagrama propio, 2016 


\section{CAPÍTULO 6.}

\section{ASOCIATIVIDAD}

El individuo como ser social, ha necesitado de los demás para satisfacer las necesidades básicas como son: alimentación, salud, vivienda, vestido etc.

La asociatividad, es tanto una facultad social de los individuos, como un medio de sumar esfuerzos y compartir ideas a través de la asociación de personas para dar respuestas colectivas.

Como instrumento de participación social se caracteriza por surgir del común acuerdo, en que un grupo humano en concordancia con las voluntades individuales que lo componen, considera tener intereses similares y un mismo objetivo a realizar, formando así una asociación en particular.

La asociatividad se caracteriza por ser un principio de convivencia voluntaria e igualitaria con respecto al poder. Además el objetivo de es mejor la gestión, la productividad y la competitividad en el sentido de globalización.

Como facultad social, los individuos humanos son seres sociales y a la vez selectivos, por lo que por un lado se encuentran en la necesidad de asociarse y por otro están en capacidad de elegir con quienes, por qué y de qué manera, por lo que se puede hablar de una necesidad social de afinidad selectiva.

La Asociatividad se rige por los siguientes parámetros:

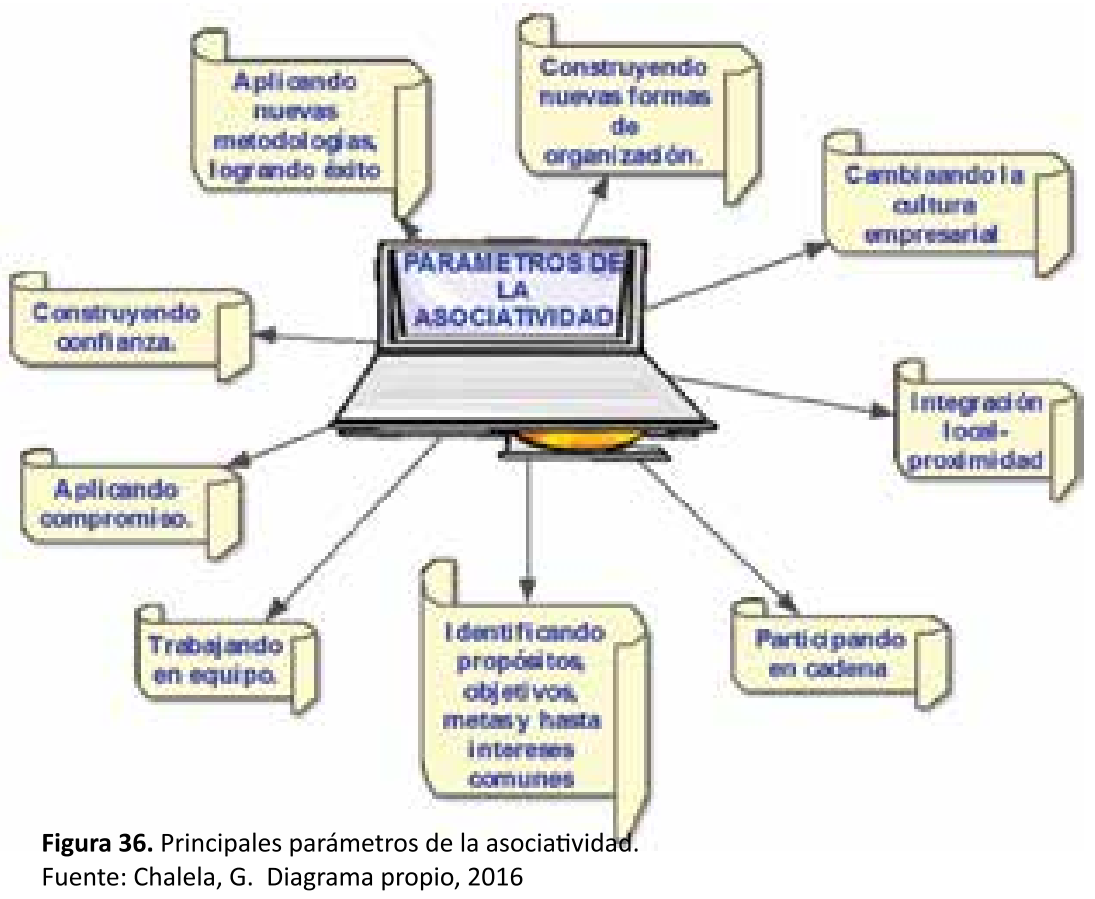

Si existe Asociatividad se puede:

- Minimizar debilidades y potenciar fortalezas.

- Disminuir barreras de entrada a ciertos mercados.

- Permitir la coordinación en las cadenas productivas. 
- Facilitar la creación de economías de escala.

- Reducir los costos de transacción en las etapas del proceso productivo.

- Propiciar un uso más eficiente de los factores de producción.

- Reducir los riesgos asociados a la volatilidad del mercado.

- Mejorar el acceso a los servicios financieros y a la información.

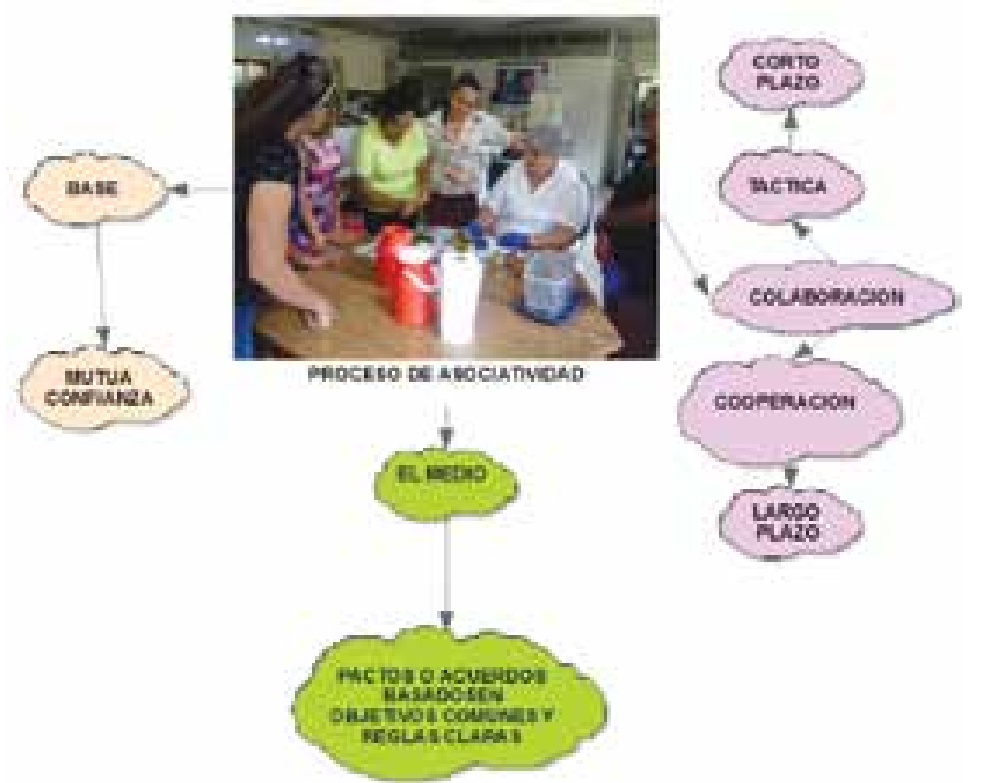

Figura 37. Proceso de asociatividad.

Fuente: Chalela, G. Diagrama propio, 2016

\section{TIPOS DE ASOCIATIVIDAD}

Redes de Cooperación: Conjunto de empresas que comparten información, procesos o conglomeran ofertas, sin renunciar a funcionar de manera independiente. No existe una relación de subordinación. Mantienen diversos vínculos cooperativos para realizar acciones conjuntas coordinadas.

Articulación Comercial: Relación sostenida entre empresas ofertantes y demandantes la cual puede ser mediada o animada por un agente intermediario, bróker o gestor de negocios.

Alianza en Clusters. (Colaboración para competir). Son similares a las cadenas de valor, pero los actores están concentrados geográficamente y están interconectados en una actividad productiva particular. Comprende no sólo empresas sino también instituciones que proveen servicios de soporte empresarial.

Una agrupación de empresas e instituciones relacionadas entre sí, pertenecientes a un mismo sector o segmento de mercado, que se encuentran próximas geográficamente y que colaboran para ser más competitivos

Joint Venture: Joint significa común o conjunto, mientras que Venture una aventura, un proyecto, una empresa; ello implica que hay esfuerzos y riesgos por delante, pero también la posibilidad de un resultado positivo, una utilidad, un beneficio.

Una Joint Venture operacional es una sociedad a través de la cual dos o más firmas crean una entidad jurídica nueva y separada para llevar a cabo una actividad económica productiva o de prestación de servicios, en la cual cada parte toma un activo papel en el proceso de toma de decisiones.

Consorcios: es aquel por virtud del cual dos o más personas se asocian para participar en forma activa y directa en un determinado negocio o empresa con el propósito de obtener un beneficio económico. Los Consorcios se pueden formalizar legalmente sin que las empresas pierdan su personería jurídica pero con una gerencia común. 
Alianza en Cadenas Productivas: En base a acuerdos entre actores que cubren una serie de etapas y operaciones de producción, transformación, distribución y comercialización de un producto o línea de productos (bienes o servicios). Implica división de trabajo en la que cada agente o conjunto de agentes realiza etapas distintas del proceso productivo.

\section{¿CÓMO ASOCIARSE?}

- Encontrar pares con objetivos comunes.

- Generar alianzas para para lograr metas comunes.

- Cooperar y participar en la alianza.

- Aplicar principios de transparencia en la alianza.

- Vivenciar los principios solidarios.

\section{LOGROS DE LA ASOCIATIVIDAD EN UN MUNDO GLOBALIZADO}

- Acceso a nuevos mercados, nacionales e internacionales.

- Intercambio tecnológico y empresarial que mejorará la productividad.

- Mayor capacidad exportadora (incremento del volumen de la productividad)

- Reducción de costos en la producción.

\section{IMPORTANCIA DE TRABAJAR EN EQUIPO}

Trabajar en equipo:

1. Construye confianza. La confianza es el elemento principal del trabajo en equipo. Impulsa un ambiente donde todos los

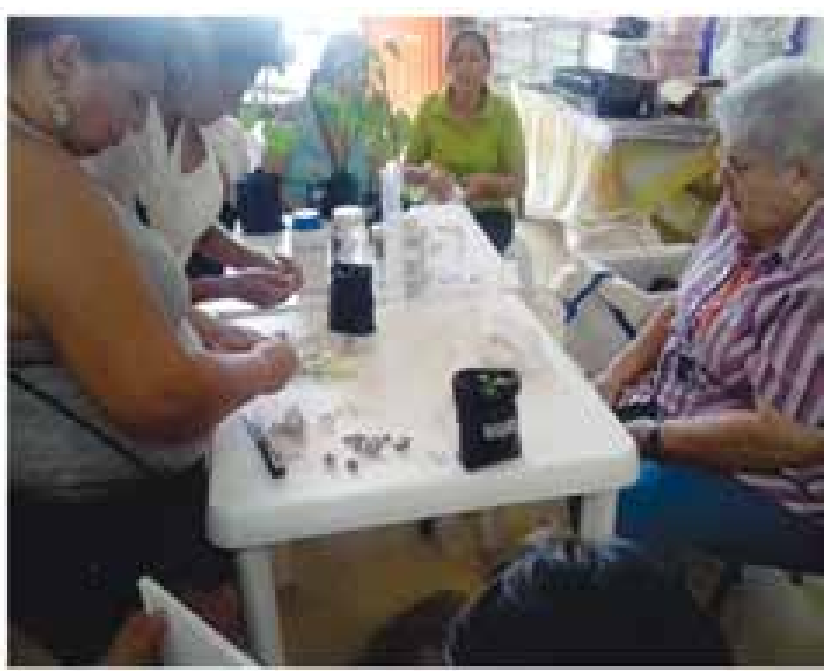

Figura 38. Aprendizaje para la asociación. Mujeres cabeza de hogar de Lebrija Santander, bajo la asesoría de Unab Ambiental.

Fuente: Archivo Unab Ambiental.

participantes conozcan las habilidades de los demás, entiendan sus roles y sepan cómo ayudarse mutuamente

2. Establece objetivos comunes. Para que tus empleados trabajen en equipo deben perseguir las mismas metas. Por ello, es importante que comuniques la misión de la empresa de manera uniforme y que definas cómo cada miembro y departamento puede contribuir a cumplirla

3. Crea un sentido de pertenencia. Los seres humanos necesitamos sentirnos parte de algo; por eso, el factor más poderoso en la creación de equipos es el desarrollo de una identidad común. Define qué identifica a tus equipos, fija valores y haz que cada miembro esté consciente de su impacto en el equipo

4. Involucra a la gente en las decisiones. Nada afecta más un trabajo en equipo que el hecho de que las decisiones sean tomadas por un 


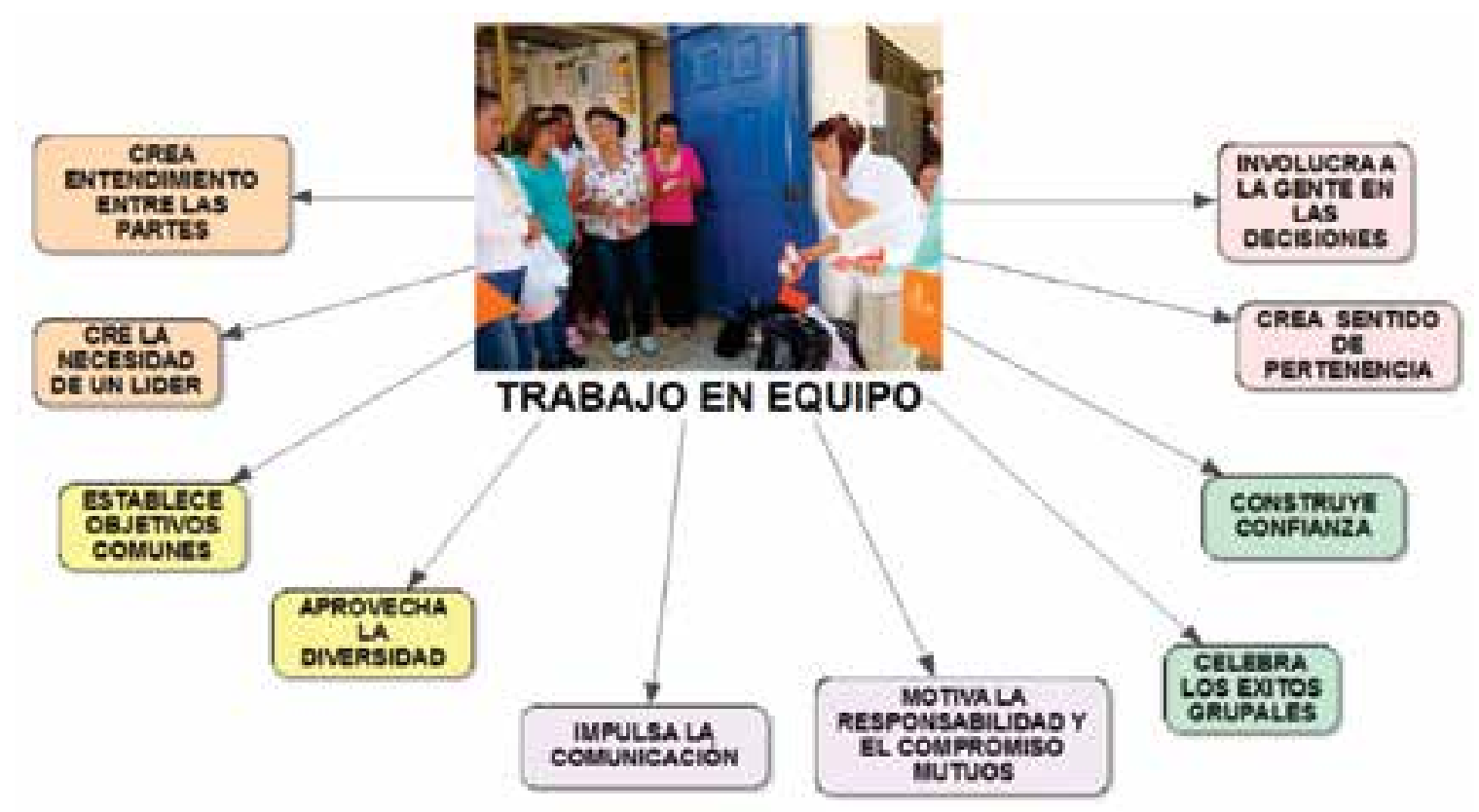

Figura 39. Ventajas de trabajar en equipo.

Fuente: Chalela, G. Diagrama propio, 2016

líder autócrata. Para evitarlo, impulsa la generación de ideas, abre tu mente y motiva a cada empleado a compartir su opinión. Si tienes esta retroalimentación, será más fácil implementar cualquier cambio o estrategia.

5. Hace que haya un entendimiento entre las partes. Es muy fácil criticar o subestimar el trabajo de los demás cuando uno no lo conoce o no lo ha ejecutado. Para crear empatía entre tus trabajadores, realiza ejercicios de rotación entre áreas. Así cada miembro sabrá en qué consiste la labor del otro y cómo puede contribuir a hacerlo mejor.

6. Motiva la responsabilidad y el compromiso mutuos. Cuando una persona es parte de un equipo, sabe que los logros o fracasos son responsabilidad de todos y cada uno de los miembros. No fomentes la mentalidad de "éste no es mi problema"; haz que los problemas y los aciertos sean compartidos

7. Impulsa la comunicación. La única manera de que todos los miembros trabajen como una orquesta es que existan los canales de comunicación adecuados. Los verdaderos equipos se escuchan y retroalimentan. Están dispuestos a cambiar de opinión y a crear estrategias en conjunto.

8. Aprovecha la diversidad. Un equipo de trabajo homogéneo puede operar con eficiencia pero sin mucha innovación. Al momento de crear tus equipos procura que haya personalidades e intereses distintos, pero que se compartan valores y un compromiso con la empresa 
9. Celebra los éxitos grupales. Aunque es importante también reconocer el trabajo individual, es clave que las recompensas se den por resultados en equipo. Cuando algo sale bien, reúne a todos los implicados y agradéceles su trabajo. Procura destacar el papel de cada uno, pero celebrar el resultado grupal

10. Crea la necesidad de un líder. Todo equipo de trabajo necesita un líder que guíe y reúna los esfuerzos individuales. No te "laves las manos" y sé parte del equipo. Como líder tendrás que llegar a consensos y tomar decisiones, con base en las ideas y opiniones de tu equipo.

\section{COOPERATIVAS}

Una cooperativa es una asociación autónoma de personas unidas voluntariamente para satisfacer sus necesidades y aspiraciones económicas, sociales y culturales comunes, a través de una empresa de propiedad conjunta y democráticamente controlada.

Consultada la Dra Tatiana Suárez, abogada financiera, sobre las mejores opciones de asociatividad para el grupo que Unab Ambiental capacita, conseja que la mejor forma de asociarse es por medio de cooperativas.

Las cooperativas, en sus distintas formas, promueven la máxima participación posible de todas las personas en el desarrollo económico y social, incluidas las mujeres, los jóvenes, las personas de edad, las personas con discapacidad y las personas indígenas, son cada vez más un factor clave del desarrollo económico y social y

En Colombia las cooperativas se rigen por la ley 79 del 23 de diciembre 1988, reglamentada por el decreto nacional 468 de 1990.

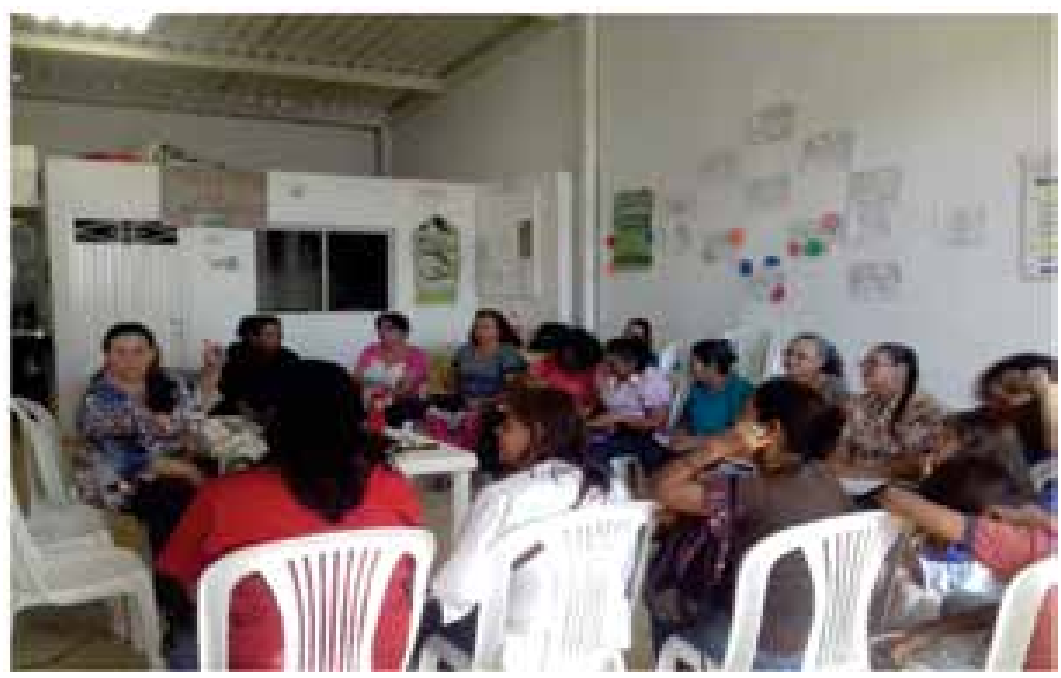

Figura 40. Capacitación en cooperativismo de mujeres cabeza de hogar. Unab Ambiental en Lebrija, Santander.

\section{CARACTERÍSTICAS DE LAS COOPERATIVAS}

- Que tanto el ingreso de los asociados como su retiro sean voluntarios.

- Que el número de asociados sea variable e ilimitado.

- Que funcione de conformidad con el principio de la participación democrática.

- Que realice de manera permanente actividades de educación cooperativa.

- Que se integre económica y socialmente al sector cooperativo.

- Que garantice la igualdad de derechos y obligaciones de sus asociados sin consideración a sus aportes. 
- Que su patrimonio sea variable e ilimitado; no obstante, los estatutos establecerán un monto mínimos de aportes sociales no reducibles durante la existencia de la cooperativa.

- Que tenga una duración indefinida en los estatutos, y.

- Que se promueva la integración con otras organizaciones de carácter popular que tengan por fin promover el desarrollo integral del hombre.

\section{TIPOS DE COOPERATIVAS}

Cooperativas Especializadas: Las que se organizan para atender una necesidad específica, correspondiente a una sola rama de actividad económica, social o cultural.

Cooperativas Multiactivas: las que se organizan para atender varias necesidades, mediante concurrencias de servicios en una sola entidad jurídica. Los servicios deben ser organizados en secciones independientes

Cooperativas Integrales: aquellas que en desarrollo de su objeto social, realicen dos o más actividades conexas y complementarias entre si, de producción, distribución, consumo y prestación de servicios.

Cooperativas de trabajo asociado: Su originalidad reside en el hecho de que los trabajadores son socios mayoritarios de la empresa de la que poseen al menos un $51 \%$ del capital. Al ser socios mayoritarios de la cooperativa, los trabajadores deciden juntos las grandes líneas de su empresa y designan sus líderes (gerentes, consejo de administración, etc.)

Pre-cooperativas: empresas asociativas sin ánimo de lucro de duración limitada.

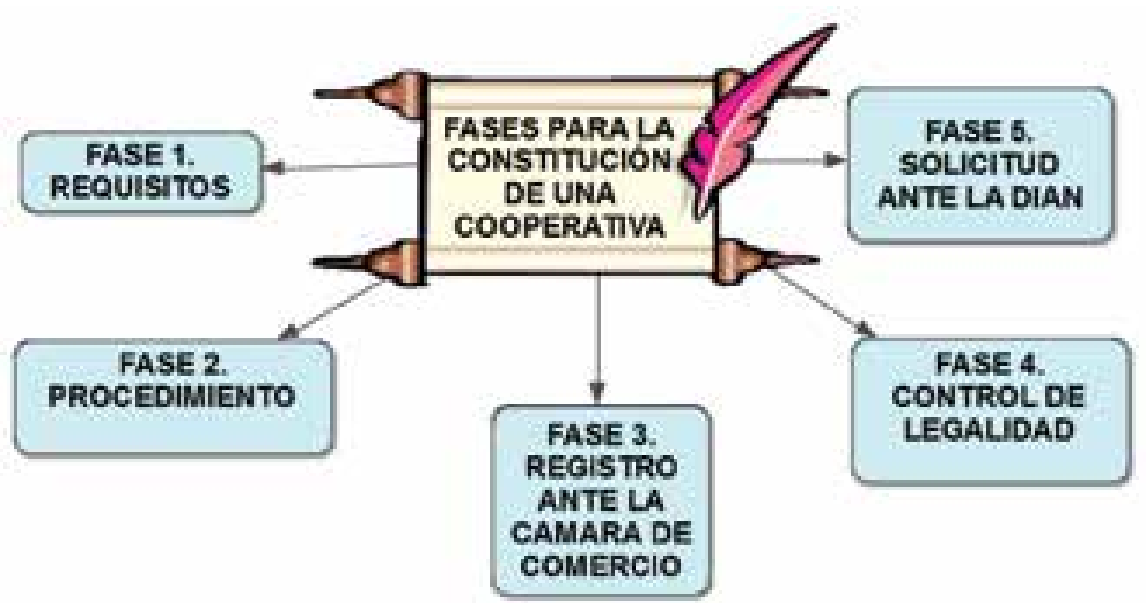

Figura 41. Fases para constituir una cooperativa. Fuente: Chalela, G. Diagrama propio, 2016

\section{FASES PARA LA CONSTITUCIÓN \\ DE UNA COOPERATIVA}

\section{FASE 1: REQUISITOS}

- Contar con un mínimo de 20 personas.

- Nombrar un comité organizador.

- Todos los socios tienen un curso básico en economía solidaria de 20 horas.

- Elaborar estatutos.

- Determinar el tipo de cooperativa a constituir.

FASE II: PROCEDIMIENTO

- Convocar a la Asamblea de constitución. 
- Nombrar al presidente y secretario de la Asamblea.

- Realizar la asamblea, y en ella se elige al Consejo, la Junta de Vigilancia, el Revisor Fiscal, y los comités.

- Definir el nombre la cooperativa y los aportes sociales.

- Aprobar los estatutos.

- El Consejo de Administración nombra representante legal o Gerente.

- Elaborar el acta de constitución con la firma del presidente, secretario de la Asamblea y de todos los asociados fundadores.

- La junta de Vigilancia estará integrada por máximo 3 asociados hábiles con sus respectivos suplentes, su periodo y causales de remoción serán fijados en los estatutos.

\section{FASE III: REGISTRO ANTE CÁMARA DE COMERCIO}

Para obtener el registro de la Empresa sin ánimo de lucro y registrar la Corporación ante la Cámara de Comercio, es necesario contar con los siguientes documentos:

- Actas de la Asamblea de constitución, aportes y aceptación de cargos suscrito por Presidente y secretario de la Asamblea y de todos los que conforman la cooperativa.

- Copia de los estatutos firmados por los asociados, el presidente y secretario de la asamblea.

- Diligenciar el formulario del registro único empresarial de la Cámara de Comercio.

- Diligenciar el formulario adicional de registro con otras entidades.
- Diligenciar el formulario pre-RUT que se puede encontrar en la pag de internet de la página de la DIAN, o reclamarlo en físico en las oficinas de dicha entidad.

- Pueden asociarse, tanto personas jurídicas de derecho privado y del sector cooperativo, sin ánimo de lucro, como personas naturales mayores de 15 años.

\section{FASE IV: CONTROL DE LEGALIDAD}

El control de legalidad se tramita para las cooperativas de ahorro y crédito, multiactivas e integrales ante la superintendencia de la economía solidaria, Supersolidaria y las demás de acuerdo a su especialidad por actividad económica.

- Petición firmada por el representante legal y presidente de la junta de vigilancia en el formato de trámites.

- Original del acta de la asamblea de constitución y estatutos firmados por presidente y secretario de la asamblea.

- Certificado general del curso básico de veinte horas, dictado por una organización acreditada.

- Constancia de pagos de por lo menos el $25 \%$ de los aportes iniciales suscritos por los asociados fundadores.

- Certificado de antecedentes disciplinarios de Revisor Fiscal.

- Certificado de existencia y representación legal expedido por Cámara de Comercio.

- Certificación del representante legal en la cual conste que el revisor fiscal no es asociado. 


\section{FASE V: SOLICITUD ANTE LA DIAN}

- En la DIAN el representante legal debe solicitar el Registro Único Tributario RUT, al igual que la autorización de facturación. Para este trámite se debe llevar el certificado de existencia y representación legal expedido por Cámara de Comercio.

- Es importante tener en cuenta que los asociados deben ser personas con valores solidarios como: honestidad, responsabilidad, solidaridad, transparencia, ayuda mutua, igualdad, entre otros. 


\section{GLOSARIO}

\section{Abiosis}

Sin vida. Preferentemente se aplica a los animales que tienen la facultad de permanecer en estado de vida latente cuando las condiciones del medio no son las adecuadas.

\section{Agenda 21}

Programa para desarrollar la sostenibilidad a nivel planetario, aprobado por 173 gobiernos en la Conferencia de las Naciones Unidas sobre Medio Ambiente y Desarrollo celebrada en Río de Janeiro en 1992. Abarca aspectos económicos, sociales y culturales, así como relativos a la protección del Medio Ambiente.

\section{Agente cancerígeno}

Que provoca cáncer. La mayoría de los cancerígenos son también mutagénicos y muchos teratógenos.

\section{Agricultura sostenible}

Sistema de producción agropecuaria que permite obtener producciones estables de forma económicamente viable y socialmente aceptable, en armonía con el medio ambiente y sin comprometer las potencialidades presentes y futuras del recurso suelo.

\section{Agroecología}

Ciencia que brinda un manejo del agroecosistema, desarrollando cultivos sanos, fuertes y resistentes al ataque de plagas y enfermedades, protegiendo el medio ambiente y la salud del ser humano.

\section{Ambiente}

Conjunto constituido por los agentes físicos, químicos, biológicos, visuales y sociales que constituyen el escenario donde transcurre la existencia del ser humano.

\section{Bacteria}

Microorganismo unicelular procarionte, cuyas diversas especies causan las fermentaciones, enfermedades o putrefacción en los seres vivos o en las materias orgánicas.

\section{Biodegradable}

Capaz de ser asimilado (descompuesto y metabolizado) por el ecosistema.

\section{Biodiversidad}

Variabilidad de los organismos vivos en cualquier ecosistema, dentro de cada especie, entre las especies y los complejos ecológicos que forman parte. 


\section{Biomolécula}

Las biomoléculas son las moléculas constituyentes de los seres vivos. Los cuatro bioelementos más abundantes en los seres vivos son el carbono, hidrógeno, oxígeno y nitrógeno, representando alrededor del $99 \%$ de la masa de la mayoría de las células.

\section{Biotecnología}

Aplicación de la técnica correspondiente en el control de los seres vivos con objeto de hacerlos más valiosos para el ser humano.

La biotecnología es un área multidisciplinaria, que emplea la biología, química y procesos, con gran uso en agricultura, farmacia, ciencia de los alimentos, ciencias forestales y medicina. Probablemente el primero que usó este término fue el ingeniero húngaro Karl Ereky, en 1919. La biotecnología se refiere a toda aplicación tecnológica que utilice sistemas biológicos y organismos vivos o sus derivados para la creación o modificación de productos o procesos para usos específicos (Convention on Biological Diversity, Article 2. Use of Terms, United Nations. 1992).

\section{Botánica}

Es una rama de la biología y es la ciencia que se ocupa del estudio de los vegetales, bajo todos sus aspectos, lo cual incluye su descripción, clasificación, distribución, identificación y el estudio de su reproducción, fisiología, morfología, relaciones recíprocas, relaciones con los otros seres vivos y efectos provocados sobre el medio en el que se encuentran.

\section{Calidad ambiental}

Atributos medibles de un producto o proceso que en conjunto manifiestan su salud e integridad ecológica.

\section{Cambio Climático}

Modificación del régimen de temperaturas, precipitación y nubosidad respecto al historial climático, a una escala global o regional, debido tanto a causas naturales como antropogénicas (causadas por el hombre).

\section{Capacidad de uso del suelo}

Apreciación de la aptitud actual de un suelo y su potencial de ser modificado ante la presentación de limitantes.

\section{Compost}

Es una técnica que imita a la naturaleza para trasformar -de forma más acelerada- todo tipo de restos orgánicos, en lo que se denomina compost o mantillo, que tras su aplicación en la superficie de nuestra tierra se ira asociando al humus, que es la esencia del buen vivir de un suelo saludable, fértil y equilibrado en la naturaleza.

\section{Comunidad}

Conjunto de seres vivos que pueblan un territorio determinado, caracterizado por las interrelaciones que estos organismos tienen entre síy con su entorno.

\section{Daño ambiental}

Es el efecto causado al medio ambiente o a cualquiera de sus componentes naturales o culturales.

\section{Degradación}

Descomposición de una sustancia por rotura de los enlaces que unen los elementos químicos que la forman. Puede producirse por la acción del oxígeno, la luz, el calor y ciertos microorganismos. 


\section{Desarrollo sostenible}

Desarrollo que satisface las necesidades de las actuales generaciones sin poner en peligro las posibilidades de las futuras.

\section{Disposición final}

Toda operación de eliminación de residuos peligrosos que implique la incorporación de los mismos a cuerpos receptores, previo tratamiento.

\section{Diversidad biológica}

Variedad de especies (vegetales y animales); cuanto mayor sea más alta es la calidad del ecosistema.

\section{Ecodesarrollo}

Estilo particular de desarrollo que permite alcanzar la plena satisfacción de las necesidades del hombre a través de un desarrollo económico y social continuo en armonía con el manejo racional del ambiente.

\section{Ecoeficencia}

Gestionar simultánea y correctamente el costo, calidad y rendimiento con la conservación del medio ambiente y los recursos naturales.

\section{Ecosistema}

Es un conjunto de entidades interaccionantes agrupadas en dos clases: los factores abióticos que conforman el biotopo, y las especies biológicas presentes que constituyen la biocenosis o comunidad.

\section{Educación Ambiental}

Educación dirigida a individuos y grupos, con el fin de aumentar el conocimiento sobre el medio ambiente y llegar finalmente a cambios de conducta.

\section{Efecto invernadero}

Se aplica este nombre al calentamiento que puede causarse al aire atmosférico por la entrada de radiación solar cuando simultáneamente se inhibe la radiación saliente como consecuencia de las concentraciones crecientes de gases como $\mathrm{CO} 2$ (que se libera en los procesos de combustión de combustibles fósiles), metano y algunos fluorocarbonados, provenientes entre otros de pulverizadores y neveras.

\section{Endémico}

Propio o natural de un determinado lugar o región.

\section{Equilibrio Ecológico}

En un ecosistema, cuando las entradas y salidas de materia y energía están equilibradas.

\section{Extinción}

Desaparición de un organismo viviente con entidad propia, como puede ser una especie, ecotipo, variedad, etc.

\section{Fertilización}

Abastecer y suministrar los elementos inorgánicos u orgánicos al suelo para que la planta los absorba

\section{Fijación de Nitrógeno}

Proceso por el cual las bacterias que fijan el nitrógeno y que viven en asociaciones mutualistas con plantas convierten el nitrógeno 
atmosférico en compuestos de nitrógeno que las plantas pueden utilizar directamente.

\section{FONAM (Fondo Nacional para el Medio Ambiente Mundial)}

El Fondo nacional para el Medio Ambiente Mundial es un mecanismo de cooperación internacional creado con el propósito de ofrecer recursos en términos preferenciales y donaciones que permitan cubrir los costos para alcanzar beneficios medioambientales de carácter global en las áreas de Diversidad Biológica. Cambio Climático, Aguas Internacionales y Agotamiento de la Capa de Ozono.

\section{Fotosíntesis}

Proceso químico que consiste en la producción de biomasa por las plantas verdes, aprovechando la luz solar, agua, bióxido de carbono y sales.

\section{Gajos o esquejes}

Son los tallos de brotes nuevos y aún tiernos. Es el caso del ajenjo, albahaca, estragón, lavanda, orégano y salvia.

\section{Gases, Efecto Invernadero}

Conjunto de gases que liberados a la atmósfera provocan el calentamiento global del Planeta, lo que se conoce como efecto invernadero.

\section{Gestión Ambiental}

Medidas adoptadas por una empresa o cualquier entidad, encaminadas a disminuir la influencia negativa sobre el medio ambiente de sus actividades.

\section{Grupos Taxonómicos}

Categorías pertenecientes a la clasificación biológica: como orden, familia, género o especie. Bienes usados cuyo reprocesamiento no provocan contaminación, productos verdes.

\section{Hábitat}

Conjunto de condiciones ambientales en las que vive una biocenosis, una especie o un individuo.

\section{Humus}

Materia orgánica originada de la degradación de la materia viva, principalmente la vegetal; se caracteriza por su gran estabilidad y mineralización lenta.

\section{Impacto Ambiental}

El impacto ambiental es la alteración del medio ambiente, provocada directa o indirectamente por un proyecto o actividad en un área determinada, en términos simples el impacto ambiental es la modificación del ambiente ocasionada por la acción del hombre o de la naturaleza. Los proyectos o actividades susceptibles de causar impacto ambiental, en cualquiera de sus fases, que deberán someterse al Sistema de Evaluación de Impacto Ambiental.

In Situ

En latín, en el lugar. Dícese de las acciones que se llevan adelante en el lugar de interés.

Indicadores Ambientales

Variables que señalan la presencia o condición de un fenómeno que no puede medirse directamente y afecta al medio ambiente. 
Indicadores Biológicos

Se conoce así a los organismos vegetales o animales, utilizados para determinar estados de polución o de contaminación.

\section{Inhibición}

Efecto de frenado o parada de una reacción o proceso, ya sea química o bioquímica, por la acción de algún agente externo.

\section{Investigación Aplicada}

Trabajos destinados a adquirir conocimientos para su aplicación práctica en la producción y/o comercialización.

\section{Lixiviado}

Agua contaminada que gotea de un material de desecho. El lixiviado de vertederos está casi siempre gravemente contaminado por materia orgánica y metales pesados.

\section{Lluvia Ácida}

Lluvia que contiene ácidos disueltos y que por tanto supone una acidificación del medio ambiente. Las sustancias más importantes causantes de lluvia ácida pueden recorrer miles de kilómetros antes de precipitarse.

\section{Materia de Cobertura}

Material que es apto para el cubrimiento de las distintas capas de residuos en un vertedero a fin de evitar y prevenir el vuelo de plásticos y papeles, insectos, roedores, incendios, molestias visuales, polvo, mal olor y suciedad.

\section{Materia Orgánica}

Sustancia constituyente o procedente de los seres vivos.
Materias Volátiles

Pérdida de masa, corregida para tener en cuenta la humedad, medida mientras se calienta el carbón al abrigo del aire, en condiciones normalizadas.

\section{Minimización}

Proceso que conduce a prevenir la contaminación en la industria, generando menor cantidad de contaminantes (con menor carga o menos perjudiciales). Incluyen la adopción de medidas operativas y organizativas, técnicas y económicamente viables, de aquellas corrientes residuales que deban ser tratadas en la estructura actual, de modo que se cumpla con la legislación vigente y el objetivo final de la protección del ambiente.

\section{Nicho Ecológico}

Papel funcional que desempeña un organismo en el ecosistema.

\section{Nutriente}

Sustancia que un organismo animal o vegetal utiliza como fuente de energía o como constituyente de su engranaje metabólico.

\section{Orgánico}

Perteneciente o derivado de los organismos vivos.

\section{Organismo Patógeno}

Organismo que es capaz de causar enfermedades en plantas y animales.

\section{Ordenamiento del Paisaje}

Parte de los procesos de planificación de usos del suelo, que se ocupa de los valores físicos, biológicos, geológicos, estéticos, culturales, 
históricos y antropológicos, así como de las relaciones entre estos valores y los usos del suelo.

$\mathrm{pH}$

Concentración del ión hidrógeno en el agua. Se expresa la concentración de este ión como $\mathrm{pH}$, y se define como el logaritmo decimal cambiado de signo de la concentración de ión hidrógeno.

\section{Política Ambiental}

Conjunto de medidas que posee un mínimo de coherencia entre sí, tendiente a lograr el ordenamiento ambiental.

\section{Procesos Biológicos}

Aquel en que las bacterias y otros microorganismos descomponen los compuestos orgánicos complejos en otros más simples y estables.

\section{Producción Limpia}

Generación de productos de una manera sostenible, a partir de la utilización de materias primas renovables, no peligrosas y empleando energía de una manera eficiente, conservando a la vez la biodiversidad.

\section{Recursos Biológicos}

Son aquellos componentes de la biodiversidad que admiten un uso directo, indirecto o potencial para la humanidad.

\section{Recursos Renovables}

Recursos que están disponibles con distintos intervalos de tiempo. El empleo de las fuentes actuales no disminuye la disposición futura siempre que la tasa de consumo no exceda a la de generación.

\section{Restauración de Suelos}

Conjunto de actividades encaminadas a la recuperación de las propiedades de un suelo que por las circunstancias que fueran quedó degradado.

\section{Simbiosis}

Interrelación de dos o más individuos de distintas especies, en la que todos salen beneficiados.

\section{Sinergismo}

Fortalecimiento de los efectos esperados. Cuando el efecto resultante es el mayor que la suma de los efectos considerados independientemente.

\section{Suelo}

Parte externa de la corteza terrestre que es asiento de la vida, formada por la transformación de los minerales y la materia orgánica muerta.

\section{Tecnologías Limpias}

La tecnología más limpia, según la ONU "es un proceso de fabricación o una tecnología integrada en el proceso de producción, concebido para reducir, durante el propio proceso, la generación de residuos contaminan 


\section{BIBLIOGRAFÍA}

Fonnegra G., R., \& Jiménez R., S. L. (1999). Plantas medicinales aprobadas en Colombia. Medellín, Colombia: Universidad de Antioquia.

Michaud, E., Henry, S. J., Becker, B., Castleman, M., \& Hoffman, M. (2000). Guia completa de remedios naturales y medicinales. (R. Wild, Ed.) México: Diana.

Castro Restrepo, D., Díaz García, J. J., Serna Betancur, R., Martínez Tobón, M. D., Urrea, P. A., Muñoz Durango, K., et al. (2013). Cultivo y producción de plantas aromáticas y medicinales. (Universidad Católica de Oriente, Ed.) From

http://www.uco.edu.co/investigacion/fondoeditorial/libros/Docu ments/Libro\%20Plantas\%20Aromaticas\%202013.pdf

Fretes, F. (Mayo de 2010). Plantas medicinales y aromáticas una alternativa de producción comercial. (USAID, Ed.) From https://www.usaid.gov/sites/default/files/documents/1862/planta s_medicinales.pdf

Díaz, J. A. (Febrero de 2003). Informe Técnico. Caracterización del mercado colombiano de plantas medicinales y aromáticas. (M. d. Instituto Alexander von Humboldt, Ed.) From

http://repository.humboldt.org.co/bitstream/20.500.11761/31375 /1/243.pdf

Instituto de Investigaciones Agropecuarias. (2005). Agricultura orgánica principios y prácticas de producción. From http://biblioteca.inia.cl/medios/biblioteca/boletines/NR33207.pdf
Fondo Internacional de Desarrollo Agrícola (FIDA), Unidad Regional de Asistencia Técnica (RUTA), Centro Agronómico Tropical de Investigación y Enseñanza (CATIE), Organización de las Naciones Unidas para la Agricultura y la Alimentación (FAO). (Agosto de 2003). Agricultura Orgánica: una herramienta para el desarrollo rural sostenible y la reducción de la pobreza. From http://www.fao.org/3/a-at738s.pdf

Ministerio de Agricultura y Desarrollo Rural, República de Colombia. (n.d.). Reglamento para la producción primaria, procesamiento, empacado, etiquetado, almacenamiento, certificación, importación y comercialización de Productos Agropecuarios Ecológicos. From https://www.minagricultura.gov.co/tramitesservicios/Documents/Reglamento_para_la_produccion_Organica.p df

Fundación Manuel Mejía. (n.d.). (R. d. Ministerio de Agricultura y Desarrollo Rural, Ed.) From

http://datateca.unad.edu.co/contenidos/116001/Material_Unidad _l/agricultura_organica.pdf

Martínez Bernal, L. F., Bello Rodriguez, P. L., \& Castellanos Domínguez, O. F. (2012). Sostenibilidad y desarrollo : el valor agregado de la agricultura orgánica. (Universiad Nacional de Colombia, Ed.) From http://www.bdigital.unal.edu.co/7113/1/9789587612431.2012Version2.pdf 
Nuñez, R., \& Vatovac, A. (2006). La Huerta Orgánica. (USAID, The Nature Conservancy, , Ed.) From http://ecocosas.com/wp-

content/uploads/Biblioteca/perma/la\%20huerta\%20organika.pdf

Gutierrez, Cardozo, E. (Octubre de 2013). Sistema para la elaboración de huertas urbanas como autoabastecimiento alimenticio en los hogares vulnerables. From

https://repository.icesi.edu.co/biblioteca_digital/bitstream/10906/

76631/1/sistema_elaboracion_huertas.pdf

USAID, PERÚ, PDA; (Febrero de 2010). Manual para preparar abonos y biofermentos orgánicos. From

http://www.ruta.org/CDOC-

Deployment/documentos/Manual_para_preparar_abonos_y_biofe rmentos_org\%C3\%A1nicos.pdf

Corporación Educativa para el desarrollo Costarricense (CEDECO). (2005). Preparación y uso de abonos orgánicos sólidos y líquidos. From http://cedeco.or.cr/files/Abonos_organicos.pdf 